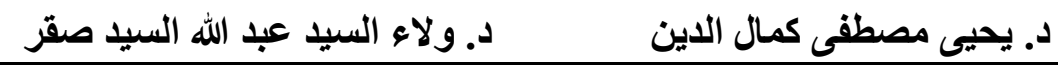

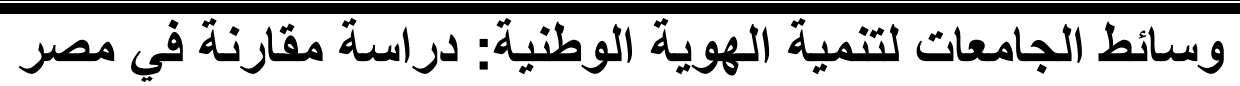

\title{
وفرنسا واليابان
}

إعداد

د. ولاء السيد عبد الله السيد صقر

د. يحيى مصطقى كمال الدين

أستاذ التربية المقارنة والإدارة التعليمية المساعد أستاذ التربية المقارنة والإدارة التعليمية المساعد

كلية التربية - جامعة عين شمس الآنس

كلية التربية - جامعة عين شمس والادرة

مقدمة البحث:

تُعد الحاجة إلى الانتماء من الحاجات الضرورية للنفس البشرية، فشعور الفرد

بانتمائه إلى جماعته التي يتشارك معها الطبائع و العادات، والقيم والاتجاهات، و التي يتواصل معها بلغة واحدة، ويجمعهم تاريخ مشترك يجعله أكثر استقرارا. إلا أن هذا الانتماء كظاهرة اجتماعية، يتأثر كغيره من الظواهر الأخرى بالتحولات المختلفة التي يشهذها المجتمع، ويُعد الثباب أثد المتأثرين بهذه التحولات؛ لأنهم بحسب طبيعتهم العُمرية، يُعدون الفئة الأكثر ميلاً للأفكار الغريبة والجديدة، والأشد انجذاباً للممارسات غير المألوفة، وهو ما يقودهم إلى الانسلاخ من تراثهم، والابتعاد عن قيم مجتمعهم،

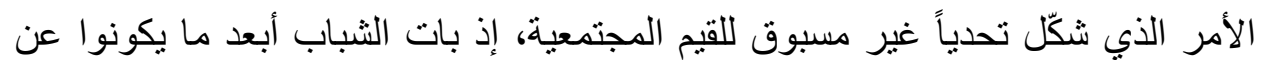

مجتمعاتهم، حتى وصل الأمر إلى تشتت هويتهر ومسخها. هذا وتتير نظريات علم الاجتماع إلى وجود ارتباط بين مفهوم الهُوية، والانتماء

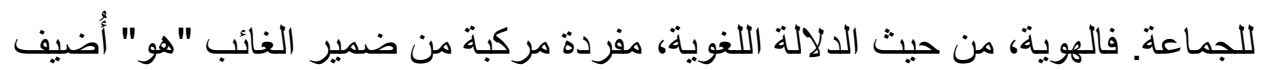
إليه ياء النسبة، لتدل مجتمعة على كينونة الشخص، أو الثيء بصورته الواقعية

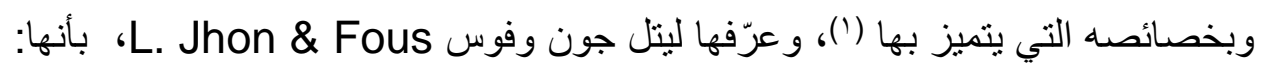
تللك الرموز التي تُميز انتماء الفرد لمجموعة معينة، مثل: الزي، و المقتنيات العامة، والعبارات التي يستخدمها للتعريف بنفسه، أو الأشياء الأخرى، والمفاهيم الدارجة بين أفر اد المجموعة للتعبير عن الأشياء. (广)

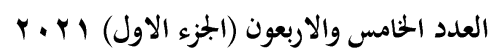

مجلة كلية التربية- جامعة عين شمس 
أثر برنامج إثرائي قائم على معايير العلوم اللجيل القادم (NGSS) في تنمية مهارات القرن الحادي والعشرين

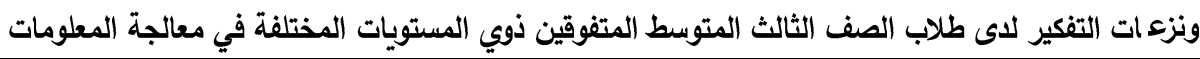
وير اها آخرون بأنها مجموعة الخصائص، و المميزات اللغوية و العقدية والعرقية و الأخلاقية و التاريخية والجغر افية، بالإضافة إلى العادات، و التقاليد، و السلوكيات التي تطبع شخصية الفرد، والجماعة، والأمة بطابع معين تتفرد به عن باقي الأمم، بحيث تُشكل مرجعيتها المعبرة عن ثقافتها، ودينها، وحضارتها. (r) ونظر الأن الهوية تجمع في طيّاتها عناصر عدة، هي القرابة، والولاء، والانتماء للأرض، و لأن هذه العناصر قد تعكس الثقافة الفردية لمجتمعات متباينة عن بعضها داخل الوطن، ظهرت الحاجة إلى مفهوم جامع يمثل أبناء الوطن الواحد، ويعبر عن هذه الثقافات المتباينة على ذات الأرض بعيداً عن الانتماءات المختلفة لهويات فرعية، وعليه فقد ظهر مفهوم الهوية الوطنية، ليشير إلى الهوية الجمعية التي تعبر عن أبناء الوطن

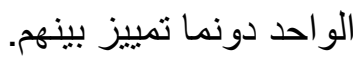

هذا ويقتضي بناء الهوية الوطنية أن تقوم مؤسسات المجتمع بكافة أثكالها بالعمل على تتمية هذا المفهوم، وترسيخه في نفوس أبنائه، والتأكيد عليه، إلا أن الدور الأبرز والأكثر تأثثراً، هو للمؤسسات التربوية. إذ يثير أندرسون Anderson في دراسة له إلى أن مؤسسات التربية بما تملكه من إمكانات قادرة على تشكيل الطريقة التي يُفكر بها أبناء المجتمع، فان لها الدور البارز في ترسيخ الهوية الوطنية وتأكيدها، وهو ما ينعكس أثره على تكوين أجيال أكثر تمسكاً بهويتها، فالتربية هي التي تشكل صورة المجتمع في لهوري الأذهان، بما يعمل على توجيه الطاقات نحو خدمة الهوية المشتركة. ويؤكد ليندوال Lindwal ذللك بقوله إن التربية تحوز سلطة المعرفة التي يدرك الطلبة من خلالها أهمية هويتهم، ومكانتها، و التحديات التي تعوقها، وكيفية مواجنتها.(؛) و الجامعة، كمؤسسة تربوية إضافة إلى كونها مؤسسة تعليمية، يقع على عاتقها تعزيز الهُوية الوطنية لطلبتها، ونظراً لأن الطلبة في هذه الفئة العمرية يكونون أكثر عرضة لحملات التشوية والتغريب، لما تبثه وسائل الاعلام و التو اصل الاجتماعي من 
د. ولاء السيد عبد الله السيد صقر د. يحيى مصطفى كمال الدين

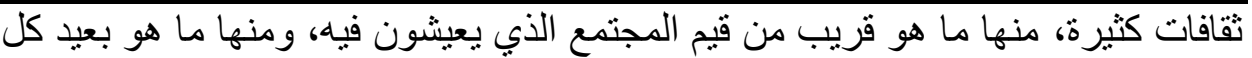

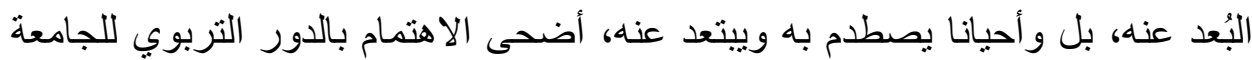
أكثر ضرورة من أي وقت مضى. ومن الجدير بالذكر في هذا السياق، أن الهدف الاستراتيجي للجامعات في العالم، هو تكوين مو اطنين صالحين لديهم مشاركة فاعلة، ورؤية صحيحة، واتجاهات إيجابية نحو البيئة المحلية، والعالم الخارجي، إلى جانب إكسابهم لمفاهيم المعرفة والبحث العلمي.

و هو الأمر الذي أكدت عليه رؤى العديد من الجامعات العربية وبر امجها الدراسية ومقرراتها، حيث قضية الهوية الوطنية واحدة من أبرز القضايا التي وردت في الخطابات الرسمية للجامعات العربية. (0) وفي مصر أكدت وزارة التعليم العالي في استراتيجيتها لتحقيق خطة التنمية

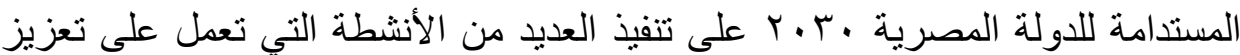
الهوية الوطنية للثباب الجامعي من بينها: (†) - إقامة ندوات لتنمية الهوية الوطنية لدى الثباب الجامعي تدور حول عدد من القضايا منها: استر اتيجية الأمن القومي، ومعنى الدولة ومقوماتها، وحروب الجيل الرابع، وماذا يحدث في سيناء، و العالم الافتراضي وحروب الثائعات، والأمن المائي وترشيد استهلاك المياه، و المؤامر ات الخارجية. - - تنظيم المهرجانات الفنية مثل مهرجان حكاية نصر، و الذي استهدف نشر الحقائق النتاريخية حول حرب أكتوبر بح9 المجيدة. إقامة المسابقات و الأنشطة الفنية والندو ات التتقيفية التي تسلط الضوء على حرب أكتوبر بالجامعات و المعاهد المصرية. تتفيذ نماذج المحاكاة بالجامعة (الأمم المتحدة- مجلس الوزر اء- مجلس النواب) ممارسة العملية السياسية من خلال انتخابات الاتحادات الطلابية.

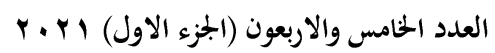


أثر برنامج إثرائي قائم على معايير العلوم اللجيل القادم (NGSS) في تنمية مهارات القرن الحادي والعشرين ونزء ات التفكير لاى طلاب الصف الثالث المتوسط المتفوقين ذوي المستويات المختلفة في معالجة المعلومات

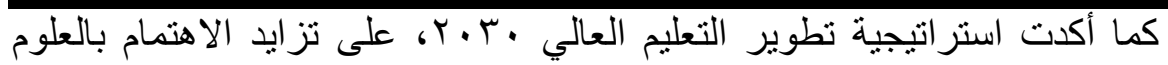
الإنسانية للحفاظ على الهوية الثقافية المصرية، مع الوضع في الاعتبار تعديل بعض له له توجهات العلوم الإنسانية للتوعية والتأكيد على دور الجامعات في تعزيز قضية الانتماء و المو اطنة لاى طلاب الجامعات المصرية. (7)

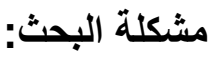

على الرغم مما تمت الإشارة إلية من أن الهوية الوطنية تشكل لبنة أساسية في كيان أي مجتمع، وأن الدول على اختلاف توجهاتها تبذل جهوداً كبيرة لتنميتها، وتعزيز ها لاى مواطنيها، لتجنيبهم أن يكونوا فريسة سهلة، ولقمة سائغة لما يمر بهم من متغيرات، ليس المجتمع المصري كغيره من المجتمعات العربية، أو العالمية بمنأى عن

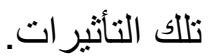
إلا أن المتتبع لمنظومة التعليم الجامعي في الوطن العربي سيلحظ ما تعانيه معظم الجامعات من ظواهر، وسلوكيات تربوية، واجتماعية غير مقبولة، أفرزتها متغيرات عدة، وصاحبها نأثير ات سلبية ثقافية، واجنماعية، كان من نتائجها ظهور اتجاهات، وقيم غريبة على ثقافتنا، انعكست سلباً على التكوين الثقافي والاجتماعي، ومن ثمّ هؤية الثباب الجامعي، الأمر الذي فسره الكثيرون بأنه يُعبر عن إخفاق الجامعة، كمؤسسة تربوية في

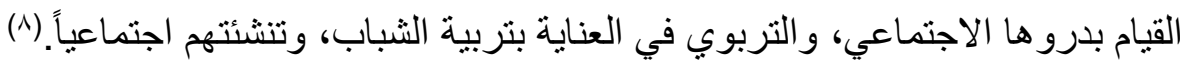
و على اعتبار أن المجتمع المصري جزءً من المجتمع العربي، يُعاني هو الآخر من ذات المشكلات التي يعاني منها المجتمع العربي ككل، بل ويعاني الثباب المصري من محاو لات غزو عقلياتهم ثقافيا، حيث كثف أحد التقارير الرسمية الصادر عن وزارة الاتصالات وتكنولوجيا المعلومات، أن مصر تحتل المرتبة الأولى على مستوى العالم العربي و الـ ـ ا على المستوى العالمي، في استخدام مواطنيها للفيس بوك(9)، الأمر الذي مهد السبيل لاحتلال الثقافة الهجينة لعقلية الثباب المصري، نظراً لما يطلعون عليه من 


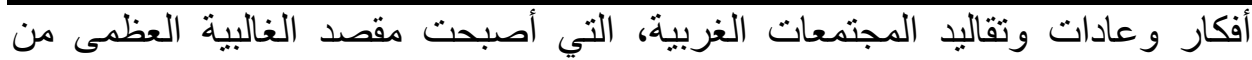
الثباب، و لاسيما الثباب المصري. هذا إضافة إلى انتشار الكثير من الظواهر السلبية الاجتماعية منها والأخلاقية بين الثباب الجامعي، من أهمها و أكثرها تأثنراً على التماسك الوطني ظاهرة تدني قيم الانتماء والولاء، الأمر الذي يمكن نعزوه إلى غزو الثقافات الغربية لعقليات الثباب،

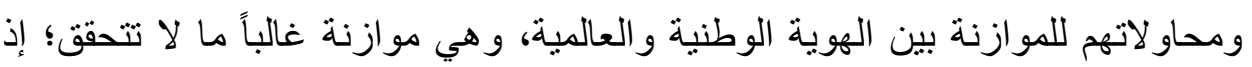
تميل الأمور غالباً إلى كفة الهوية العالمية، الأمر الذي أثر سلباً على الثباب المصري، لهوله

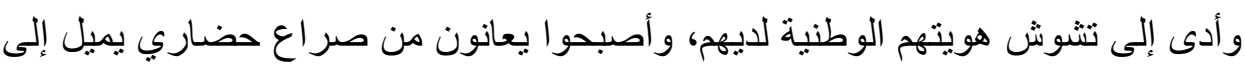
تفضيل الثقافات الغربية عن المحلية، ومن ثم يتأثر انتماء الثباب المصري للمجتمع الأم

سلباً. (·)

و على الرغم مما تبذله مصر في سبيل تعزيز الهوية الوطنية لدى أبنائها من طلاب الجامعات إلا أن هناك بعض المعوقات التي تحول دون القيام بذلك بشكل أكثر فعالية ومن هذه المعوقات:

- محدودية وجود مناهج أو برامج أو مقررات دراسية جامعية لتعليم المواطنة أو تقويمها، وذللك على الرغم من الأهمية البالغة لدور الجامعة في تربية

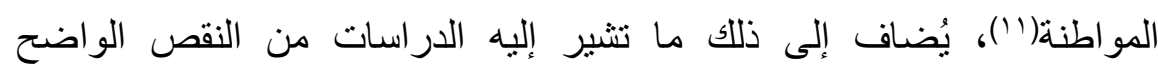
و الملحوظ في معارف الثباب حول واجبات الانتماء والمواطنة، و انتشار حالات

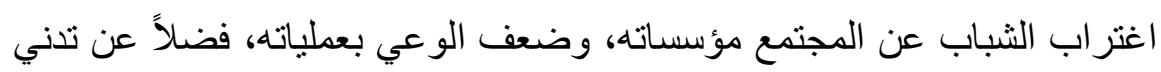
البرامج الدراسية التي تهنم بتعليم الحقوق والواجبات والمسئوليات المدنية في الجامعة والمجتمع(r')، و ومن ثم لا تقدم الجامعة المقررات والأفكار التي من شأنها تعزيز أفكار الطلاب وانتمائهم المنشودين في ظل الغزو التقافي الذى يستهدف عقليات الثباب المصري. 
أثر برنامج إثرائي قائم على معايير العلوم اللجيل القادم (NGSS) في تنمية مهارات القرن الحادي والعشرين ونزء ات التفكير لاى طلاب الصف الثالث المتوسط المتفوقين ذوي المستويات المختلفة في معالجة المعلومات - ما تشهده المنطقة العربية من صراعات طائفية ومذهبية وحروب أهلية يؤشر بوجود أزمة عميقة في علاقة المواطن بالدولة، وما يعنيه ذلك من فنثل الدول العربية بشكل عام، ومن بينها مصر، في بناء هوية وطنية جامعة لكل من يعيش على أرضها(r')، الأمر الذي جعل الثباب المصري عرضة للتبار ات الهدامة التي تسعى إلى زعزعة هويتهم و انتمائهم للوطن، خاصة وأن وسائل الاعلام لا تقوم

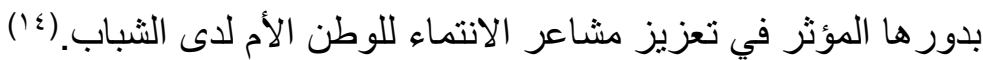
ضعف الاهتمام بقضايا المواطنة والهوية الوطنية؛ إذ ماز الت قضية المواطنة، قضية عابرة في أنشطة وممارسات الجامعات العربية بشكل عام، والجامعات المصرية على وجه الخصوص، فلم تتجاوز قضية المواطنة والهوية الوطنية مجرد كونها موضوعاً للبحث والدرس(10)، كما قد اختلف الاهتمام بقضايا المواطنة من لن جامعة مصرية لأخرى، فبعض الجامعات تفرض على الطلاب في هذا الصدد مقررات اجبارية، والبعض الآخر يعتبر ها اختيارية، ولا تحتسب ضمن المجموع الكلي للمقررات التي يدرسها الطلاب، ولا تحتسب ضمن التقدير العام النهائي لهم(1)، الأمر الذي جعل جهود ترسيخ قيم المواطنة والانتماء لدى الطلاب الجامعيين المصريين، جهوداً مبعثرة، تفتقر إلى وجود الخطط الثابتة والموحدة، التي تضمن بناء قيم المو اطنة والانتماء داخل عقول الثباب الجامعي المصري. - تفشي وانتشار التدريس باللغات الأجنبية في الجامعات المصرية، والاهتمام بنشر الثقافات الأجنبية، واستقطاب انتماء الطلاب لتلك الثقافات الأجنبية، الأمر الذي له يسهم في ضعف انتماء الطلاب لهوياتهم، وانجذابهم نحو الثقافات الأجنبية في مقابل الثقافة العربية التي ينتمون إليها فعليا.('ا') الأمر الذي له الأثر السلبي على له انتماء طلابها للهوية والثقافة العربية، ذلك أن اللغة هي المكون الرئيس للتقافة الأم، و المدعم الأساسي للانتماء للمجتمع الأم. (^) 


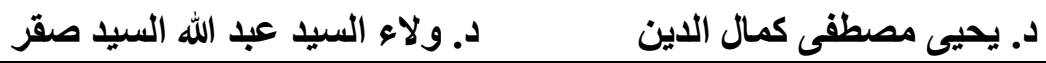
ومن هنا تتلخص مشكلة البحث في السؤ ال الرئيس التالي: دهمئ ولاء

كيف يمكن تطوير وسائط الجامعات المصرية لتمية الهوية الوطنية لدى طلابها،

في ضو غ خبر ات كل من فرنسا و اليابان؟

ويتفرع من السؤال الرئيس السابق الأسئلة الفرعية التالية:

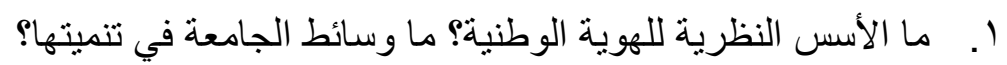

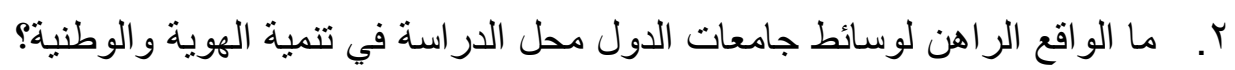

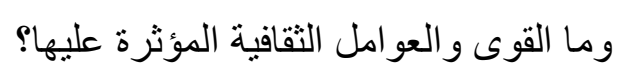

r. ما أوجه التشابه والاختلاف لوسائط جامعات الدول محل الدراسة في تتمية الهوية

الوطنية؛

ع. ما الإجر اءات المقترحة لتطوير وسائط الجامعات المصرية لتنمية الهوية الوطنية لدى طلابها في ضوء خبرات الجامعات الفرنسية واليابانية، وبما يتلاءم مع ظروف المجتمع المصري؟

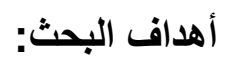

$$
\text { هدف البحث إلى تحقيق ما يلي: }
$$

1. الوقوف على الأسس النظرية للهوية الوطنية ووسائط الجامعة في تنميتها. Y. التعرف على الو اقع الراهن لوسائط جامعات الدول محل الدراسة في تنمية الهوية الوطنية و القوى و العوامل الثقافية المؤثرة عليها.

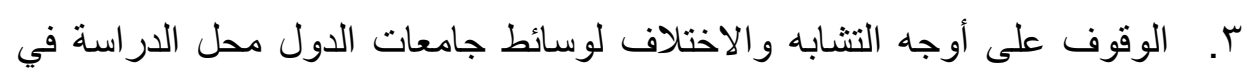
تنمية الهوية الوطنية. ع. التوصل إلى عدد من الإجراءات المقترحة لتطوير وسائط الجامعات المصرية في تتمية الهوية الوطنية لدى طلابها بالاستفادة من خبرات الجامعات الفرنسية و اليابانية، وبما يتلاءم مع ظروف المجتمع المصري.

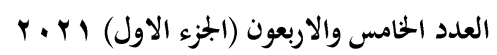

(325)
مجلة كلية التربية- جامعة عين شمس 
أثر برنامج إثرائي قائم على معايير العلوم للجيل القادم (NGSS) في تنمية مهارات القرن الحادي والعشرين

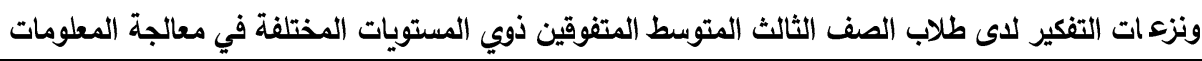
حدود البحث:

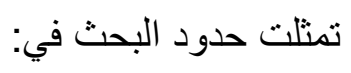

• الحد المكاني: اقتصر الباحثان على تجربتي كل من فرنسا واليابان، باعتبار هما يعبران عن ثقافتين مختلفتين إحداهما أوروبية والأخرى أسيوية، كما أن كلا التجربتين لهما تاريخ طويل في تأكيد الهوية الوطنية والحفاظ عليها، فهما دولتان اهتمتا بتدعيم الهوية الوطنية لديهما من خلال الاعنزاز باللغتين الفرنسية

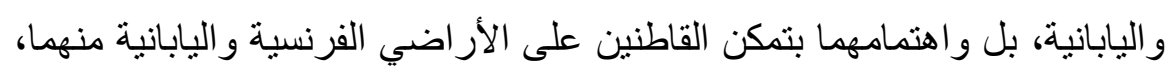

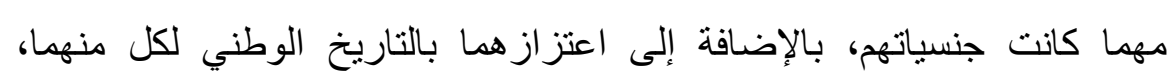
وتعريف الآخرين به، كنوع من الاعتزاز بالتاريخ الوطني للبلدين، وتقدير التراث الثقافي لكل منهما.

الحد المجالي: اقتصر الباحثان على خبرة الجامعات في تنمية الهوية الوطنية لطلابها، بالوقوف على وسائط الجامعات من خلال تعزيز تعلم اللغة القومية و التعليم بها، و المقررات الدراسية، و الأنشطة الطلابية الجامعية، لما لهذه الجوانب لهن الثلاث من أثر في تعزيز مقومات الهوية الوطنية والمتمثلة في اللغة والمعتقدات

$$
\text { مصطلحات البحث: }
$$

تناول البحث الحالي عدد من المصطلحات، يمكن إيضاحهم من خلال العرض التالي:

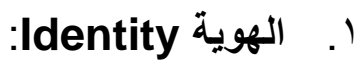

الهوية: هي حقيقة الثيء، وصفاته التي يتميز بها عن غيره، وتظهر بها شخصيته، وأهم تللك المميزات: الدين، و اللغة، و القومية، والتراث، و على هذا تمثل الهوية الضمير الجمعي لأي تكتل بشري ومحتوى لهذا الضمبر في الآن نفسه بما يشمله من

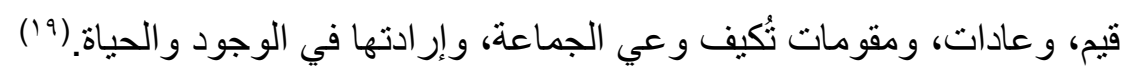


د. ولاء السيد عبد الله السيد صقر د. ئحيى مصطفى كمال الدين

الهوية: هي و عاء الضمير الجمعي لأي تكتل بشري، بما يشمله من قيم، و عادات، ومقومات تكيف وعي الجماعة وإرادتها في الوجود و الحياة داخل نطاق الحفاظ على لى لئ كيانها (·r)، حيث يجمع الباحثين على أنه لا وجود لشعب دون هوية يعبر من خلالها عن

الهوية مشتقة من "هو"، فهي عملية تمييز الفرد لنفسه عن غيره من سماته،

فالهوية أن يعرف الثخص جذوره، وميوله، ويؤكد على انتمائه لهذه الجذور. (r) كما تعرف بأنها الإجابة عن السؤال الفلسفي الذي يتعلق بماهية القيم التي تميز

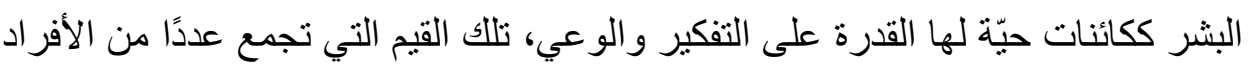

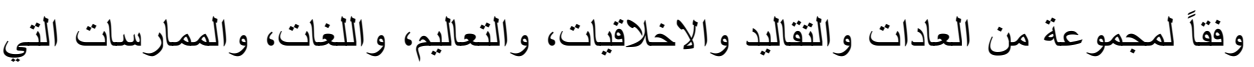
تتنمي لمجتمع دون غيره، فتجعل لهؤلاء الأفر اد شخصية تختلف عن شخصية آخرين من

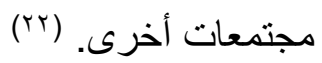

كما عرفت بأنها مجموعة السمات والقواسم المشتركة التي يؤمن ويتمسك بها جماعة من البشر، يشتركون معاً في التاريخ، والعادات والتقاليد والميراث الثقافي، و اللغة، و العادات و التقاليد، و التعاليم، و المبادئ التي يرتضيها المجتمع الذي ينتمون إليه،

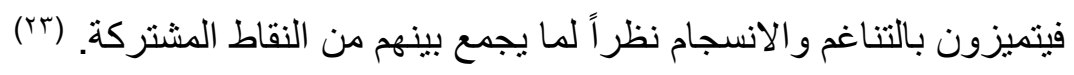

\section{r. National Identity . الهوية الوطنية}

هي الانتماء للوطن، و هو ما يعني ممارسة الفرد للقيم والأخلاق التي تعكس أفعالاً

تعبر عن حب الوطن و الدفاع عنه، و الالتز ام بأنظمته، واحتر ام قو انينه. (ع)

وهي الشعور القومي والانتماء الفعلي لأمة من الأمم أو لشعب من الثعوب. (ro) كما أنها ذلك الكيان الذي يتم بناؤه وتناقله من خلال التواصل اللفظي، عبر سرد الثقافة

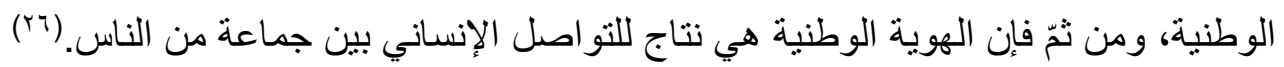
وتعرف الهوية الوطنية أيضاً بأنها ذلك الثعور الذي يجعل الأمة وحدة متماسكة

متمثلا في تقاليدها وثقافتها ولغتها المميزة. (rY)

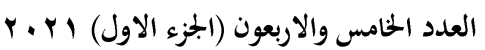

(327)
مجلة كلية التربية- جامعة عين شمس 
أثر برنامج إثرائي قائم على معايير العلوم للجيل القادم (NGSS) في تنمية مهارات القرن الحادي والعشرين

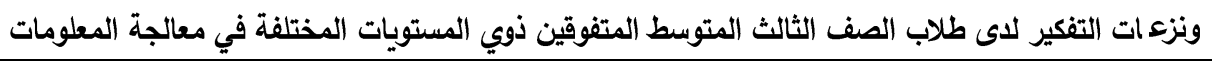
ويتضح مما سبق في تعريف الهوية الوطنية أنها مفهوم يحوي ما يلي: - سلوك يعبر عن الانتماء للوطن من خلال الالنزام بالأخلاق والقبم، والأنظمة و القو انين و الذود عنه. - شعور بالانتماء لجماعة من الناس يتشاركون فيما بينهم من عادات وقيم وأخلاقيات وأنظمة حياة، وتقاليد ولغة. - نظام مكون من مدخلات بشرية وقيمية ونظامية تظهر عملياته في شكل سلوكيات تعبر عن تفاعل تلك المدخلات، لتفرز مخرجات تظهر في شكل التزام بالقوانين والأنظمة، واحتر ام للعادات و القيم والتقاليد، وذلك من أجل بقاء الجامعة التي يعبر عنها الوطن. نتيجة لذلك تصبح الهوية الوطنية معبرة عن الانتظام العام في المجتمع وفق مبدأ أخلاقي ضمن نسيج مجتمعي متماسك قائم على التعاون، والمحبة، واحترام العادات،

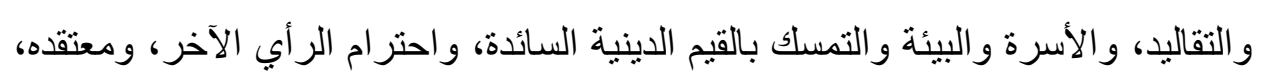
ووجهة نظره.

\section{منهج البحث وخطواته:}

اتبع البحث المنهج المقارن Comparative Methodology، على اعتبار أنه أنسب المناهج التي تتلاءم وطبيعة البحث الحالي، بغرض المقارنة بين دول المقارنة

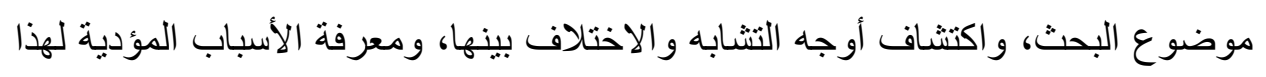
التشابه والاختلاف، وتستتد المعالجة المنهجية للمنهج المقارن على البعد التاريخي، الوصفي، والتحليلي الثقافي، والمقارن التفسيري، وتتلخص الخطوات المنهجية النظرية

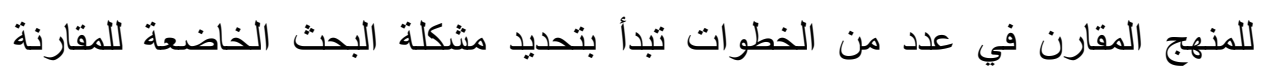

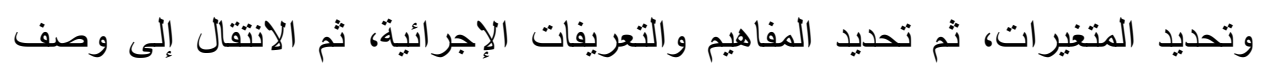
وتحليل الظاهرة محل البحث في ضوء القوى والعوامل الثقافية المؤثرة فيها، يلي ذلك الكئل

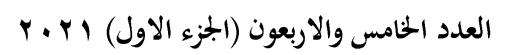

(328)
مجلة كلية التربية- جامعة عين شمس 
د. ولاء السيد عبد الله السيا صقر د. يحيى مصطقى كمال الدين

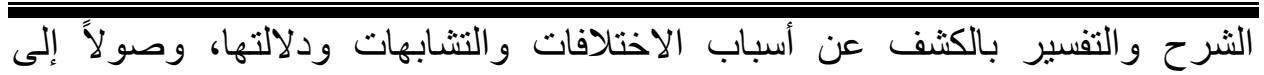
الإجر اءات المقترحة لتفعيل الظاهرة بما يتناسب مع و اقع بيئة الظاهرة. (^^) و عليه سار البحث وفقاً للأقسام التالية:

- القسم الأول: الهوية الوطنية ووسائط الجامعات في تنميتها (إطار نظري) - القسم الثاني: الواقع الراهن لوسائط الجامعات المصرية في تتمية الهوية الوطنية و القوى و العو امل الثقافية المؤثرة عليها. - القسم الثالث: الو اقع الر اهن لوسائط الجامعات الفرنسية و اليابانية في تنمية الهوية الوطنية و القوى و العو امل الثقافية المؤثرة عليهما. - القسم الر ابع: تحليل مقارن تفسيري لوسائط جامعات الدول محل الدر اسة في تتمية الهوية الوطنية لدى طلابها. - القسم الخامس: الإجراءات المقترحة لتنمية وسائط الجامعات المصرية في تنمية الهوية الوطنية بالاستفادة بخبرات الدول محل الدراسة، وبما يتلاءم مع ظرف

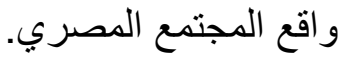

\section{القسم الأول: الهوية الوطنية ووسائط الجامعات في تنميتها (إطار نظري)}

تناول هذا الإطار استعراض الأدبيات والدراسات التربوية التي تناولت مفهوم الهوية الوطنية، ومقوماتها ووظائفها، كما يتناول خبرة الجامعات المعاصرة في تنمية الهوية الوطنية لطلابها، وذلك وفقاً للمحاور التالية: أولاً: إطار مفاهيمي:

يتناول الإطار المفاهيمي الوقوف على ماهية الهوية الوطنية بتحديد مقوماتها

$$
\text { و المفاهيم ذات العلاقة }
$$


أثر برنامج إثرائي قائم على معايير العلوم للجيل القادم (NGSS) في تنمية مهارات القرن الحادي والعشرين

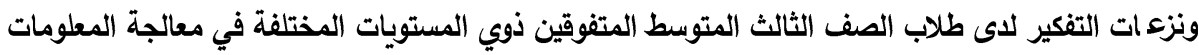

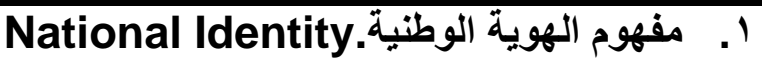

للوقوف على ماهية الهوية الوطنية بشكل دقيق، لابد من الوقوف أولا على مفهوم

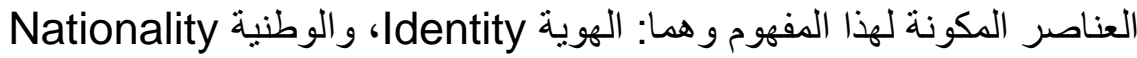
الهوية اصطلاحاً: هي الحقيقة المطلقة المشتملة على الحقائق اشتمال النواة على الثجرة، كما أن الهوية تُطلق على ثلاثة معان هي: التشخيص، و الثخص نفسه، و الوجود

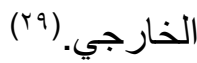
وهناك من حاول أن يعمق ذللك المعنى بقوله: "تُعبر الهوية عن حقيقة الثيء المطلقة المشتملة على صفاته الجوهرية التي تميزه عن غيره، وبالتالي فالهوية هي: ثقافة الشعب، أو القدر الثابت الجوهري و المشترك من السمات، والقسمات العامة التي تميز حضارته عن غير ها من الحضار ات".(·) وبناء على ما سبق يمكن القول: إن هوية أي إنسان هي الأصول التكوينية له، و الخصائص التي تمبزه عن غيره، وتجعله عضواً في جماعة من الناس بجمعه بها تلك الك الأصول السمات، والتي هي غالبا الدين المشترك و اللغة القومية والتاريخ الواحد و التر اث الثقافي من عادات وتقاليد وقيم. أما المواطنة فهي: صفة المواطن التي تُحدد حقوقه وواجباته الوطنية، وتتميز بنوع خاص من و لاء المواطن لوطنه وخدمته في أوقات السلم و الحرب، و التعاون مع المواطنين الآخرين عن طريق العمل المؤسساتي والفردي الرسمي والتطوعي، في تحقيق الأهداف التي يصبوا إليها الجميع، وتتوحد من أجلها الجهود، وترسم الخطط وتوضع الموازنات. (r) (r) و المو اطنة بمفهومها الواسع هي: تللك الرابطة التي تجمع الفرد بالمكان الذي يقيم فيه، وتربطه به أرضاً، وتاريخاً، وثقافة؛ لذا يُعتبر شعوره المنزايد بالمواطنة من بن التوجهات التي يُستدل عليها بمو اقفه تجاه القانون و النظام السائد في الدولة، ومو اقفه تجاه 
د. ولاء السيد عبد الله السيد صقر د. يحيى مصطفى كمال الدين

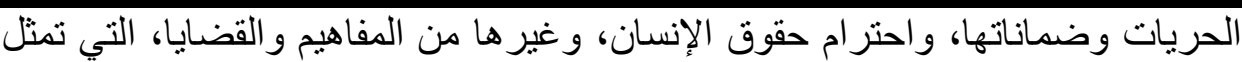
المرتكزات الأساسية للمواطنة بأي مجتمع، مهما تباينت منطلقاته الفكرية، أو الو

الفلسفية. (rr)

كما تُعرف بأنها علامة الفرد الذي يعرف حقوقه، ومسئولياته تجاه مجتمعه الذي يعيش فيه، ويشارك بفاعلية في صنع قرار اته وحل مشكلاته، وتعاونه وعمله الجماعي

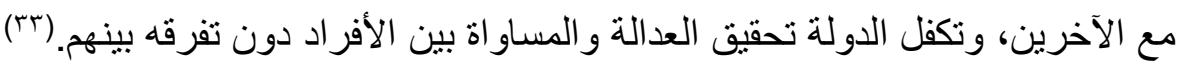
و المو اطنة هي: حب الفرد لوطنه، و انتماؤه إليه، و التزامه بقيمه وقو انينه، و التفاني

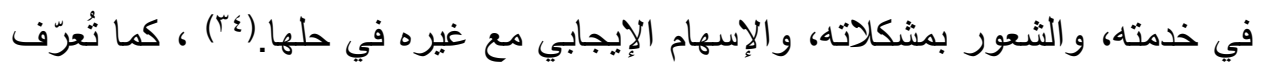
المواطنة بأنها: الجانب السلوكي الظاهر، و الممارسات الحية التي تعكس حقوق الفرد، وواجباته تجاه مجتمعه ووطنه، و التزامه بمبادئ المجتمع، وقيمه، وقوانينه، ومشاركته

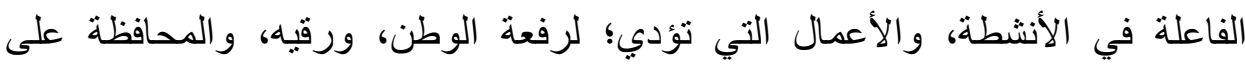
مكتسباته. (ro) و الناظر إلى مفهوم المواطنة يلحظ أنه يثير إلى عدة أمور، هي: - - انها ارتباط الفرد بجماعة من الناس يجمع بينهم أمور مشتركة، كالأرض، و التاريخ. - أنها تعمل على التزام الفرد، وتقيده بالنظم، و القوانين، و القواعد العامة السائدة في المجتمع. - - أنها تعبر عن الدور الإيجابي الذي يقوم به الفرد تجاه مجتمعه بالمشاركة في كل ما يؤدي لرفعة الوطن، ورقيه، و الحفاظ عليه. لذا فإنه عند الربط بين مفهومي الهوية و المواطنة، يمكن القول بأن الهوية الوطنية هي: تلك الحالة الثعورية، والموقف الاجتماعي الذي يستشعر فيه الفرد ذاته بانتمائه إلى بـ جماعة من الناس، تربطه بهم أمور مشتركة تتباين تأثثر اتها، ومدى وضوحها من مجتمع لآخر، إلا أنها تلتقي جميعاً حول ما يمارسونه من عادات، وما يلتزمون به من قيم 
أثر برنامج إثرائي قائم على معايير العلوم للجيل القادم (NGSS) في تنمية مهارات القرن الحادي وإلعشرين ونزء ات التفكير لاى طلاب الصف الثالث المتوسط المتفوقين ذوي المستويات المختلفة في معالجة المعلومات وسلوكيات، وما يتو اصلون به من لغة مشتركة، ونتاريخ واحد، الأمر الذي يدفعه بشكل تلقائي إلى الحفاظ على ذلك الكيان المشترك؛ لما بستشعره من الإحساس بالأمان في البقاء معاه، بل وينقل هذا الثعور ، وتلك الممارسات إلى أبنائه بما يعمل على إعادة إنتاج هذا الكيان جيلاً بعد جيل. ولذا نلحظ أن الفرد عندما يتشبع بقيم المجتمع الذي يعيش فيه، ويمارس السلوكيات التي يرتضيها مجتمعه، ويبذل جهذه ونفسه من أجل الحفاظ على هذا المجتمع، ولا يشعر بالحرج عندما يتكلم بلغته ويدين بمعتقده، ويفخر عندما يتكلم عن تاريخه، و انجاز اته، و انكسار اته يكون بذللك محققاً للمعنى العملي للوطنية وهويتها. وبتحليل مفهوم الهوية الوطنية، يمكن استنتاج عدد من الملاحظات هي: (זّ) - أن الهوية الوطنية تعبر عن مجموعة من الملامح الثقافية الخاصة بجماعة من الناس تميز ها عن غير ها من الجماعات. - - - أن هناك علاقة بين ثقافة المجتمع وهويته؛ فالثقافة هي التي تثكل الهوية، وهي التي تعطي الاسم والمعنى والصورة للمجتمع، أي هي التي تميز المجتمع عن غيره.

- أن تكوّن الهوية الوطنية وتتشكل عبر الزمن، كمثل الجبال الراسية التي تتشكل من ترسيب الحجارة عبر الزمن، وكذلك هوية الوطن التي تتكون كرقائق أو طبقات بعضها فوق بعض بحيث تشكل النسيج الذي يربط الهوية الفردية بالجماعية، وكذلك بالهوية الوطنية. - - - أن الهوية الوطنية ذات طابع ديناميكي في تشكلها؛ فهي ليست ثابتة و أبدية، ولكنها تشهد عمليات تحول وتغير عبر الزمن نتيجة للتحولات العديدة التي تمر بالمجتمع. 
في ضوء التحليل السابق لمفهوم الهوية الوطنية، يلاحظ أن هنالك ثمة تشابك وليس اثتباك بين مفهوم الهوية الوطنية وعدد من المفاهيم مثل مفهومي الثخصية الوطنية و الثقافة الوطنية.

ومن ثم تعرف الثخصية الوطنية National Character بأنها الخصائص الثقافية الخاصة أو المميزة لأمة أو مجموعة عرقية معينة. (rYr) كما يستخدم مصطلح "الثخصية الوطنية" لوصف الخصائص الدائمة، و أنماط الحياة السائدة بين سكان دولة أو أو الو إقليم معين والمميزة لهم عن غيرهم في صورة سلوكيات عامة يمارسونها، ويُنظر إلى هذه السلوكيات باعتبار ها مميزة للشخصية الوطنية، دون الإشارة إلى أنماط الثخصية المختلفة للأفر اد الذين يمارسونها؛ ذلك أن هذا السلوك يمكن اعتباره مدفوعًا بآليات نفسية أساسية مميزة لشعب معين. (r^)

كما تثير الثخصية الوطنية إلى خصائص و أنماطٍ شخصيةٍ وظيفية، تعد نموذجًا أوليًا يجمع بين الأعضاء الر اشدين في المجتمع، وذلك على افتراض أن جميع أفراد هذا المجتمع تقريبًا يتصرفون وفقًا للمعايير المحددة لمجتمعهم. (ra) بمعنى آخر، تعبر الثخصية الوطنية عن مجموع العادات والاتجاهات والرغبات و الميول والآراء ووجهات النظر والدوافع والمعايير والمعتقدات و الأفكار والآمال

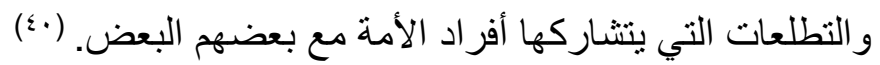

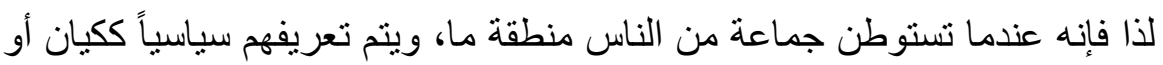
جماعة منظمة، فإن الخصائص المميزة لهم تؤخذ بعين الاعتبار عند تعريف الثخصية الوطنية لهم، وجدير بالذكر أن تلك الخصائص تخضع لتأثير التاريخ والنظام القانوني. وهو ما يتفق مع ما أنثار إليه هانز كون H. Koun، بأن الحياة في منطقة مشتركة،

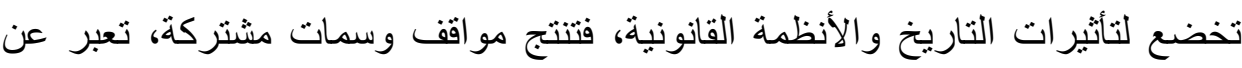

(الشخية الوطنية.(1)

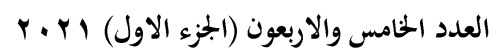

مجلة كلية التربية- جامعة عين شمس 
أثر برنامج إثرائي قائم على معايير العلوم اللجيل القادم (NGSS) في تنمية مهارات القرن الحادي والعشرين

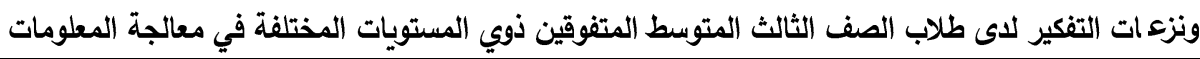

لذا فإنه يمكن القول بأن الثخصية الوطنية لجماعة من الناس، هي في مجملها السلوكيات المميزة لهذه الجماعة، والتي تتجسد في صورة يمارسونه من عادات، وما يتبنونه من اتجاهات، وما يحركه من رغبات وميول ودوافع، وما يوجهه من معايير ومعتقدات و أفكار ، وما يحلمون به من تطلعات يتشاركونها فيما بينهم. أما الثقافة الوطنية National Culture فتعرف بأنها مجموعة القواعد والسلوكيات

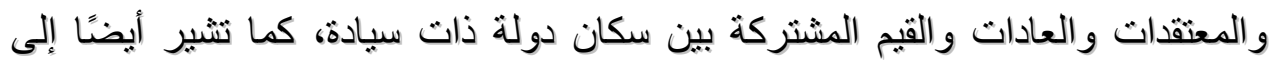
خصائص محددة مثل اللغة و الدين و الهوية العرقية والتاريخ و التقاليد الثقافية. (זء) وتعرف أيضا بأنها هي مزيج من الرموز والمعتقدات والمصنوعات اليدوية النموذجية

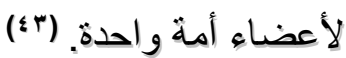
وبرؤية تحليلية للففاهيم الثلاثة: الهوية الوطنية والثخصية الوطنية والثقافة الوطنية، سنجد أنها مفاهيم متضمنة في بعضها البعض، حيث عُرّفت الثخصية الوطنية على أنها الخصائص الثقافية المميزة لجماعة من الناس، وعُرّفت الثقافة الوطنية بأنها مجموعة القو اعد و السلوكيات و المعتقدات الحاكمة والمشتركة بين سكان دولة واحدة، وتلك العادات و السلوكيات وغيرها مما تم ذكره، هي في ذات الوقت الملامح والضوابط التي تحدد الثخصية الوطنية لمجموعة من الناس، الأمر الذي يجعل كلا من مفهومي الثخصية الوطنية والثقافية الوطنية مفهومين متشابكين. ولما كانت الهوية الوطنية تتشكل عبر الزمن من خلال مجموعة السلوكيات والعادات المميزة لمجموعة الناس القاطنين فوق أرض واحدة، يجمعهم لغة وتاريخ وتراث مشترك، و الذي يعبر في مجمله عن المخزون الثقافي لهذه المجموعة، فإنه يمكن القول بأن الثقافة الوطنية هي جزء لا يتجزأ من الهوية الوطنية، ذلك أن الثقافة هي التي نشكل الهوية وتعطي المعنى والصورة للمجتمع، وتحدد الثخصية التي تميز المجتمع عن غيره. 
تتضح طبيعة الهوية الوطنية من خلال الوقوف على مقوماتها ووظائفها، وذلك على

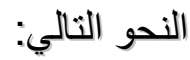

\section{1. مقومات الهوية الوطنية:}

تتعدد الآراء حول المقومات الأساسية التي تقوم عليها الهوية الوطنية، إذ يراها البعض قائمة على عنصرين أساسيين هما التاريخ والثقافة، واضعا في اعتباره أن الثقافة هنا تشمل اللغة و الدين و التراث، بينما يرى آخرون بضرورة تفصيل تلك المقومات لتشكل رباعية اللغة و التاريخ و الدين و التراث الثعبي لأصحاب الهوية الواحدة، وأيا ما كانت تللك

الرؤى المختلفة فإنه ثمة اتفاق، على المقومات الأربع الأساسية سالف الإثارة إليها. و الحقيقة أن الخلاف والجدل لا يتعلق بتحديد تلك المقومات بقدر ما يتعلق بفهينا لها و المكانة التي يجب أن يشغلها كل منها، وعلاقات تلك المقومات مع بعضها البعض، و الدور الذي ينبغي أن تلعبه في حياتنا الحاضرة، وفي رسم مستقبلنا المنشود، فعلى سبيل المثال لا يوجد في الوطن العربي برمته من ينكر من أن لغنتا الأساسية هي اللغة

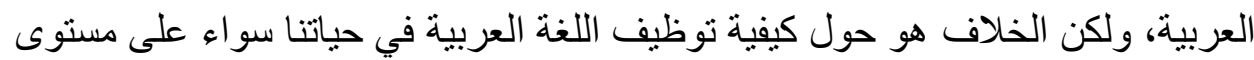
التعليم أو على مستوى العمل والإنتاج. ولذا فإنه يمكن تحديد المقومات الأساسية للهوية الوطنية في العناصر الأربع التالية و هي: اللغة، والمعتقدات، والتراث، والتاريخ المشترك، ويمكن تفصيل هذه العناصر على له له النحو التالي:(๕๕) وعي.

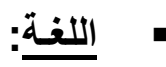

اللغة بمعناها العام تعني القدرة على التعبير، ولذا فهي عنوان الوجود الإنسـاني،

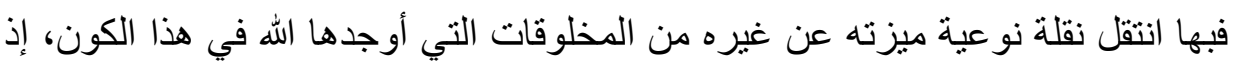

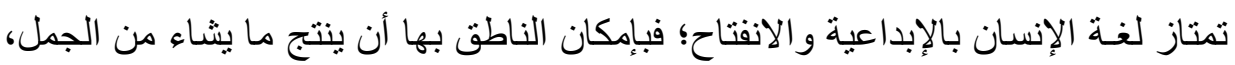
معبراً عن كل موقف يراه، وعن كل فكرة تخطر له دون عناء، كما أن اللغة وسيلة

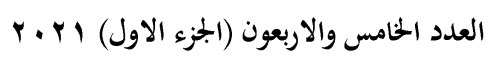


أثر برنامج إثرائي قائم على معايير العلوم اللجيل القادم (NGSS) في تنمية مهارات القرن الحادي والعشرين

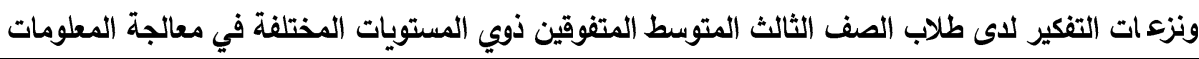

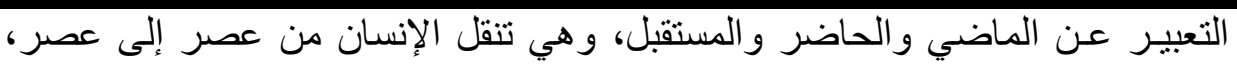
ومن جيل إلى جيل، ومن بيئة إلى بيئة، مستجيية بذلك لمتطلبات الحياة. (0؛ و الحديث عن طبيعة اللغة ومكوناتها يقود إلى فهم دقيق لهوية الأمة وكيفية تشكلها؛ ذلك أن اللغة عند النظر إليها كأداة للتواصل الإيجابي بين البشر، نجد أن هذا التواصل اللفظي يجعل الإنسان يخضع لعادات وتقاليد سـوكية وكلاميـة، تلزمسه بـأن يتصرف وفق منطق معين يرضي الجماعة التي ينتسب إليها، لذا فإن اللغة وحتى تبلغ حد كمالها المنطقي، يقتضي أن تجيء مقابلة تماما لأحوال المجتمع الذي توجد فيه، فتجيء أحرف الكلمات مقابلة لطبائع الأشياء، وتجيء المفردات مقابلة تماما لما في الطبيعة من هذه

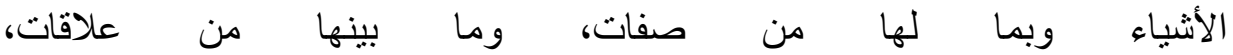

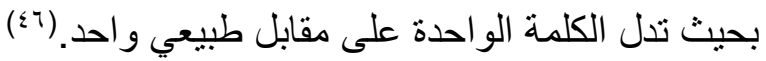
فإذا ما أضفنا إلى ما سبق، ما تمت الإشارة إليه من أن الهوية الثقافية ركن ركين

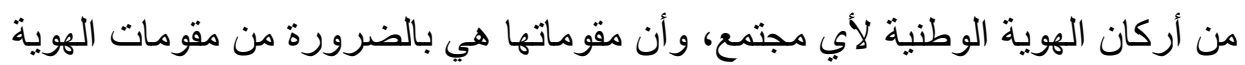

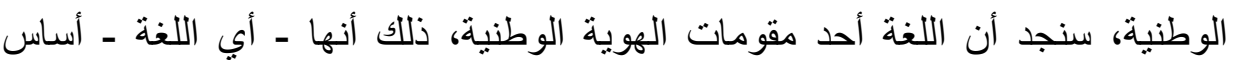
الهُوية الثقافية، فاللغة هي روح الأمة؛ لأنها الوعاء اللفظي والفكري الذي يُعبر عن مكوناتها الفكرية والوجدانية، والتي من خلالها يتواصل أفر اد المجتمع، فإذا ما عم هذا التواصل بين كل أفر ادها ولم يفتقر أحدهم إلى وجود لغة مشتركة تجمعه بهم، أدى ذلك إلى الحفاظ على المجتمع وبقائه.

ويؤكد أندرسون Anderson أن الهوية القومية أو الوطنية للأمم، عندما يُنظر إليها على أنها مجتمعات تخيلية، سنجد أن اللغة هي المكون الأساسي لبنائها، بل إن رابطة اللغة بين أبناء المجتمع الواحد تعتبر أكثر قوة من رابطة الدم.(v) لذلك فإنه في مجتمعاتتا تُعد اللغة العربية إحدى الركائز الأساسية التي تُحقق للأمة القوة والمنعة؛ باعتبار ها أداة لتوطيد الروابط، وتدعيم التفاهم والتقارب، كما أنها

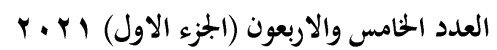

مجلة كلية التربية- جامعة عين شمس 
د. ولاء السيد عبد الله السيد صقر د. يحيى مصطقى كمال الدين

مستودع التراث الحضاري الزاخر بالقيم الروحية والمبادئ الأخلاقية بين الثعوب الأبين

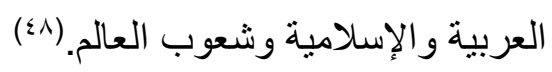

ومما سبق يتضح دور اللغة كمقوم من مقومات الهوية الوطنية في تعزيز ارتباط

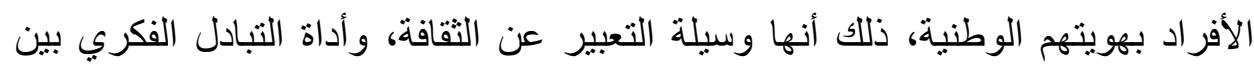
أفر اد المجتمع الواحد، و التي عن طريقها تنشأ رابطة التواصل الإنساني، ومن ثم يتحقق الانسجام بينهم، بل إن اتقان أفراد المجتمع للغتهم الأم ونو اصلهم عن طريقها يعمل على لى التغلب على مشكلة التو اصل بين الأجيال، والتي بدت جلية في عالمنا نتيجة لإهمال اللغة

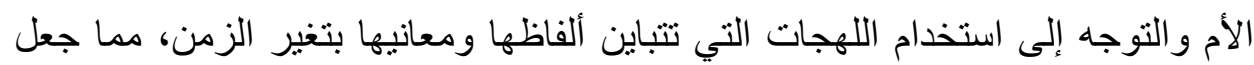
الثباب غير قادرين على التواصل مع ذويهم من ناحية، وغير قادرين على استيعاب العلوم التي تُقدم لهم باللغة العربية الفصحى من ناحية أخرى، وذللك لثيوع اللهجة العامية و غزو المصطلحات الأجنبية للغة التو اصل فيما بينهم.

\section{المعتقدات:}

تُعد المعتقدات مكونا أساسيا لهوية أي أمة، وربما كان في الغالب المكون

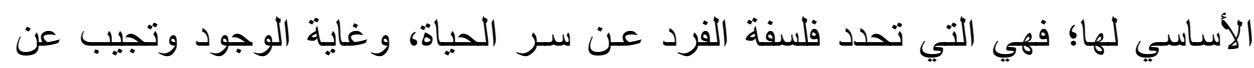
الأسئلة الخالدة التي فرضت نفسها عليها في كل الأزمنة من مثل: من أنا؟ ومن أين

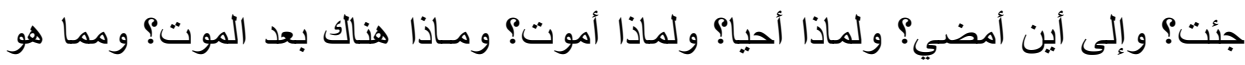

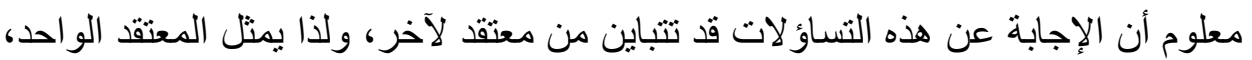

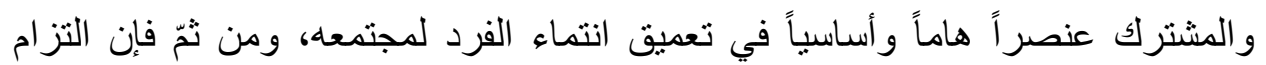
جماعة من الناس بمعتقد واحد يجعل توجهمه السلوكي و القيمي توجهاً مشتركاً. وغني عن البيان أن المجتمعات العربية هي مجتمعات إسلامية في غالبها، ولما كان جوهر الإسلام هو التوحيد، فقد ارتبط هذا التوحيد الديني بالتوحيد القومي، كوجهين لعملة واحدة، ليس على مستوى السياسة فحسب، و إنما على مستوى الحضارة، والدولة، 
أثر برنامج إثرائي قائم على معايير العلوم اللجيل القادم (NGSS) في تنمية مهارات القرن الحادي والعشرين

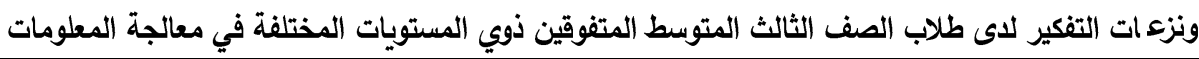
و الهوية، ولقد اشتد التأثير والتبادل بين الوجهين، فساعد التوحيد الديني على اتساق هوية

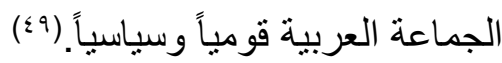
وفي هذا الصدد، وعلى اعتبار أن الدين الإسلامي أحد أهم المعتقدات الراسخة

G. في عقليات المجتمع الإسلامي، يثير عالم الاجتماع الفرنسي غوتساف لوبون Loboun المختلفة التي خلفها القرآن مرشدا لها تعمل أحكامه كما كانت تفعل منذ ثلاثة عشر قرنا، وقد تجد بين المسلمين عددا قليلا من الزنادقة والأخلياء ولكن لن نرى من يجرؤ منهر على انتهاك حرمة الإسلام في عدم الامتثال لتعاليمه الأساسية" (.0. إلا أنه في الوقت الذي يكون فيه المجتمع متعدد الانتماءات من فئات وجماعات عرقية أو دينية أو سياسية أو اجتماعية، فأنه يتوجب على القائمين على هذا المجتمع العمل على دمج هذه الانتماءات المتنوعة من أجل الوصول إلى هوية مشتركة تمثل مصالح المجتمع بانتماءاته الطبيعية المختلفة، "فالهوية المشتركة أو محاولة تحقيق الاندماج الفرعية بقدر ما نعني ضمان عدم تضارب بين الهوية المشتركة والهوية الفردية، وبناءً على ذلك تصبح السلطة هي القادرة على منح الهوية المشتركة، من خلال مؤسساتها المختلفة، وتصبح بذلك الهوية الفردية جز ءا من الهوية المشتركة.(0) ويتضح مما سبق أن الدين أو المعتقد المشترك بسهم بدرجة كبيرة في تكوين هوية وطنية متماسكة؛ إذ يمارس أبناء هذا المعتقد نفس الطقوس والعبادات، وتجمعه ذات القواعد السلوكية التي يهذبها الدين ويوجهها، ويرتضيها أبناء المجتمع ويلتزمون بها، وهنا نجد أنه لزاما على الجهات المؤثرة في المجتمع أن تعمل على تمثل السلوكيات القويمة للمعتقد الصحيح في تعاملها مع الآخرين، وليست الجامعات بمنأى عن هذا الأمر، فهي عندما تقيم العدل بين الطلاب، وتحقق المساواة في فرص التعليم، والجودة 
د. ولاء السيد عبد الله السيد صقر د. ئحيى مصطفى كمال الدين

في الخدمة المقدمة، إنما تحقق بذلك المبادئ الأساسية التي تقوم عليها الثرائع السماوية المختلفة، والمعتقدات الراسخة في عقول الأفراد، خاصة في الدول التي يكون بها تعدد مذهبي مثل مصر، و التي يقطنها المصريون من المسلمين و المسيحيين، و الذين هم على اختلاف شر ائعهم، إنما تجمعهم مبادئ و أسس دينية مشتركة، أضحت بالنسبة لهم سلوكاً عاماً ممارساً، حتى و إن كان البعض يشذ أحيانا عن ذلك السلوك، ومن ثمّ فإن تعزيز الجامعة لذلك السلوك في التعامل مع الطلاب وتدريسهم من شأنه أن يحقق ذلك المقوم الأساس في الهوية الوطنية.

\section{التتاريخ المشترك:}

تُعد دراسة التاريخ من أكثر الوسائل فعالية في بناء مستقبل الأمم؛ فمن خلال الوعي بتاريخ الأمة تكتمل الثقافة الوطنية وتبرز الثخصية الوطنية، ونتبلور الرؤية المستقبلية للمجتمع، ويحدث التكامل بين الماضي و الحاضر و المستقبل. لذا يُعد التاريخ ذاكرة للأمة؛ فتاريخ أي مجتمع يُعد بمثابة ذاكرته، وشعوره بذاته، و الأمة التي لا تعي تاريخها هي مثل شخص فاقد للشعور، أو الثخص التائه، أو من هو في حالة سبات أو غفلة، وأمثال هذه الأمم لا تستيقظ من سباتها ولا تعي ذاتها وعيا كاملاً، إلا بالفهم الصحيح لتاريخها.(or) كما أن دراسة التاريخ وفهمه على تنمية الثعور القومي عند الأفراد، وذللك بإبراز أهم المحطات التاريخية لنشأة الدولة أو الأمة، والتركيز على التضحيات الكبرى التي بُذلت لتحقيق الاستقلال المادي والفكري، وهو ما يرفع من مستوى الولاء والانتماء عند

النانشئة. (or)

ويؤكد ذلك ما يوليه الكيان الصهيوني من أهمية لتدريس التاريخ الوطني والديني، حيث يُقر رجال السياسة عندهم أن بقاء كيانهم واستمراريته متعلق بتشرب أبنائهم

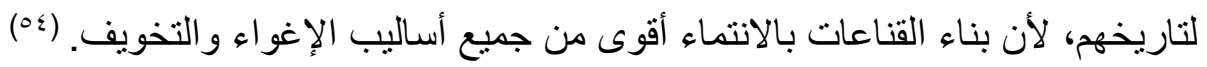


أثر برنامج إثرائي قائم على معايير العلوم اللجيل القادم (NGSS) في تنمية مهارات القرن الحادي والعشرين

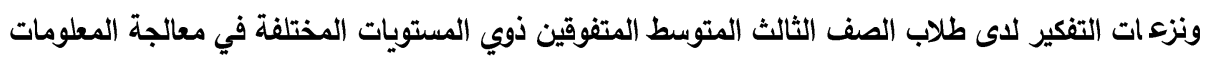

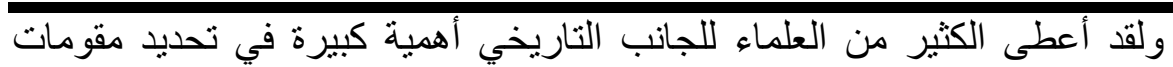
الهوية، حيث يُقدم بعضهم أهمية التاريخ على اللغة والثقافة المشتركة، في تحديده لعناصر الهوية. حيث تمت الإشارة إلى أنه إذا كانت اللغة مكون هام من أركان الهوية ولهية

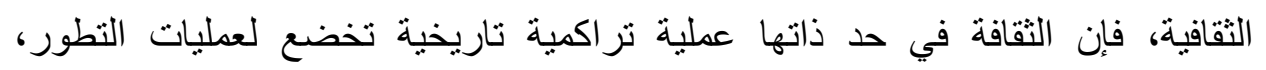
والتغيير، وليست هناك ثقافة لقوم أو مجنمع خالدة عبر العصور، وإنما هي في حركة

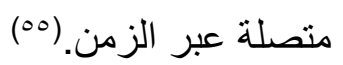

ومما سبق يمكن القول إنه يجب التأكيد عند تعزيز الهوية الوطنية لأبناء المجتمع الواحد على توعيتهم بتاريخ وطنهم ومجتمعهم، والتعريف بانتصاراته و انكسار اته،

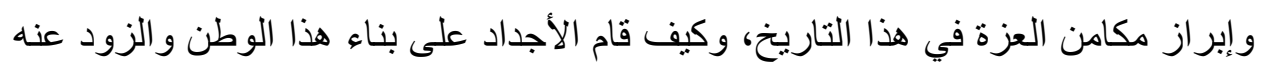

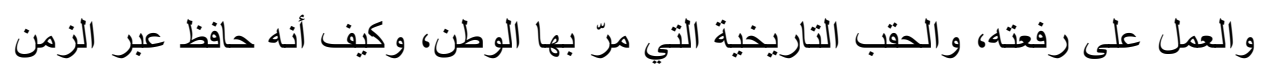
على قيمه و عاداته و أخلاقياته التي جعلته وطنا متماسكا عزيزاً قويا. -

يمثل التراث ذلك الثكل الحضاري الناتج عن تفاعل خصائص الأمة بكل مكوناتها مع بيئتها التي نشأت فيها، بكل ما تحتويه من تجارب وأحداث، أدت إلى طبعها بطابع

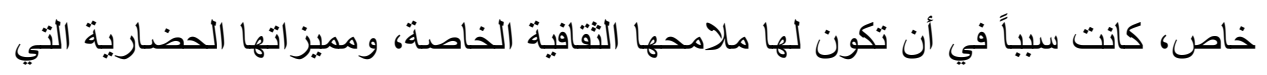

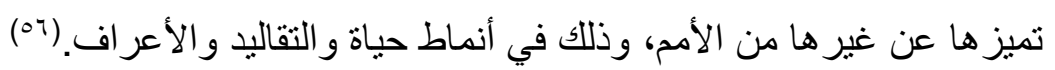

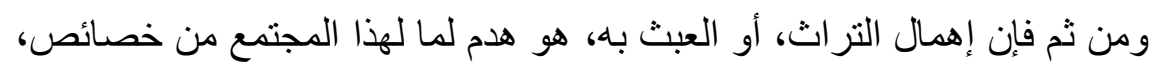
و عادات، وتقاليد وقيم، وأعراف، بل إن محاولة البعض الخروج عن التراث بحجة النها أنه

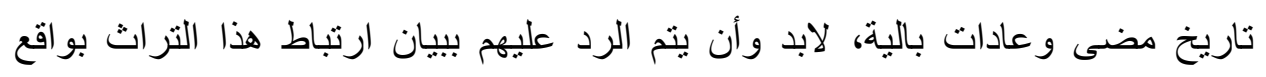

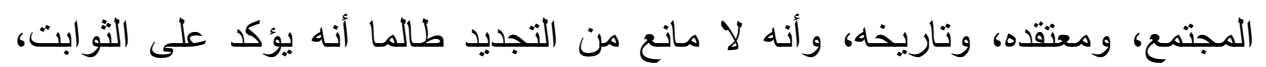
ويحافظ عليها. 
د. ولاء السيد عبد الله السيد صقر د. يحيى مصطفى كمال الدين

هذا وتكمن أهمية التراث في تعزيز الهوية الوطنية، في أن الموقف من التراث له له لهاءله أهمية خاصة في الثقافة؛ ذلك أن التراث يقع في صميم الهوية الثقافية ومن مقوماتها المهمة، إذ يُنظر للتراث على أنه نتاج المسيرة الحضارية للأمة كلها من علوم ومعارف و مؤسسات وفنون وقيم وفكر، وقد يُفهم على أنه الإنتاج الفكري للأمة أو بعضه كالأدب البه

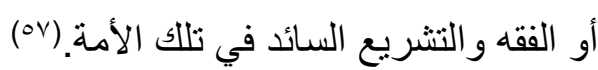
ولما كان التراث يقع في صميم الهوية الثقافية، فلابد من التمييز بين جانبي التأثير الثقافي للتراث الوطني، فهناك الجانب المعنوي القائم على التفكير والتأمل والثعور الاعتقاد، والجانب السلوكي المادي المتمثل في قواعد المعاملات والعلاقات بين الأفراد، وكذا الاختر اعات و الابداعات العلمية والفنية التي يحققها الأفر اد، وكلا الجانبين يتكاملان معا ليشكلا التراث الثقافي للأمة، وتتم ممارستهما على مستويين الأول مستوى عالمي خاص يتميز فيه أبناء الثقافة الواحدة عن غير هم، والثاني مستوى محلى وطني ينتقل من العام إلى الخاص أب من الثياب إلى نوع الثياب، ومن قواعد الأخلاق إلى نوعها ومحتواها القيمي، وهذا ما يجعل أنماط التقافة الوطنية التي هي إنى أسـاس الهويـة الوطنية تختلف بالضرورة عن الأنماط الثقافية العالمية في النوع وليس في الدرجة بجانبيها المادي و المعنوي. (O^) وبرؤية تحليلية للمقومات الأربع سالفة الذكر للهوية الوطنية اللغة والمعتقدات و التاريخ والتراث، سنجد أنها تشكل مع بعضها البعض كيانا واحدا متجانسا؛ إذ تشكل اللغة الهوية الثقافية للأمة، وترتبط الهوية الثقافية بالتراث الذي يقوى وتثنكل عبر التاريخ في ظل محددات سلوكية وقيمية يفرضها المجتمع من جانب من حيث ما يرتضيه من سلوك، والدين من جانب آخر من حيث ما يُقره من قواعد للتعامل بين البشر، بل إنه يمكن النظر في بعض المجتمعات إلى الدين على أنه الأساس التي قامت ثقافة هذا المجتم، كالمجتمع السعودي، و على الجانب نجد أن اللغة تلعب دورا بارزا في ثقافة النى 
أثر برنامج إثرائي قائم على معايير العلوم اللجيل القادم (NGSS) في تنمية مهارات القرن الحادي والعشرين

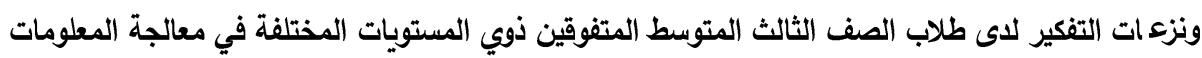

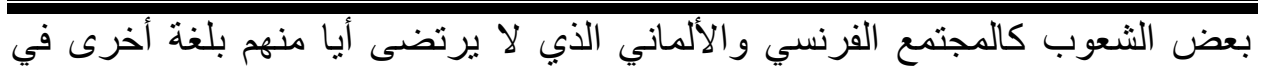
مجتمعه غير اللغة الأم له.

ونخلص مما سبق إلى أنه إذا ما أردنا أن نعزز هويتنا الوطنية، وأن نحافظ عليها، فلابد أن نغرس في أبنائنا الشعور بالفخر بلغتهم الوطنية، بل وأن نتحدث بها، و لا نرضى بها بديلاً في حواراتنا الخاصة والعامة، فاللغة هي الوعاء الذي يحوي ثقافة المجتمع ويتناقلها عبر الأجيال، كما يجب علينا أن نعلم أبناءنا تاريخ وطنهم، وما مر به

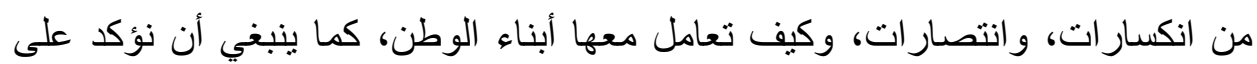
عاداتنا، وتقاليدنا، وقيمنا الوطنية، النابعة من معتقداتنا الوطنية الراسخة، وأن هذا كله لن لن يتحقق بمجرد القول و المحاضرات النظرية، و إنما من خلال التطبيق العملي، والقناعات الداخلية للقائمين عليها.

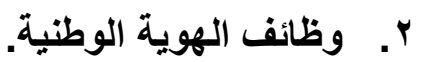

منذ ستة قرون، عقد ابن خلدون مقارنة نظرية لمجابهة العولمة استخلصها من تحاليل قديمة، وقد أفضت تللك المقارنة إلى أنـه كلمـا انفتحت الحدود و اتسعت الفضـاءات تصبح الحاجة إلى التمسك بالهوية أكبر، وبقدر ما يزداد الانفتاح على الآخر، تزداد النزعـة إلى الاحتماء بالهوية، وكأن هناك جدلية طبيعية تفرض قانونها على حياة الأوطان.(09) الترعه (1) إن الوظيفة التلقائية للهوية كما ير اها علم الاجتماع هي "حماية الذات الجماعية من

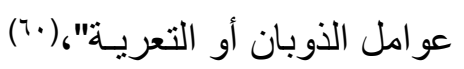
وهذا التصور الوظيفي لمفهوم الهوية، يتطلب منا أن نميز بين أمرين هما: هل الهوية شيء اكتمل وانتهى وتحقق في الماضي في فترة ومنية معينة، أو وفق نموذج المئ

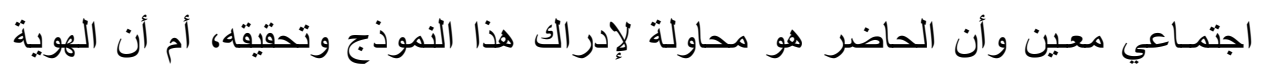




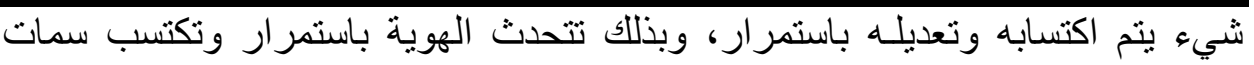

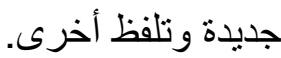

وأيا ما كانت النظرة لوظيفة الهوية، فإنها في جميع الحالات تلعب دورا هاماً في تحقيق تماسك المجتمع وتر ابطه، وتحافظ على عاداته وتقاليده وتراثه، وتعمل على أن

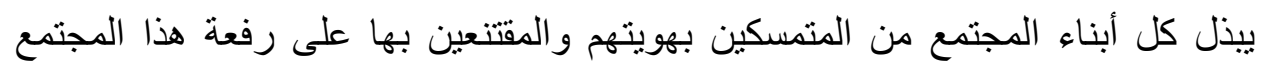
ورقيه.

إلا أن الجدل والصر اع الذي يدور دائما بين أنصار الأصالة والحداثة في تناولهم

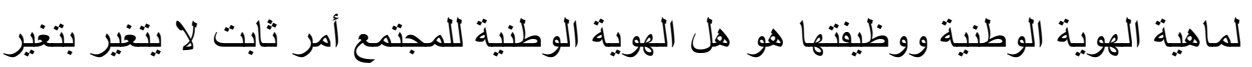
الزمن أم أنها تتجدد وتتطور بتطور المجتمع ونموه. لمهاه

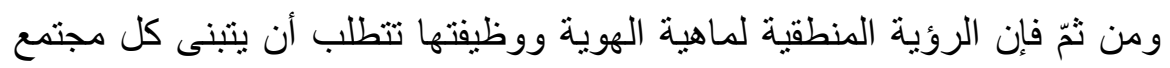
هوية ذاتية، يحافظ فيها على الثوابت التي لا تتغير كاللغة والمعتقد، ويجدد فيها ما هو قابل للتغيير كأنثكال الزي وأنماط الطعام.

إنّ للوعي بالهوية الوطنية والالتزام بها آثار عظيمة، تنعكس على الفرد و المجتمع

و الوطن بشكل عام، و لا سيّما متى قام الكل بواجباته خير قيام، فتمر ات ذلك تتمثل في: ـ قوة في النسيج الاجتماعي، الذي تعجز عن اختراقه مكائد الطامعين وأهو اء الفاسدين. - تحقيق نهضة علمية ومعرفية في شتى المجالات تنبثق من اعتزاز الأفراد بهويتهم الوطنية و العمل على تنميتها. - قوة في الاقتصاد الوطني، تتبع من الاستغلال الجيد للعقول المبدعة، والتطوير الدائم لبناء الوطن، للحاق بركب الحضارة، وريادة في مصاف الأمم. كما تعمل الهوية الوطنية على تحقيق مجموعة من الوظائف الهامة لأي مجتمع، و التي تتجلى في:(1) - ضمان استمر ارية الأمة؛ حيث تجمع الهوية أبناءها، بكل ما تحويه من مقومات.

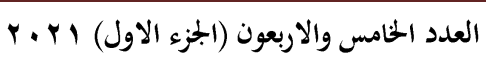


أثر برنامج إثرائي قائم على معايير العلوم للجيل القادم (NGSS) في تنمية مهارات القرن الحادي وإلعشرين

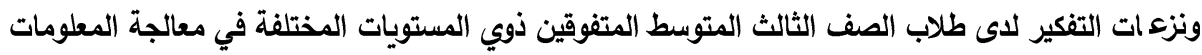

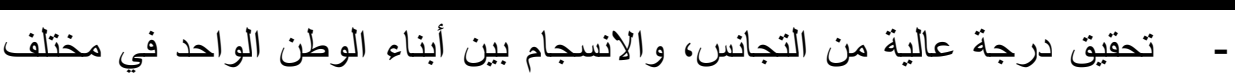
جهاته، بما يجمعهم على قو اسم مشتركة. - الحفاظ على كيان الأمة المميز لها، باعتبار أن الهوية الثخصية الوطنية للأمة هي التي تحافظ على صورتها أمام الأمم الأخرى.

و عليه فإن الحفاظ على الهوية الوطنية، هو حفاظ على الأمة ذاتها، وحفظ لكيانها وبقائها، فضياع الهوية الوطنية لأي مجتمع من المجتمعات معناه ذوبان هذا المجتمع في المجتمعات، و الثقافات الأخرى، ومن ثمّ ضياعه، وتبدله، بل و اختفائه. ثالثاً: الجامعة والهوية الوطنية: ثمة تأكيد على أهمية الدور الذي تلعبه الجامعة في تنمية الهوية الوطنية لطلابها، وتنمية انتمائهم لوطنهم الأم، من ثم يعرض هذا المحور علاقة الجامعة بتنمية الهوية الوطنية لاى طلابها وبناء على ما سبق، بدأت المؤسسات التعليمية و التربوية في ممارسة دور ها في تعزيز

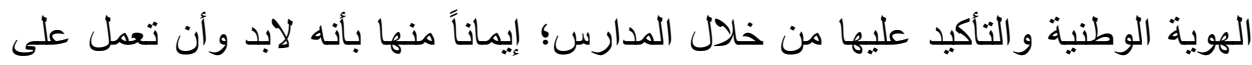
تشكيل هوية الأجيال منذ صغرها، إلا أنه وبمرور الزمن تبين لها أنه من الأنسب تعليم الطلبة المواطنة، وتنمية الهوية الوطنية لديهم في الفترة العمرية التي تلي السادسة عشر عاماً؛ باعتبار أنها السن الأقرب للمشاركة السياسة للثباب، وتعبر عن درجة من الوعي، والنضج، والفهم لمعنى أن تكون مواطنا في مجتمع، كما أنها الفترة العمرية الأحق النق بالتعليم والتأهيل لهذا الأمر، وبذللك اندرج تعليم سلوكيات المواطنة في مناهج، وأنشطة

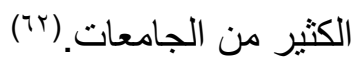
وقد أشارت معظم الإسهامات إلى أن تعليم المواطنة في الجامعات بشكل فعّال، يسهم في صياغة شخصية الطالب صياغة سليمة، إلا أن ذلك يتطلب نو افر برامج 
د. ولاء السيد عبد الله السيد صقر د. يحيى مصطفى كمال الدين

أكاديمية، واستر اتيجيات تدريسية غير تقليدية؛ يتم من خلالها التعلم عبر الانخر اط في ولاءئ داءله الجماعة وليس التلقين.

لذللك كان تعليم المواطنة وتعزيز الهوية الوطنية في الكثير من الجامعات يتم عن طريق الأنشطة الطلابية الجامعية، ومن خلال المشروعات العملية والمؤتمرات و اللقاءات التي يتبادل من خلالها الطلبة أطراف الحوار حول القضايا الوطنية والقيم المجتمعية التي تشغل الساحة الثبابية. ولقد كان هذا هو الأساس في ظهور توجه عالمي لتعليم المواطنة، يؤكد على أهمية العمل في إطار الجماعة، من خلال الاندماج في المنظمات التطوعية الوطنية، وهو ما أدى إلى أن تقوم العديد من جامعات العالم الآن بتنفيذ برامج لتنمية قيم المواطنة،

وتأكيد الهوية الوطنية من خلال توفير فرص، ومساحات للطلبة لخدمة مجتمعاتهم. (r) وترجع قوة الجامعة وعمق تأثثر ها في تنمية سلوكيات المواطنة والهوية الوطنية لطلابها لعدة أسباب منها: - - أنها تمتلك الموارد المادية اللازمة، والبشرية المؤهلة؛ لتحقيق أهداف الأنشطة الطلابية والتي تساعد في تنمية قيم المو اطنة لديهم. - - أن مشاركة الطلبة في جماعات الأنشطة، والرحلات، والجوالة التي تنشئها الجامعات وتعمل على الإشراف عليها، تنمي لديهم قيم المسؤولية، والمشاركة، والانتماء، والقيادة، كما تنمي لديهر مهارات العمل السياسي والاجتماعي ومهار ات تقبل الأخر وقيم الديمقر اطية وحرية الر أي.(؛ (ج) - أن طبيعة المرحلة العمرية لطلبة الجامعة، تجعلهم أكثر استعداداً لتحمل الواجبات، و أداء الخدمة الوطنية، كما تساعد عمليات التعلم الجامعي على اكتسابهم للكثير من القيم والاتجاهات الوطنية. وقد أكدت دراسة (عبد المجيد، 999 ()) على أن ممارسة الطالب الجامعي لحرية اختيار التخصص الأكاديمي، و الحوار و المناقتة 
أثر برنامج إثرائي قائم على معايير العلوم اللجيل القادم (NGSS) في تنمية مهارات القرن الحادي والعشرين

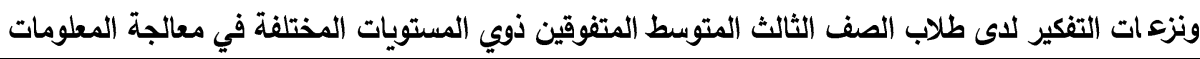
مع أساتذته، ومشاركته في الأنشطة، يحدث بدرجة كبيرة مقارنة بطلاب التعليم

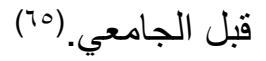
ويمكن التركيز في هذا الصدد على أن مسئولية الجامعة في هذا الثنأن تتلخص فيما يلي: 1. ت تنمية المسئولية المجتمعية.

تتضح طبيعة العلاقة بين ما تقوم به الجامعة ودور ها في تعزيز الهوية الوطنية، من خلال ما تضطلع به من مهام ووظائف، تعمل على تتمية هوية طلابها الوطنية، حيث تعد الجامعة مجتمعاً معلوماتياً يستطيع كل فرد فيه أن يستحدث المعلومة،

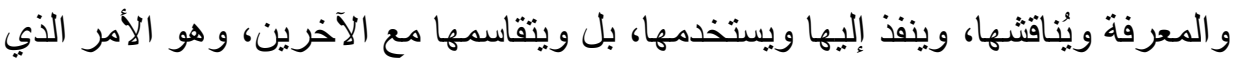
يسهم في تشكيل هوية الطلبة الوطنية، بالوقوف على خصائص الوطن ومكوناته من حيث: المعتقدات، و التاريخ، والتراث، و اللغة، بل وأيضاً من حيث العادات المتعارف عليها، والتقاليد المتبعة في تبادل المعرفة وتناولها، ويمكن النظر إلى المسؤولية الجامعية في تحقيق ذلك من خلال قيام الجامعة بمسؤولياتها المجتمعية على مستوى المؤسسة ذاتها أو عبر المنتسبين إليها، والتي تعد من الأمور التي لها تأثثر كبير في تعزيز قيم الانتماء و المواطنة؛ حيث يستشعر متلقي الخدمة بأنه يعيش في إطار مجتمع

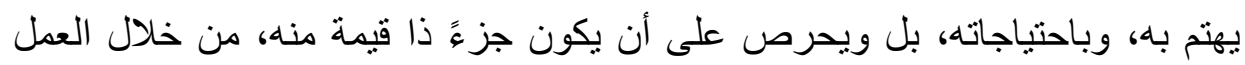
على تنميته، والنهوض به؛ ليكون عنصراً مشاركاً، وفاعلاً في مجتمعه، ولذللك تقوم الجامعة بمعرفة الاحتياجات العامة للمجتمع، وترجمتها إلى أنشطة عملية وتعليمية تقوم على تقديمها من خلال طلابها والمنتسبين إليها، وهي بذللك تؤكد على قيم المجتمع

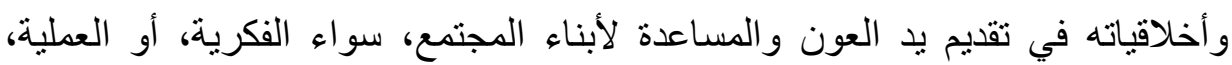
وتتمثل أبرز هذه الأنشطة في: (T) - الاستشار ات العلمية في مجالات الإنتاج و الخدمات، عن طريق الإفادة من خبرات

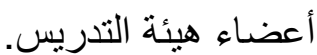

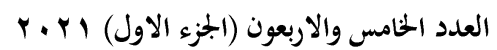

مجلة كلية التربية- جامعة عين شمس 
- - البرامج التنقفية والتوعوية، لرفع المستوى الثقافي لأبناء المجتمع وطلبة الجامعة أيضاً، وربطهم ببيئتهم ومجتمعهم. ــ ـ ـ الأعمال التطو عية التي تقدمها الجامعة للمجتمع، و التي يقوم عليها الطلبة و أعضاء هيئة التدريس. - - اللقاءات التربوية والعلمية التي تعقدها الجامعة للمجتمع لتكوين الثقافة العامة ومواجهة الأفكار الهدامة. الاحتفالات بالمناسبات الوطنية. - إبراز النجاحات على المستوى الثخصي و المؤسسي لأبناء الوطن بالإعلان عنها على الموقع الرسمي للجامعة. إن هناك العديد من العوامل التي تساعد على تعزيز وتتمية المسئولية الاجتماعية لدى طلبة الجامعة، من هذه العو امل:(YV) المناهج التعليمية: وتتضمن جميع الخبرات التربوية والأنشطة التي تقدمها المؤسسات التربوية، والتي تساعد الطالب علي الارتقاء العلمي باهتمامه بجماعته إلى مستوى تعقل الجماعة، وهو المستوى الذي لا يقف فيه الشخص إزاء جماعته موقف المنفعل بها أو المتوحد معيا فحسب، بل يقف منها موقف المتعقل لظروف حاضر ها، و المستو عب لتاريخها، و المتصور لآمالها وأهدافها. الجماعات التربوية (جماعات الأنشطة): يؤدي انضمام الطلاب للجماعات التربوية إلى تبنيهم لقيمها، واحترام كل عضو من أعضائها، والالتزام بنظامها،

$$
\text { و المشاركة في اختيار قائدها. }
$$

عضو هيئة التدريس (المعلم): وهو قائد ورائد اجتماعي في مؤسسته التعليمية، وبيئته، ومجتمعه، و هو يؤثر في طلبته، وينعكس ذلك في تحصيلهم، وسلوكياتهم واتجاهاتهم، ونظراً لأن اتجاهاته وميوله سوف تنتقل إليهم من خلال تفاعله

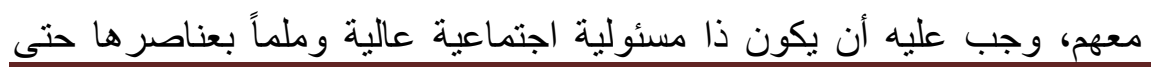

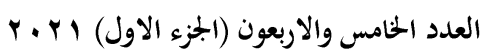

$$
\begin{aligned}
& \text { مجلة كلية التربية- جامعة عين شمس ونم }
\end{aligned}
$$


أثر برنامج إثرائي قائم على معايير العلوم اللجيل القادم (NGSS) في تنمية مهارات القرن الحادي والعشرين ونزء ات التفكير لاى طلاب الصف الثالث المتوسط المتفوقين ذوي المستويات المختلفة في معالجة المعلومات يقوم بدوره الإيجابي في تعزيز المسئولية الاجتماعية لاى طلابه بأقو اله و أفعاله لهئه ومظهره وسائر تصرفاته.

ومما سبق ينضح أن تنمية مفهوم المسؤولية الاجتماعية في نفوس الطلاب الجامعين، يمثل أحد جو انب تعزيز الهوية الوطنية لاى طلاب الجامعة، وأن تحقيق تلك التنمية يتوقف على ما يقوم به أعضاء هيئة التدريس من جهود وممارسات وما يحمله من ميول واتجاهات إيجابية نحو مجتمعه الأمر الذي ينعكس على طريقة تدريسه ويظهر أثره في قناعات الطلاب وممارساتهم، وان هذا الأمر لا يقتصر على ما يقوم به عضو هيئة التدريس فقط، و إنما يمتد ليشمل الأنشطة الطلابية الجامعية التي تغرس في نفوس الطلاب الانتظام و المشاركة المجتمعية، وأن الجامعة يمكنها أن تقوم بالعديد من الأنشطة و الممارسات التي تتمكن من خلالها من تحقيق تنمية المسؤولية الاجتماعية في نفوس الطلاب من خلال ما تعقده من ندوات ولقاءات ثقافية وتربوية، وما تقدمه من خدمات مجتمعية، وما تنظمه من احتفالات ومناسبات وطنية. r. غرس الانتماء للوطن. يثكل الانتماء جذر الهوية، وعصب الكينونة الاجتماعية، وهو الإجابة عن سؤال من نحن؟ كما أنه هو صورة الوضعية التي يأخذها الإنسان تجاه الجماعة، إذ يشكل الانتماء مجموعة الروابط التي تشد الفرد إلى الجماعة، ويرى المنظرون أنه ينبغي أن يُعبر كل برنامج در اسي على مستوى الجامعة عن قيم الانتماء والمواطنة، ذلك أن التعليم الجامعي هو اللبنة الأولى في تحقيق الديموقراطية والتقدم في عدد ليس بقليل من دول

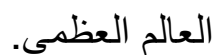
ومن ثمّ فان نظرة البعض للتعليم الجامعي على أنه تعليم للصفوة، يخل بقواعد النظام الديموقراطي، ولذلك فإن من أول خطوات صناعة الديموقر اطية في نظم التعليم الجامعي من أجل ترسيخ قيم الانتماء والمواطنة أن يكون للجميع، وأن برتبط بالمجتمع، 
د. ولاء السيد عبد الله السيد صقر د. يحيى مصطفى كمال الدين بحيث يعمل على مساعدة المجتمع في تخطي مشكلاته، يُضاف إلى ذلى ذلك أن صحة المجتمع المحلي تتوقف على مستوى النشاط الديموقر اطي في الجامعات لترسيخ قيم

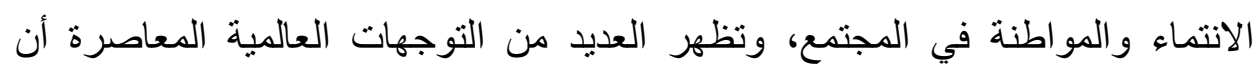

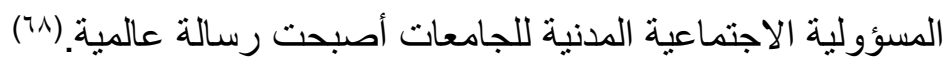
وتجدر الإشارة إلى أن هناك جوانب كثثرة تؤثر في تعزيز قيم الانتماء والمواطنة

لاى طلبة الجامعة من أهمها: (79) - أن إيمان أعضاء هيئة التدريس بأهمية وقيمة الوحدة الوطنية يساعدهم على حسن ترسيخها وتعزيزها عند الطالب. - أن تطبيق أليات تعزيز الوحدة الوطنية في العمل الأكاديمي بالجامعة يحقق منافع

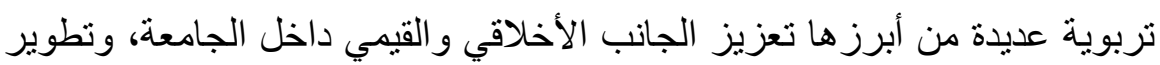
أليات العمل مع الطلاب لتحسين أدائهم الأكاديمي، ومساعدة الطلاب على تنمية إدراكهم الوجداني الإيجابي نحو بلادهم، وتحفيز هم على الثعور العملي بالمسؤولية الوطنية للتعلم الجاد، وضبط سلوكياتهم، والسعي لحياة كريمة شريفة في مجتمعهم. وقد أشتارت العديد من الكتابات إلى أن هناك آليات عديدة يمكن أن تتبعها الجامعة

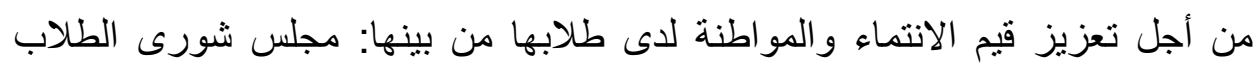
و التربية المدنية الجامعية، وتفعيل كل من وسائل التواصل الاجتماعي وأنشطة العمل التطوعي، وممارسة أنشطة التعود على طاعة النظام والقانون ومناتنط مراقبة الأداء وتشجيع النزاهة ومحاربة الفساد، واكساب الطلاب مهارات حلّ المشكلات، وتكليف الطلاب بأنشطة بحثية في مجال الانتماء والمواطنة، هذا بالإضافة للمقررات الثقافية

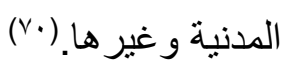
مما سبق يمكن القول إن الجامعة يمكن أن تعلب دوراً مهماً في تتمية الانتماء في نفوس الطلبة، من خلال ما تقوم به من ممارسات على مستوى المؤسسات و أعضاء هيئة 
أثر برنامج إثرائي قائم على معايير العلوم اللجيل القادم (NGSS) في تنمية مهارات القرن الحادي والعشرين

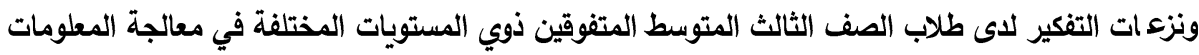

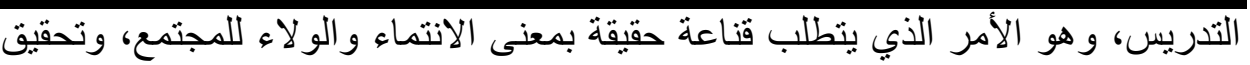
ذلك عملياً من عدد من الآليات والأنشطة بدءً من الاحتفالات بالأيام الوطنية والمناسبات

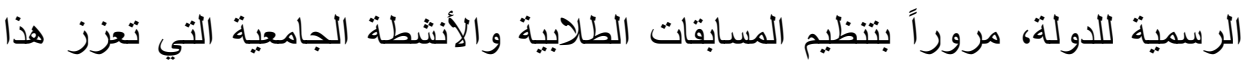
الانتماء، مرورا بالأنشطة التطوعية وتطبيق النظام واكتساب مهارات حلّ المشكلات، حيث يتعرف الطالب في كل مناسبة وممارسة على معلومة جديدة عن وطنه، ويترسخ في نفسه معنى أجمل عن هذا الوطن وما قام به أبناؤه من أجل الحفاظ عليه، و الذود عنه. رابعاً: وسائط الجامعة في تنمية الهوية الوطنية: إن تعزيز الهوية الوطنية وتنمية قيمة المواطنة الصالحة لدى الثباب يمكن أن تقوم به الجامعات من خلال وسائط عدة تتمثل في المقررات الدراسية، وواجبات ومسؤوليات أعضاء هيئة التدريس و الأنشطة الجامعية.

فالجامعة من خلال ما تدرسه من مقررات دراسية عبر بر امجها المختلفة تستطيع

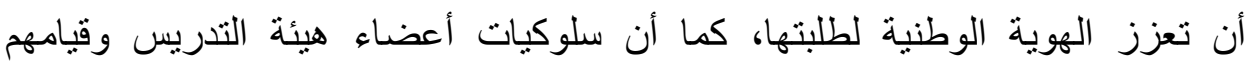
بو اجباتهم ومسؤولياتهم التربوية، ومشاركة الطلاب في الأنشطة الجامعية من شأنه أن هُه تعمل على تحقيق ذات الهذف. وحتى تتضح التأثيرات التي بمكن أن تحققها تللك الوسائط، نعرض لها بشيء من التفصيل، وذللك على النحو التالي:

\section{1. تعزيز تعلم اللغة القومية والتعليم بها:}

تعد اللغة القومية كما سبقت الإشارة مكوناً هاماً من مكونات الهوية الوطنية للشعوب، وهي المعبر عن شخصيتهم القومية، كما أن استخدام اللغة القومية في التعليم و التعلم من شأنه تحقيق عدد من الفو ائد والمزايا التي تعود بالنفع على الثعوب، من تلك

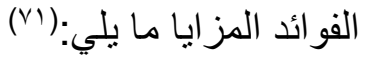


د. ولاء السيد عبد الله السيد صقر د. يحيى مصطفى كمال الدين

تيسير الحصول على فرص التعلم، ذلك أن تقديم المعلومات والمعارف باستخدام اللغة الأم التي استخدمها الأطفال وتمكنوا منها، يُسهل عليهم الحصول على بلى لئ

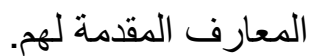
تسهيل عمليات نقل المعرفة العلمية والتكنولوجية لمتعلميها بين أبناء الثعب

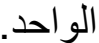
تشجيع المتعلمين على در اسة لغات أجنبية أخرى من شأنها المساهمة في تعرف المتعلمين على مزيد من المعارف العلمية والتكنولوجية، استنادا إلى قوة الأساس اللغوي للغة الأم. التعبير عن الثقافة المجتمع و عاداته باستخدام اللغة القومية، لتصبح اللغة بمثابة سفير التواصل الثقافي، مما يتيح الفرصة للتواصل، الاعتماد المتبادل، والثراء الإنساني. تحقيق التواصل الإنساني بين المجتمع الواحد وتجنب الاغتراب الذي يقود

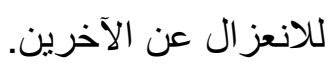
دعم التعامل الفريقي، والاعتماد المتبادل بين أبناء الثعب الواحد، ممن يستخدمون ذات اللغة. ومما سبق، يتبين أهمية تعلم اللغة القومية والتعليم بها؛ في تيسير الحصول على هي المعرفة، والتعلم، وتحقيق التواصل الاجتماعي، والاندماج بين سكان المجتمع الواحد، كما أنها وسيلة فاعلة في التعبير عن مكونات الثقافة الأم، الأمر الذي ييسر التفاهم، ولهُ والانسجام، والتناغم بين الثعوب، بل ويقلل فرص الاختلاف، و الكراهية، وسوء الفهم، الأمر الذي يدفع الشباب للافاع عن ثقافتهم، والتمسك بها، وتقدير ها، و الاستعداد لتقدير ثقافات الآخرين في نفس الوقت. و لإدر الك أهمية اتقان اللغة القومية والتمكن منها، أكدت المنظمات الدولية، ومو اثيق حقوق الانسان، على حق الفرد في الحصول على فرص التعلم المتاحة له باستخدام لغته 
أثر برنامج إثرائي قائم على معايير العلوم اللجيل القادم (NGSS) في تنمية مهارات القرن الحادي والعشرين

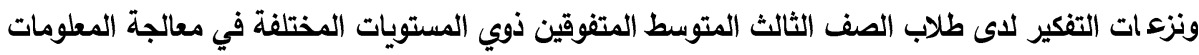
القومية، حتى وإن كان من الأقليات، أو من المهاجرين إلى بلاد أجنبية، وذلك تحقيط لهيقاً لمبدأ تكافؤ الفرص التعليمية، والعدالة والمساو اة عند إتاحة فرص التعلم، بل و لإعطاء الفرصة لأبناء ثقافة معينة للتمكن من لغتهم القومية، والانتماء لمجتمعهم الأم، حتى و إن كانوا بعيدين عنه، نظرا لظرف الإقامة والعمل في بلاد أجنبية، كما أنه نتيح تحقيق التنوع و الثراء الإنساني بالمجتمع الأجنبي، نظراً لوجود لغات متباينة، يسمح وجودها بالتفاعل، و التعاون، و الاندماج، والاعتماد المنبادل، وتحقيق المزيد من التعارف بين الثقافات المتباينة، مما يعمل على تجنب الصر اعات بين المتباينين ثقافياً ولغوياً، حيث يشعر كل منهما، خاصةً الأقليات منهم، بتقدير السلطات التربوية لهم، وحرصهم على الى اعطائهم كافة حقوقهم التربوية، باستخدام لغتهم الأم، التي بالتأكيد تعمل على دعم انتمائهم لثقافتهم القومية.(Yr) ولعل استخدام اللغة القومية في التدريس بالجامعة، من شأنه تحسين عملية التعلم للطلاب الجامعيين، حيث يحصلون على المعارف باستخدام اللغة الأم، كما أنهح يشعرون بأهمية لغتهم القومية، ومن ثم يقويّ ارتباطهم واعتزازهم بها، لكونها وسيلة التعلم، والحصول على المعرفة الجديدة المقدمة لهم في إطار دراستهم الجامعية، الأمر الذي يساعدهم على تتمية قدراتهم، ليست اللغوية فحسب، و إنما المعرفية، والاجتماعية،

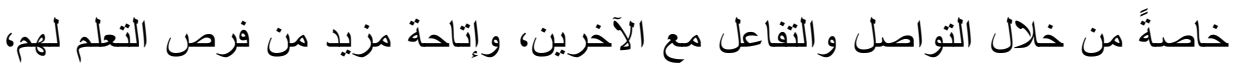

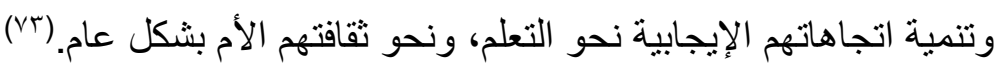

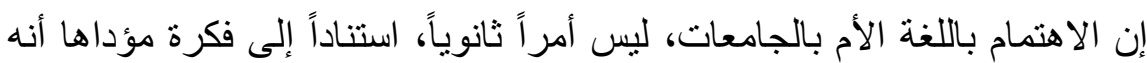
بالفعل قد تم تدعيم الثقافة القومية والتمكن من اللغة الأم بالمراحل الدراسية السابقة للار اسة الجامعية، وعلى العكس، تعد المرحلة العمرية للطلاب الجامعيين أكثر خطورة من المر احل العمرية السابقة لها، ومن ثم يعتبر الاستمرار في دعم تمكن الثباب من اللغة الأم، هو الفرصة الحقيقية لاستقطاب الثباب نحو التمسك بهويتهم الوطنية، في

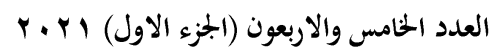

$(352)$
مجلة كلية التربية- جامعة عين شمس 


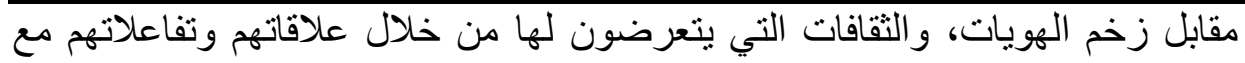
الآخرين، التي تتسع وتضم العديد من الأجناس و الهويات بشكل عام، نظراً لشغفهم في

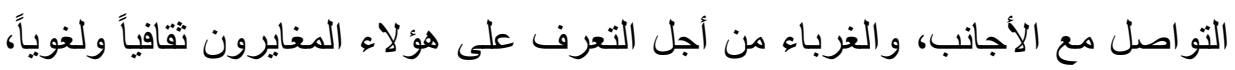

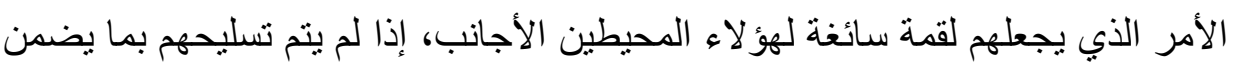
بقائهم وتمسكهم بوطنهم الأم. r. - ب. المقررات الدراسية الجامعية. تمثل المقررات الإطار العام للتعليم الذي بموجبه يتم تأهيل الدارسين، و إكسابهم القيم والأنماط السلوكية المرغوبة، وتزويدهم بالمعارف، و المهارات اللازمة لحياتهم، كمو اطنين يمتلكون تلك الثخصية الفاعلة في مجتمعاتهم؛ فالمناهج هي الداعم الأساسي لإعداد الأجيال القادمة، وتأهيلها لتكون قادرة على العمل المنتج البناء، من أجل إحداث النقلة المطلوبة للمجتمع من التخلف إلى الرفاه الاقتصادي، ومن التعصب الحزبي إلى الديمقراطية وقبول الآخر، ومن النظر إلى المصلحة الخاصة إلى مراعاة المصالح الوطنية العامة. ويتأكد ما سبق عند ملاحظة أن المقرر ما هو إلا حلقة وصل بين فلسفة التربية و أُطرها النظرية والفكرية القائمة على أسس قيمية، ومجتمعية، وتقافية، ونفسية، وبين التعليم باعتباره الجانب التطبيقي لكل ما سبق، فمن خلال التعليم تتحقق الأهداف التربوية و التي من أهمها: توجيه الناثئة نحو السلوك المرغوب به، لتحقيق تكيف الفرد مع ذاته ومحيطه، الذي يشاركه ذات الأطر ، و الأهداف، والممارسات، و القيه.

لذا فإنه من أجل تعزيز الهوية الوطنية للطلاب يكون من المفيد أن تشتمل المقررات الدراسية التي تشتملها المناهج و البر امج الأكاديمية المختلفة على مجموعة من النصوص المباشرة أو الضمنية التي توضح للطلبة أهمية تَمَتُل واكتساب قيم الانتماء و المو اطنة كما تظهر ها النصوص الثرعية من جهة، وكما تتطلبها قو اعد النشأة و التكوين في العلوم النظرية من جهة أخرى، مع مر اعاة ألا يكون التركيز منصبًا على المعلومات

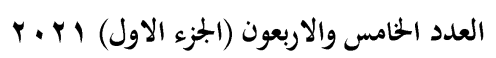


أثر برنامج إثرائي قائم على معايير العلوم اللجيل القادم (NGSS) في تنمية مهارات القرن الحادي والعشرين

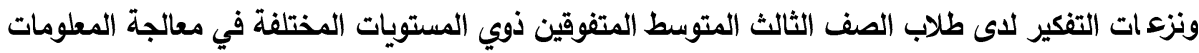

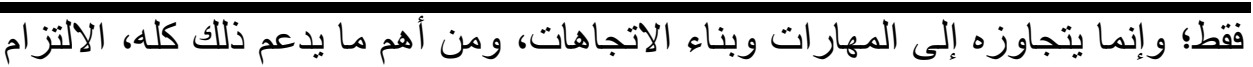
بالمكونات الثقافية الوطنية في القول والعمل، وأن تُوضع لذلك المعايير المناسبة

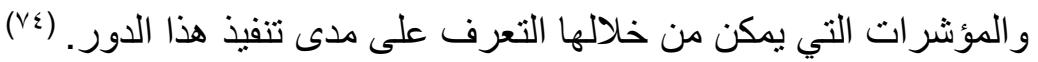
وفي دراسة للتعرّف على أثر المناهج في إكساب القيم الوطنية في نظام التعليم الإيطالي، تمت الإشارة إلى أن التربية الوطنية هدف أساس من أهداف نظام التعليم العالي الإيطالي، ولذا فهي تؤكد على مفاهيم، ومنطلقات سياسية وطنية تحث على المحافظة على الدستور واحترام حقوق الوطن، والتعريف بحقوف المواطنين، وتنمية المشاركة السياسية لديهم، وتوضح الدراسة أن مناهج التربية الوطنية حظيت بعدة مراجعات وإصلاحات؛ بهدف إدخال مفاهيم وقيم جديدة، مثل: التعليم من أجل السلام، و التعايش مع الآخرين، واحتر ام الأقليات والهوية الوطنية....الخ، كما أوضحت الدراسة أن المناهج الجامعية تسهم في تعزيز هذه القيم، والمفاهيم، وتثجيعها.(V0) وفي إسبانيا يشير نافال وآخرون Naval et al، إلى أن نظام التعليم العالي الإسباني أدرك أهمية التركيز على إصلاح مناهجه؛ لتلبي احتياجات الهوية الوطنية، خاصة بعد تنامي دعاوى العولمة، وبعد قيام الاتحاد الأوروبي الذي أصبح يمد ظلاله على الدول الأوروبية كافة، بعيداً عن حواجز اللغة والثقافة، لذلك تمت المناداة بتعزيز الهوية الوطنية وتفعيل دور الجامعات في إعداد المواطن الجديد في القرن الحادي و العشرين، وذلك من خلال مر اجعة البر امج التعليمية، و إجر اء البحوث العلمية، وصياغة السياسات التربوية وإصلاح المناهج الجامعية على أسس حديثة. (vi) وفي الصين حرصت الدولة على أن يتشرب النشء للغته الأصلية وثقافته الصينية، ولذلك فقد أعلنت الدلولة منذ العام ا ... م، ممثلة في وزارة التعليم بالصين على أنها لن تسمح بتعليم اللغة الإنجليزية في مدارسها لطلابها قبل الصف الثالث الابتدائي، واعتبار مقرر اللغة الإنجليزية من المقررات المطلوب اجتياز ها فقط. (Vv) 


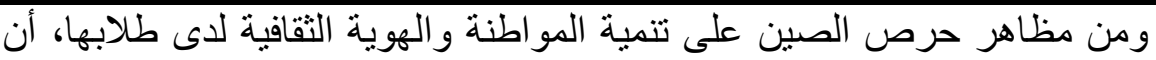
جعلت مادة التربية الوطنية مادة إجبارية في التعليم وضّمنو ها أنشطة عملية وحرصوا من خلالها على تتمية مهار ات المشاركة وقيم المسؤولية لدى الطلاب، و التأكيد من خلال تدريبهم على هذه المهارات على التماسك الاجتماعي بين أفراد المجتمع. (V^) وفي المملكة العربية السعودية تقدم جامعة الإمام محمد بن سعود الإسلامية مقرر تحت مسمى "قيم الإسلام وخصائصد"، وهو أحد المقررات التي يُقدمها قسم الثقافة الإسلامية للتاككيد على الثقافة الإسلامية للمجتمع السعودي، كما تدرس جامعة طيبة مقرر "القيم والخلاق الإسلامية" كأحد المتطلبات الجامعية التي يدرسها جميع طلاب الجامعة، و هي مقررات تعمل على تعزيز الثقافة الإسلامية للمجتمع السعودي، بما يدعم الحفاظ على هويته الوطنية الإسلامية القائمة على اللغة العربية وتعاليم الدين الإسلامي والتقافة الإسلامية التي تشكل عادات المجتمع السعودي. ومما سبق يتضح كيف أن للمقررات الدراسية أهمية كبيرة في تعزيز الهوية الوطنية للثباب الجامعي، و هو ما يتطلب فهما صحيحا لمعنى محتوى المقرر الدراسي، وألا يقتصر الأمر على المعارف والمعلومات، و إنما يمتد ليشمل أيضا طر ائق التدريس، وأساليب التقييم المستخدمة، والوسائل التعليمية، وكيف يتم توظيفها من أجل تحقيق الأهداف التربوية والتي من بينها تعزيز الهوية الوطنية للطلاب، وكل ما سبق يقوم عليه عضو هيئة تدريس واع بعمله، مدركا لحقيقة رسالته، مستشعرا لدوره في النهوض بالأمة من خلال إعداد جيل، ليس فقط يمنلك المعرفة والمهارة، وإنما أيضا يحمل القيم و العادات و الاتجاهات الإيجابية و الو لاء و الانتماء لوطنه ومجتمعه.

فمن بين أدوار الأستاذ الجامعي تعزيز الهوية الوطنية عند الطلاب، وذلك عبر:(v9) إكساب الطلاب القيم و المبادئ الأخلاقية الحميد والاتجاهات التربوية الإيجابية.

$$
\text { مساعدة الطلاب على النضج الاجتماعي. }
$$

مساعدة الطاب على التعبير عن آر ائهم و أفكار هم بكل صر احة وموضو عية.

العدد الخامس والاربعون (الجزء الاول) ا Y. r.

(355)
مجلة كلية التربية- جامعة عين شمس 
أثر برنامج إثرائي قائم على معايير العلوم اللجيل القادم (NGSS) في تنمية مهارات القرن الحادي والعشرين

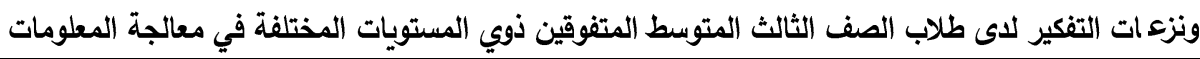

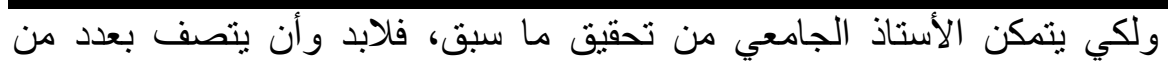
الصفات التي تؤ هله لتحقيق ذلك، وتتجلى هذه الصفات في:(•) الوسطية في الفكر والتوازن في الأداء: إذ يجب أن يكون الأستاذ الجامعي منوازنا معتدلا في سلوكه وتصرفاته مع طلابه، وهو ما يظهر في وسطية التصور التفكير و الثعور، ووسطية التنظيم والتنسيق والارتباط و العلاقات، ولا شك أن وسطية

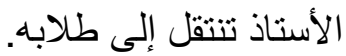
الحرص على غرس الأخلاق الحميدة في طلابه: بالعمل على إنزال المعنى الاخلافي في قلوبهم بما يعمل على تطهير سرائرهم، فيتجلى ذلك في اعتدال فكر هم وحسن سلوكهم في تعاملهم مع الاخر، وفي ارتباطهم بأمتهم ومجتمعهم. الاهتمام بالحوار؛ ذلك أن أسلوب الحوار أنجح وأجدى في الوصول إلى الحقائق وصحتها، شريطة أن يكون هذا الحوار قائما على إنصات الأستاذ للطلاب مهما كان خطأ كلامهم وشططهم و غلو هم، بحيث يكسب ثقتهم ويشعر هم بأن لهم كل الحق في الدفاع عن آرائهم، وأن يعتمد سيل الاقناع العقلي في التحاور معهم، وأن ير اعي البشاشة و المرح أثناء حواره معهم. استيعاب الأستاذ الجامعي لتخصصه وطلابه، فاستيعابه لتخصصه فيكون بإلمامه به و أبعاده وطر ائقه و أبعاده و غير ها من الأمور، أما استيعابه لطلابه فيكون بأن

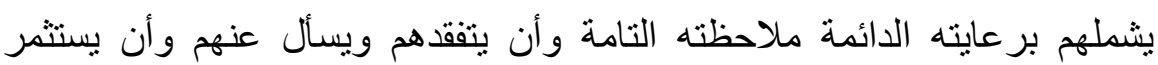
طاقاتهم ويوجه أفكار هم ليتولد على أثر ذلك الوفاء للأساتذة والتقدير لهمن وهي قيمة مجتمعية عالية. ومما سبق يتضح أنه لا جدوى لمقررات وبرامج در اسية ومناشط جامعية تعمل على تتمية الهوية الوطنية للطلبة الجامعيين، مالم يكن الأستاذ الجامعي القائم عليها متمتعًا بالخصائص وممنلكاً للمهار ات التي تمكنه من تحقيق ذلك. 
إن مشاركة الطلبة في الأنشطة الطلابية على مستوى الجامعة، يشكل منعطفًا مهمًا في استكثاف مفهوم هويتهم الوطنية، وترسيخه بصورة أكثر عمقًا وشمولية، حيث تشير الدراسات إلى أن الحركات الطلابية بأنشطتها المختلفة تسهم في تنمية الطلبة سياسيًا،

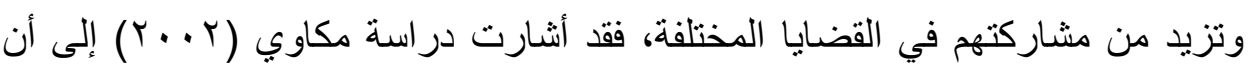
الحركات الطلابية في الجامعات الفلسطينية كان لها الأثر البالغ في انخر اط الطلاب في

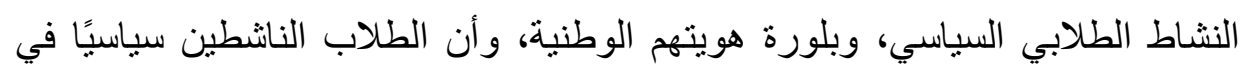

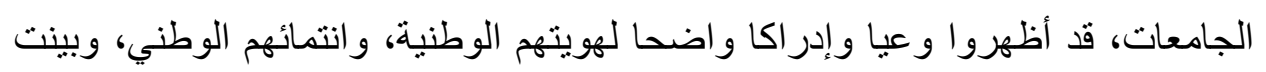
الدر اسة أن مفهوم الهوية يتعزز، ويتأكد من خلال تجربة النشاط الطلابي نفسها. وفي هذا الصدد تؤدي الأنشطة الطلابية، كالانتخابات، والمهرجانات، و والندوات اتهنات

الثقافية، و اللقاءات السياسية دورًا كبيراً في تنمية الثخصية الاجتماعية للطلبة.

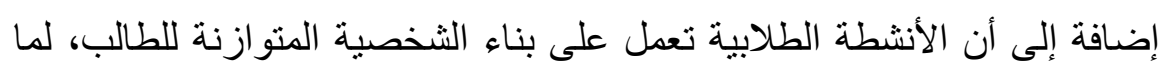
تتضمنه من عناصر تسهم في تتمية الجوانب الروحية والاجتماعية والعقلية والجسمية

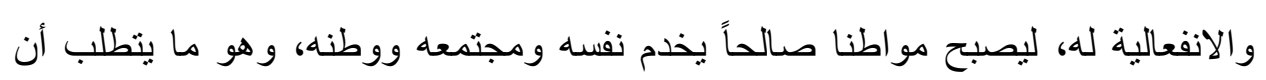
تتنوع تللك الأنشطة لتشمل الجوانب البدنية و الثقافية والعقلية و القيمية والروحية. وللأنشطة الطلابية الجامعية عدد من الأهداف منها: (1) - المساهمة في تنمية الخلق السليم والسلوك القويم للطلبة. - - ترسيخ القيم الاجتماعية كالتعاون و المنافسة الثريفة. - ت تتمية مهار ات تخطيط إنجاز الأعمال، وتحمل المسؤولية. - تدريب الطلبة على التعبير عن آرائهم بموضوعية، واحترام آراء الأخرين، وتطبيق مبدأ الثورى بينهم. 
أثر برنامج إثرائي قائم على معايير العلوم اللجيل القادم (NGSS) في تنمية مهارات القرن الحادي والعشرين

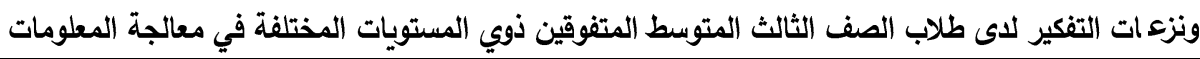

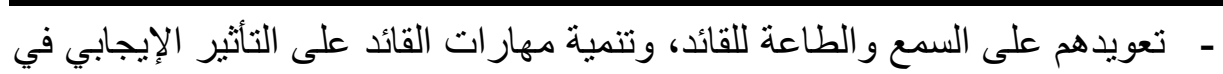
زملائه من خلال كونه قدوة حسنة سلوكا وفكر ا وممارسة. كما أن الأنشطة تسهم في تأكيد هوية الطلاب الوطنية من خلال المشاركة البناءة للطالب في العمل الجماعي، وحب النظام، والحفاظ على الملكية العامة، والعمل بروح الفريق وحرية الرأي. ويضاف إلى ذلك أن الأنشطة تعمل على تحقيق التقبل،

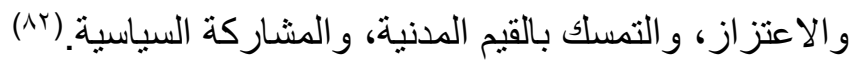
هذا وتنفذ الجامعات العديد من الأنشطة الطلابية، التقافية منها كالندوات و اللقاءات و إصدار الصحف و المجلات والنشرات والمهرجانات الخطابية، و إلقاء القصائد الشعرية، و الفنية منها كالرسوم التعبيرية و الزخرفية والأشغال اليدوية و النسيج و التمثيل و المسرح، إضافة إلى النشطة الرياضية كالمباريات والعروض الرياضية والاحتفالات والمهرجانات، والنشاط الصحي كالإسعافات الأولية وحملات الوقاية من الأمراض وتنظيم الزيارات الميدانية للمستشفيات والمؤسسات الصحية، والنشاط الاجتماعي كالرحلات و الزيار ات الميدانية والأعمال التطو عية.(^) و هذه النشاطات على اختلاف مجالاتها وتتوعها إذا ما أُحسن إدارتها وتنفيذها، كان لها المردود الإيجابي على الطلبة من جانب وعلى المجتمع من جانب آخر، الأمر الذي يُحدث التماسك الاجتماعي والتقارب الإنساني بين الأجيال المتعاقبة، مما يقود إلى أن تثوارث الأجيال القيم والمعتقدات والثقافات وتتقبلها بدلا من الصراع الذي نشهده كثيرا بين الثباب وكبار السن، بل إن ذلك يجعل الثباب أكثر فخرا بقيمهم وتاريخهم وتر اثهم، و هي جميعا مكونات أساسية للهوية الوطنية. وقد أشنارت إحدى الدراسات بأن ثمة إجماع بين الخبر اء على أن تحقيق الأنشطة الجامعية لدورها في تعزيز قيم الانتماء والمواطنة في نفوس الطلاب يتطلب توافر عدد من المقومات هي:(^) 
د. ولاء السيد عبد الله السيد صقر د. يحيى مصطفى كمال الدين

- - أن تؤكد الجامعة على أن الأنشطة الطلابية تساعد الطلبة على حسن تقدير هم لوطنهم. - - أن تسعى الجامعة لجعل الطلبة يدركون المقومات الثقافية والجغرافية والطبيعية و الاقتصادية و الحضارية لوطنهم. - أن تمكن الأنشطة الطلاب من إدر الك مكانة وطنهم محلياً و إقليمياً و عالمياً. - أن توضح الأنشطة الجامعية للطلاب قيمة وأهية المشاركة المجتمعية في بناء الوطن. - أن تدعم تلك الأنشطة وعي الطلاب بالحقوق و الواجبات الوطنية. - أن تمكن الأنشطة الطلاب من استشعار المسؤولية تجاه وطنهم في حمايته والزود

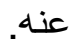
- أن تحتم الأنشطة الجامعية ضرورة تعامل اللاب الإيجابي مع الأنظمة والقوانين الوطنية. - أن تُعد تلك الأنشطة الطلاب ليكونوا قدوة في التمثل الأخلافي بشخصية وطنه. - أن توفر الأنشطة للطلاب التدريب الكافي على أهمية العمل المشترك والفاعل رسمياً وتطو عياً.

ويرى الباحثان من خلال عرضهما للإطار النظري أن هناك مجموعة من النقاط الهامة التي ينبغي الإشـارة إليها وهي: - أن مفهوم الهوية الوطنية يتشكل من عنصرين أساسيين هما الهوية بمقوماتها الثناث الأساسية من حيث الكيان ذاته وتتخيصه و الوجود الخارجي الذي ينواجد فيه، و الوطنية بارتباطها بالمواطنة القائمة على معرفة الواجبات والتزامها، و الحقوق و العمل في ضوئها. 
أثر برنامج إثرائي قائم على معايير العلوم اللجيل القادم (NGSS) في تنمية مهارات القرن الحادي والعشرين ونزء ات التفكير لاى طلاب الصف الثالث المتوسط المتفوقين ذوي المستويات المختلفة في معالجة المعلومات

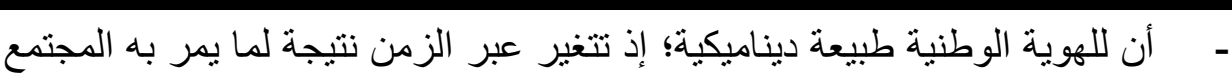
من تحولات، تظهر آثارها بوضوح في كل من الثخصية والثقافة الوطنية ل المجنمع.

- أن للهوية الوطنية مقومات أربع أساسية تشكل القواعد الأساسية التي يقوم عليها بناء الهوية وهي: اللغة والمعتقد والتاريخ المشترك و التراث الوطني، أذا تلعب تللك المكونات الأربع دوراً جليا في تحقيق لُحمة المجتمع وتماسكه والتفافه حول تاريخه المشترك، وعنايته بتراثه الذي هو مخزونه القيمي، و التزامه بدينه الذي يضبط معاملاته و أخلاقه، ولغته التي يتفاهم بها أبناء المجتمع الو احد ويتو اصلون. أن للهوية الوطنية وظائف عديدة يمكن إجمالها في حماية الثخصية المجتمعية من عوامل الذوبان والثتات، وأنها كلما كانت قوية كانت أكثر فاعلية في تماسك المجتمع ورفعته ونهضته. - ان. - - أن للجامعات إضافة إلى أدوارها التعليمية والبحثية والخدمية، أدوار أخرى في تعزيز الهوية الوطنية، تتجلى في تعزيز المسؤولية المجتمعية في نفوس الطلبة ليكونوا عناصر فاعلة في مجتمعاتهم، وأن تعمل على غرس الانتماء لوطن في نفوس أبنائها من الطلبة. - أن تحقيق الجامعة لدورها في تعزيز الهوية الوطنية، يتأتى من خلال وسائط مختلفة منها: توظيف المقررات الدراسية في توضيح ماهية الهوية الوطنية وأهميتها وضرورة الحفاظ عليها والتعريف بتاريخ الوطن وتر اثه، والتأكيد على لهي التدريس باللغة القومية باعتبارها إحدى مكونات الهوية الوطنية، وأن يكون أعضاء هيئة التدريس نماذج للهوية الوطنية من خلال سلوكياتهم ووسطيتهم وقبولهم للر أبي والر أي الآخر، كما يمكن للجامعة أن توظف الأنشطة المختلفة التي يقوم بها الطلاب داخل الجامعة في استكثافهم لهويتهم الوطنية، وترسيخها في

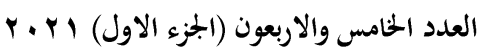
$(360)$ مجلة كلية التربية- جامعة عين شمس 
د. ولاء السيد عبد الله السيد صقر د. يحيى مصطفى كمال الدين

نفوسهم و الذود عنها أما ما يعصف بمجتمعاتنا وشبابنا من تيار ات فكرية وتثوينية هدامة.

القسم الثاني: الواقع الراهن لوسائط الجامعات المصرية في تنمية الهوية والوطنية والقوى والعوامل الثقافية المؤثرة عليها.

تناول هذا القسم وصف الواقع الراهن لوسائط الجامعات المصرية في تتمية الهوية و الوطنية والقوى و العو امل الثقافية المؤثرة عليها، وسيم ذلك وفقاً للمحاور التالية: أولاً: نبذة مختصرة عن الواقع الراهن للجامعات المصرية:

يعتبر التعليم الجامعي الخطوة الرسمية والمؤسسية الأخيرة في تشكيل مهارات

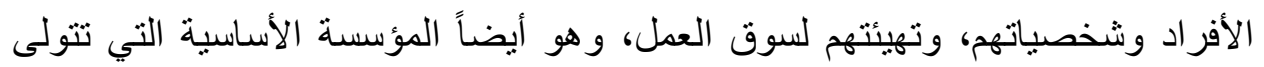
تخريج الكوادر البشرية ذات المهارات العالية، التي يجري الاعتماد عليها في جميع المجالات، وقد أولت الدولة اهتماماً كبيراً بقطاع التعليم العالي، فقد زادت الجامعات

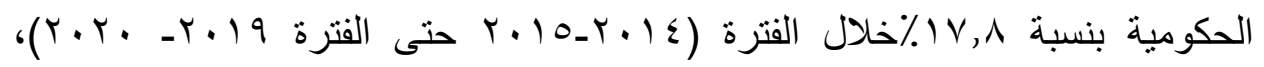
ليصبح إجمالي الجامعات الحكومية YV جامعة، بينما زادت الجامعات الأهلية الخاصة

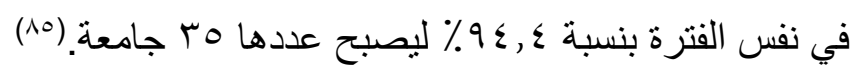
ويعتمد القبول بالغالبية العظمى من الجامعات المصرية، على مجموع الطالب في امتحان إتمام مرحلة التعليم الثانوي، الذي يعقد سنوياً، وتشرف على انعقاده وزارة التربية والتعليم، ويمكن للطلاب الذين يجتازون هذا الامحان بنجاح، أن يتقدموا لشغل أماكن بالجامعات المصرية عن طريق مكتب التنسيق المركزي، وهو المكتب الذي يتولى

توزيع الطلاب على مؤسسات التعليم العالي المختلفة، وفقاً لعدد من المعايير هي:(بهرئ • الحد الأقصى لعدد الطلاب المقرر قبولهم في كل مؤسسة من مؤسسات التعليم العالي، و التي يقرر ها كل من وزارة التربية والتعليم، المجلس الأعلى للجامعات. • ترتيب مجاميع الطلاب المرشحين الر اغبين في القيد ببر امج التعليم العالي. ترنيب رغبات الطلاب المرشحين.

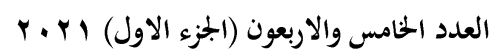

(361)

مجلة كلية التربية- جامعة عين شمس 
أثر برنامج إثرائي قائم على معايير العلوم اللجيل القادم (NGSS) في تنمية مهارات القرن الحادي والعشرين ونزء ات التفكير لاى طلاب الصف الثالث المتوسط المتفوقين ذوي المستويات المختلفة في معالجة المعلومات وتتلخص استر اتيجية التعليم العالي في العقد الحالي في عدد من النقاط تركز على: إتاحة التعليم العالي للجميع دون تمييز، وتحسين جودة النظام التعليمي بما يتفق مع النظم العالمية، وتحسين تنافسية نظم ومخرجات التعليم(AY)، الأمر الذي يوضح أن أبواب مؤسسات التعليم العالي المصرية مفتوحة على مصر اعيها للمتقدمين للالتحاق بها، مما يدل على أن هناك عدداً ليس بالقليل من أبناء المجتمع المصري، يشكلون جزءاً من منظومة التعليم العالي، وخاضعين لما يُقدمه من أفكار، تسهم في بناء عقليتهم وشخصيتهم، مما يترتب عليه توجيه الأنظار لما يمكن أن تقدمه الجامعة للنهضة بعقليات طلابها، وبناء شخصياتهم الوطنية. كما أكدت وزارة التعليم العالي والبحث العلمي والتكنولوجيا على أن دور الجامعات في خدمة المجتمع يجب أن يركز على بناء شخصية الطلاب الجامعيين وترسيخ مبادئ الهوية الوطنية في أذهانهم، الاهتمام بتو عيتهم سياسياً( (A))، وجدير بالذكر في هذا الصدد أن أعداد الطلاب المصريين المقيدين بالمرحلة الجامعية الأولى بمؤسسات التعليم العالي يقدر بحالي Y, مليون طالب وفقاً لتعداد عام

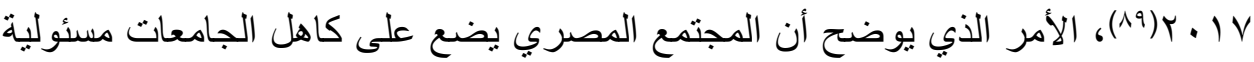
التشكيل النهائي لعدد ليس بالقليل من شبابه لمواجهة التحديات العالمية الآنية والمستقبلية التي يجب أن يتسلح الثباب لمواجهة آثنار ها السلبية. ثانياً: وسائط الجامعات المصرية في تنمية الهوية الوطنية لاى طلابها: تمت الإشارة فيما سبق إلى أن للجامعة دور لا يمكن إغفاله في تشكيل ودعم الوعي الطلابي؛ ولقد أثبت الدراسات، أن للجامعة دور واضح في إعداد الطلاب للمواطنة الصالحة، والتأثثر على قيمهم ومعتقداتهم، إلا أن هذا التأثير يُعد انعكاسًا لما تقوم به السلطة الحاكمة في المجتمع من ممارسات على السلطة داخل الجامعة. ولما كانت المرحلة الجامعية تُعد مرحلة النضج واكتمال الثخصية، فإنه على الجامعات أن 
د. ولاء السيد عبد الله السيد صقر د. يحيى مصطقى كمال الدين

تستثر هذه المرحلة في بناء الثخصية القوية التي تسنطيع أن تتفاعل مع الانحر افات و القيم الفاسدة، بطريقة تَفِيَها شرّ الوقوع في براثنها، والعبور بالوطن إلى برّ الأمان،

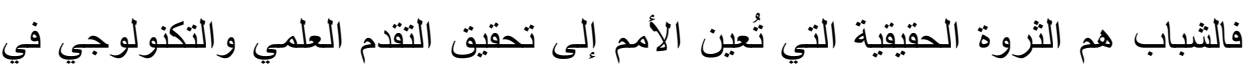
ضوء المتغيرات العالمية التي تسود العالم وتجعل من يمتلكها هو الأقدر على قيادة من حوله.

ولقد قامت الجامعات المصرية بالعديد من الممارسات والجهود لتشكيل وعي الطبة وتعزيز قيم الولاء والانتماء لديهم، والحفاظ على الهوية الوطنية لهم، إلا أن هنالك بعض جوانب القصور في تللك الجهود إضافة إلى بعض السلبيات التي انعكس أثرها على إلى الته الهوية الوطنية لطلبة الجامعات المصرية، وسوف يعرض الباحثان لواقع الجامعات المصرية في ظل المحاور الأساسية للبحث. 1. تعزيز تعلم اللغة القومية والتعليم بها.

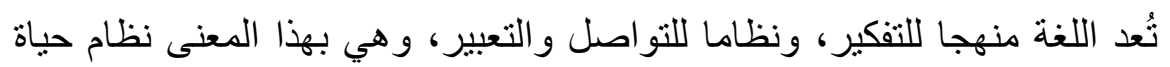

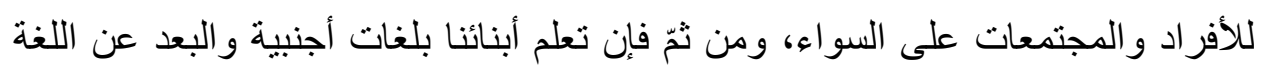

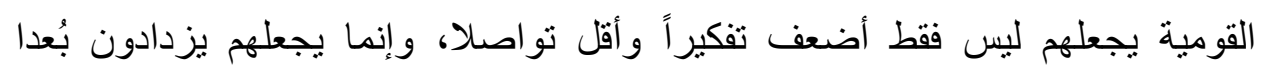

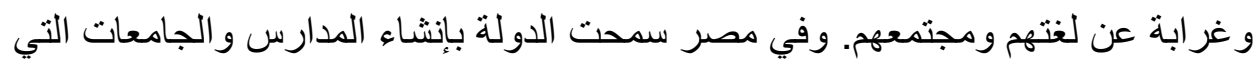
ثُقدم برامجها التعليمية بلغات أجنبية، وهو أمر تحرمه كثير من الدولة حفاظاً على

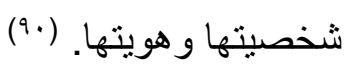
وفي مصر يؤثر ضغط اللغات الأجنبية في المدارس والجامعات على اللغة العربية ويُقلص من نفوذها، ويجعل المجتمع يعاني من غياب الثقافة الوطنية التي هي جزء من هوية الأمة، مما يحرم المجتمع من مجرد التفكير بضرورة النهضة ويجعلنا

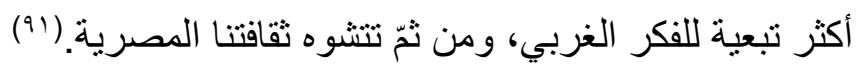


أثر برنامج إثرائي قائم على معايير العلوم اللجيل القادم (NGSS) في تنمية مهارات القرن الحادي والعشرين ونزء ات التفكير لاى طلاب الصف الثالث المتوسط المتفوقين ذوي المستويات المختلفة في معالجة المعلومات

و على الرغم مما تؤكد عليه الدولة المصرية من أهمية الحفاظ على الثقافة الوطنية و التأكيد على الذاتية العربية والإسلامية للثخصية المصرية، وغرس الانتماء الوطني في نفوس الطلاب، إلا أن الو اقع يتناقض مع ما تنادي به الدولة.(rو) إذ يوجد في مصر عدد من الجامعات الأجنبية التي تدرس برامجها بغير اللغة العربية، كما أن منهاجها ومقرر اتها التدريسية تخضع للمعايير الخاصة بتلك الجامعات دون تدخل من وزارة التعليم العالي المصرية، وهذه الجامعات هي: الجامعة الفرنسية و الجامعة الألمانية والجامعة البريطانية، والجامعة المصرية الروسية و الجامعة المصرية الصينية، كما توجد جامعة الأهر ام الكندية (ب9هن. كما أن الكثير من الكليات بالجامعات المصرية تقدم برامجها باللغتين العربية و الإنجليزية، فعلى سبيل المثال بجامعة عين شمس وهي واحدة من أعرق الجامعات المصرية، تدرس كلية التربية برنامج البكالوريوس في العلوم والتربية في تخصصات الرياضيات والبيولوجي والجيولوجيا والفيزياء باللغتين العربية والإنجليزية.(؟9) كما تدرس كلية الحقوق برنامجين أحدهما باللغة الإنجليزية والآخر باللغة الفرنسية.(90) كما وليأ أنه في كلية التجارة يوجد برنامجين للاراسة أحدهما بالغة الإنجليزية والآخر باللغة الفرنسية إلى جانب برنامج للشر اكة و المعروف باسم "كيين" بين كلية التجارة جامعة عين شمس وكلية أوشن وجامعة كين الأمريكية. (T9) ومن ثمّ فأن التدريس بلغة مغايرة للغة العربية التي هي اللفة الأم للدولة المصرية يكون له الأثر السلبي على انتماء الطلاب للهوية والثقافة العربية، ناهيك عن أن هذه البرامج تساعد على نشر الثقافة الأجنبية واستقطاب انتماء الطلاب لتلك الثقافات

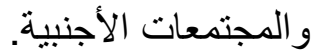
وهو ما أكدت عليه الدراسات من أن التدريس باللغات الأجنبية قد كرس الولاء للتقافات الأجنبية لاى بعض الطلاب، وبالذات هؤلاء الذين أتوا الى الجامعة من 
د. ولاء السيد عبد الله السيد صقر د. يحيى مصطفى كمال الدين

مدارس اللغات الأجنبية؛ فقد أصبح المستقبل العلمي للطالب بأكمله مرتبطاً بالثقافة الأجنبية، وأصبحت نوجد داخل الجامعة مجموعات من الطلاب الذين يدينون بالولاء للثقافة الفرنسية ويدرسون في أقسام اللغة الفرنسية ومن الطلاب الذين يدينون

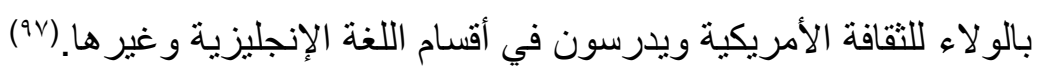
ومما سبق يتضح أن هناك عدد من الممارسات الجامعية التي يغلب فيها التدريس بغير اللغة القومية واللجوء إلى اللغات الأجنبية سواء أثناء تدريس بعض المقررات، أو من خلال برامج در اسية كاملة، الأمر الذي يُساهم بدرجة كبيرة في انحسار اللغة العربية في الدراسة الجامعية وذلك بهيمنة اللغات الأجنبية تارة، والتحدث باللهجة العامية تارة أخرى، الأمر الذي تتعكس أثاره على ضعف الثقافة الوطنية نتيجة لضعف اللغة القومية التي هي جزء من هوية الأمة.

كما أن تدريس بعض البرامج الجامعية باللغات الأجنبية، يشعر الطلبة بهيمنة

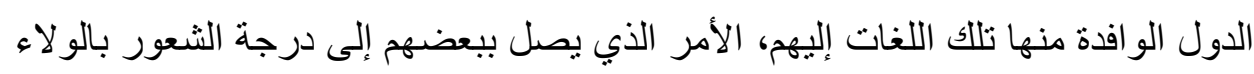

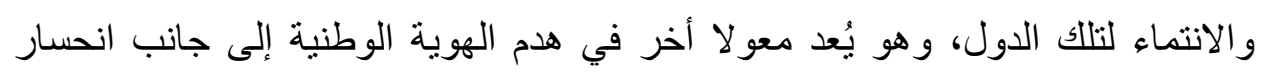
اللغة القومية.

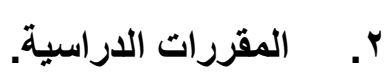

تعمل الجامعات المصرية على تعزيز الهوية الوطنية لطلابها من خلال ما تقدمه من مقررات عبر بر امجها الدر اسية المختلفة، سواء أكان ذلك من خلال مقررات دراسية

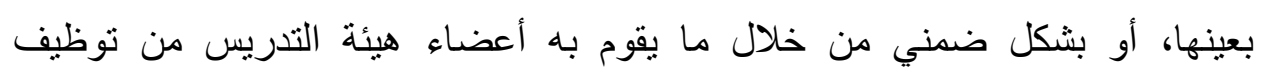

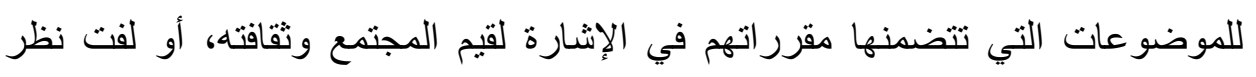
الطلاب إلى ارتباط مسألة ما بتاريخ مصر القديم أو الحديث، إذ على سبيل المثال يشير الإنير بعض أعضاء هيئة التدريس الذين يقومون بتدريس نظرية فيثاغورث في علم الرياضيات، إلى أن فيثاغورث استقى نظريته تللك من علم القياس الذي كان يستخدمه المساحون المصريون في طيبة في مصر الفرعونية.

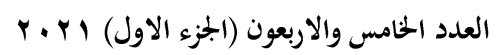

(365)
مجلة كلية التربية- جامعة عين شمس 
أثر برنامج إثرائي قائم على معايير العلوم اللجيل القادم (NGSS) في تنمية مهارات القرن الحادي والعشرين ونزء ات التفكير لاى طلاب الصف الثالث المتوسط المتفوقين ذوي المستويات المختلفة في معالجة المعلومات

و على الجانب الآخر تعمل الجامعات المصرية على تعزيز الهوية الوطنية من لهن

خلال تدريس عدد من المقررات ذات الارتباط بالقيم التي يتبناها المجتمع المصري وتشكل جزءً لا يتجزأ من الهوية الوطنية للمجتمع، ومن هذه المقررات مقرر حقوق الإنسان.

\section{تذريس مقرر حقوق الإنسان.}

دفع الاهتمام الدولي بتدريس حقوق الانسان الكثير من الجامعات والمنظمات الإقليمية ومنظمات المجتمع المدني إلى تبني برامج تدريسية وتدريبية تتناول كافة الجو انب الأساسية لحقوق الإنسان في كافة المستويات التعليمية، ولقد رأت منظمة الأمم المتحدة للعلوم والتربية والثقافة (اليونسكو) أن تعليم حقوق الإنسان ينبغي ألا يقتصر على الجانب المعرفي المتصل بالمبادئ الرئيسية لأبرز الحقوق والآليات المستخدمة لحماية تللك الحقوق، و إنما ينبغي أن يمتد ليشمل الجانب القيمي المتمثل في القيم و الاتجاهات التي تُعلي من شأن حقوق الأنسان وتعمل على دعمها، كما ينبغي أن تستهدف هذه المقررات الجانب السلوكي في صورة أنماط السلوك المكتسبة التي تؤدي إلى عمل دؤوب ونشاط دائم من أجل الترويج لقضايا حقوق الإنسان و الدفاع عنها.(9^) ولتحقيق ذلك فإن جل مقررات حقوق الإنسان في الجامعات الكبرى بالعالم اتسمت بجملة من السمات التي تتفق مع رؤية اليونسكو وغيرها من المنظمات الدولية والمتمثلة في جوانب ثلاث أساسية هي: مضامين المقررات بحيث تشمل موضوعات مختلفة من بينها حقوق الأنسان والمواطنة، وطرق التدريس بحيث لا تقتصر على المحاضرات، وإنما تمتد لتشمل دراسات الحالة وقراءة التقارير الدولية وغيرها، ووسائله لتشمل

التقارير و الأفلام الوثائقية و الوثائق الدولية وغبر ذلك من الوسائل.(99) وفيما يتعلق بتدريس المقرر في الجامعات المصرية، فقد كان لكلية الاقتصاد والعلوم السياسية بجامعة القاهرة السبق في هذا الأمر بإدخال مقرر منفصل لحقوق الإنسان ضمن مقررات قسم العلوم السياسية بالكلية وكان ذلك في أوائل الثمانينيات من 
د. ولاء السيد عبد الله السيد صقر د. يحيى مصطفى كمال الدين

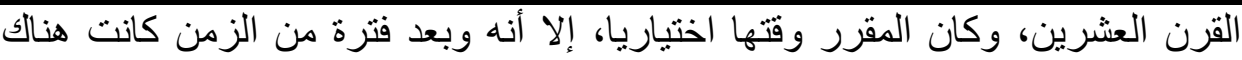
دعوات إلى أن يكون المقرر إجباريا على كافة طلاب الجامعة بالفرقة الأولى بجميع الكليات، وربطه بمو اد مكملة عن التربية على المواطنة والمشاركة السياسية. وفي أواخر التسعينيات ومطلع القرن الحادي والعشرين أقر المجلس الأعلى للجامعات المصرية تدريس مقرر حقوق الإنسان كمقرر إجباري على طلاب الجامعات المصرية، وقد تفاوتت الجامعات في مضامين المقرر وطرق تدريسه. (..') وبعيدا عن المقررات المباشرة والتي تعمل على تعزيز القيم و العادات والثقافة للمجتمع المصري، نجد أن الغالبية العظمى من أعضاء هيئة التدريس بالجامعات المصرية، يركزون على المحتوى الأكاديمي التخصصي للمقررات الدراسية المقدم للطلاب، غافلين عن الدور الأساسي للجامعة في تنمية القيم والأخلاقيات التي يرتضيها المجتمع المحلي والعالمي، والتي تُعد طالب اليوم للتعامل بإيجابية مع احتياجات عالم

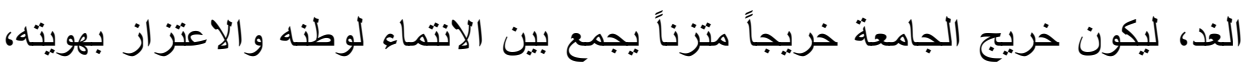
قادراً على التوصل مع مجتمعه العالمي والاندماج فيه، مستفيداً من عضويته بالمجتمع التهاه العالمي، في إثر اء و اقعه المحلي، ووطنه الأم. ولعل غياب دور عضو هيئة التدريس عن هذا الإعداد في شخصية الطلاب، انعكس بشكل واضح على غياب العديد من القيم المحلية الداعمة لانتماء الثباب الجامعي

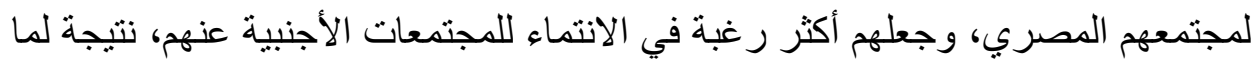
تكوّن لديهم من قناعات بتفوق تلك المجتمعات، وقدرتها على تحقيق الأفضل للمجتمع العالمي ككل، نظراً لأنها تعبر عن ثقافات وكيانات متقدمة، وذات وزن مقارنة بأوضاع المجتمع المصري، ويمكن تلخيص الأسباب الأساسية التي ساهدت في خلق هذا المناخ السلبي الذي أسهم في إضعاف انتماء خريجي الجامعات المصرية للوطن الأم إلى: (1.1) محدودية وجود مقررات خاصة بالتوجيه القيمي والإرشاد الخلقي. 
أثر برنامج إثرائي قائم على معايير العلوم اللجيل القادم (NGSS) في تنمية مهارات القرن الحادي والعشرين ونزء ات التفكير لاى طلاب الصف الثالث المتوسط المتفوقين ذوي المستويات المختلفة في معالجة المعلومات

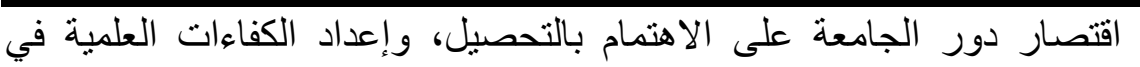
مختلف التخصصات الأكاديمية. التقيد بمناهج ومقررات محددة لإعداد الطلاب فيها وفقاً لتخصصات أكاديمية معينة.

كثرة عدد الطلاب مما يصعب الأمر على أعضاء هيئة التدريس للمناقثنة و التفاهم مع الطلاب حول الوضع القيمي المطلوب، وسبل تنمية الانتماء لدى الطلاب، وأهمية الانتماء للوطن الأم في مقابل الثقافات الأخرى التي يرون أنها أكثر تقدماً. آثار الاستعمار الغربي والضغوط السياسية التي ساهمت في تحييد دور الجامعة إزاء التنشئة والتنمية الخلقية وتربية الطلاب على التمسك بقيم الولاء و الانتماء و التمسك بالهوية الوطنية للمجتمع الأم. r. - الأنشطة الطلابية الجامعية. تنوعت الأنشطة الطلابية التي قامت بها الجامعات المصرية من أجل تعزيز الهوية الوطنية لطلبتها ومن هذه الأنشطة: أ- تنظيم المؤتمرات والندوات والمعارض العلمية: تعد المؤتمرات العلمية والندوات التثقيفية والمعارض، من أهم الوسائل التي تسنطيع الجامعة من خلالها التأثير على الطلاب، فمن خلالها تنشأ علاقة مباشرة بين الطلبة والمشاركين في تلك المؤتمرات والندوات، ومن خلال الحوار الذي ينشأ بين الطلبة والقائمين على موضوع الندوة تحدث الاستفادة وذلك إما بتغيير قناعات خاطئة و اكتساب أخرى سليمة، أو بالوصول على منطقة وسط حول قضايا بعينها، أو تعديل سلوك كان قد تكون بطريقة خاطئة في مرحلة التنشئة، ولكن للقيام بهذه الندوات مجموعة من الثروط التي يجب نو افر ها حتى يتحقق الهدف منها وهي: (ץ.1)

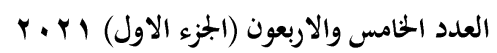

(368)
مجلة كلية التربية- جامعة عين شمس 
د. ولاء السيد عبد الله السيد صقر د. يحيى مصطقى كمال الدين

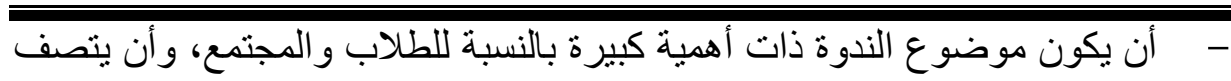

$$
\text { بالبساطة و الوضوح في الحوار. }
$$

- - أن تتناول الندوة بعض المشكلات السائدة في المجتمع وتقديم الحلول لها. - - أن يتم إثر الك الطلاب في الندوة من خلال الحوار المتبادل مع المحاور، و التأكيد على الإعلان عن الندوة قبل الانعقاد بوقت كاف. ومن بين الندوات و المؤتمرات التي عُقدت معرض فني مصر عن ثورة الخامس و العشرين من يناير ، و الذي نظمه اتحاد الطلاب بكلية الآداب جامعة بني سويف.(r. ()

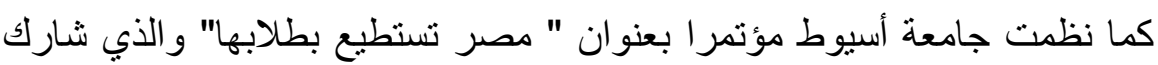

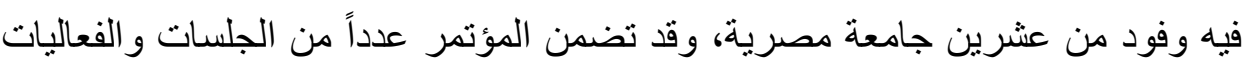
العلمية والثقافية والفكرية التي تهدف إلى إتاحة المجال أمام الطلاب المهتمين بقضايا وطنهم ومجتمعه، في للتعرف على رؤية شباب الجامعات المصرية حول آليات تطوير التعليم الجامعي والأنشطة والخدمات الطلابية والاستفادة من تللك الأفكار والرؤى بعرضها على صناع القرار في مجال التعليم، بالإضافة إلى سعى المؤتمر إلى ربط الثباب بمشاكل التعليم الجامعي في مصر وسبل تطويره.(๕.) ومثل هذه الفعاليات الطلابية من معارض ومؤتمرات وندوات، يكون لها الأثر الإيجابي في نفوس الطلاب، إلا أن المشكلة الكبيرة التي تواجه مثل تلك الفعاليات، هو هون انشغال الطلاب عنها أحيانا بدراستهم ومحاضر اتهم، أو بغيرها من الأنشطة الأخرى التي تستهويهم.

\section{ب- أنشطة الاتحادات والجماعات الطلابية.}

تُعد الاتحادات الطلابية بمثابة البرلمان الذي يستطيع الطلاب من خلاله التعبير

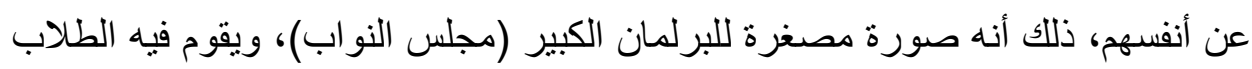
بمناقتة القضايا التي تتعلق بحياتهم الأكاديمية الجامعية بطريقة راقية وفق أسس وأساليب ديمقر اطية، الأمر الذي يُؤصل مبادئ الممارسة الديمقر اطية في سلوكياتهم، كما يندربون لئه

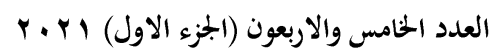

(369)
مجلة كلية التربية- جامعة عين شمس 
أثر برنامج إثرائي قائم على معايير العلوم للجيل القادم (NGSS) في تنمية مهارات القرن الحادي وإعشرين

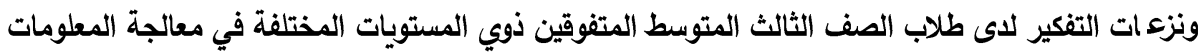

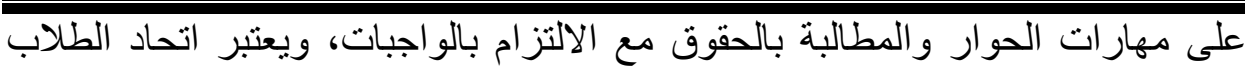
من أهم الجماعات التي تتكون داخل الجامعة عن طريق الانتخاب و الذي يستطيع الطلاب أن يحققوا ذاتهم من خلاله و الحصول على حقوقهم.

ويتكون اتحاد الطلاب بالجامعة عن طريق الانتخاب الذي يتم بين الطلاب ويشرف عليه مجموعة من الأساتذة مع رعاية الثباب وشئون الطلاب وينتكل من مجلس اتحاد الطلاب والمعرف بمسمى المكتب التنفيذي، إضافة إلى رؤساء جماعات الأنشطة الثقافية، و الاجتماعية، والعلمية، والفنية، والرياضية... الخ يتم اختبار هم من أعضاء الاتحاد، وأحد الأساتذة الذي يقوم بالإشراف على الاتحاد ويكون الأمين العام للاتحاد وعادة ما يكون عميد الكلية أو أحد الوكلاء. وتكون مدة الاتحاد الطلابي عام دراسي واحد ينتهي مع انتهاء العام الدراسي ليتشكل الاتحاد الجديد مع بداية العام

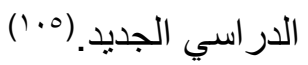

ويقوم اتحاد الطلاب بالعديد من الأنشطة الثقافية والعلمية والفنية والرياضية التي

يتم فيها الاستعانة بالطلاب المتميزين في كل نشاط من الأنشطة السالفة، وتوجهه التوجيه الصحيح وغرس القيم، والتقاليد والعادات السائدة، ويكون له دور و اضح في القيام بعقد المؤتمرات والندوات العلمية التي تتم داخل الكلية حول الموضوعات ذات التأثنر عليهم. (1. (1) حيث نظم اتحاد الطلاب بجامعة الزقازيق مؤتمر ا علميا لطلبة قسم الكيمباء بكلية الصيدلة في الثاني والعشرين من نوفمبر لعام V V. P وقد حضر هذا المؤتمر أعضاء هيئة التدريس و الطلاب بالقسم، ودارت أحداث المؤتمر ووقائعه في جو من اللفة والتبادل المعرفي بين الطلبة وأعضاء هيئة التدريس، الذين أجابوا عن أسئلة الطلبة

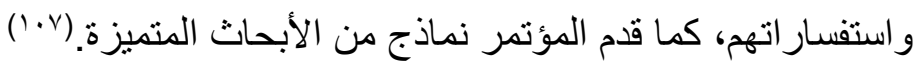


د. ولاء السيد عبد الله السيد صقر د. يحيى مصطفى كمال الدين

وتعد مثل هذه اللقاءات العلمية التي تجمع بين أعضاء هيئة التذريس و الطلاب بالجامعة، فرصة للحوار وتبادل الفكر، و الوقوف على الإنجازات العلمية لأعضاء هيئة

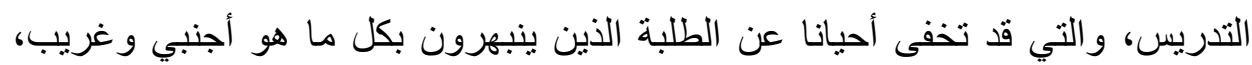
مما يجعلهم يستشعرون قيمة المواطن المصري، و إنجاز اته رغم قسوة الظروف أحيان وقلة الإمكانيات.

\section{ج- المسرح التربوي.}

يلعب المسرح التربوي دوراً بارزاً في تعزيز الانتماء وتحقيقه، إلا أن ذلك لا يتحقق إلا بالتكامل مع المناهج والأساليب التربوية التي تعمل في نوافق من أجل التنمية الثاملة للفرد، وهو الهدف الأساسي للتربية، والتي تضع نصب عينبها هدف بناء شخصية الطالب، وهذا الهدف يحتم وجود منهج دراسي من مواد، و أدوات، وينفذ من خلال طرق تدريس، ووسائل تعليمية، و أبنيه تعليمية ومناخ ديمقر اطي يشمل الحوار بين دين

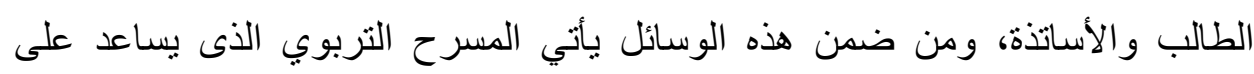

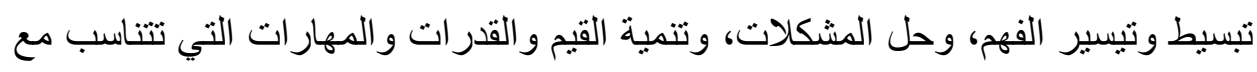
بعض عناصر المنهج الذى يسعى إلى تحقيق الهدف العام وهو إعداد المواطن

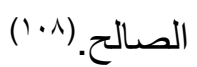

ومن خلال المسرح التربوي يستطيع الطلاب إثباع بعض رغباتهم والتعبير عن آرائهم، والتأثنر في قيم وأفكار زملائهم بطريقة مباشرة وشيقة، لأن الذين ساهموا في إعداد المسرحية بهدفون إلى أن يصل الهدف أو الغرض من المسرحية لزملائهم، لذا فإنه عن طريق المسرح يمكن تغيير الفهم وإثارة حسن الاستطلاع، وتغيير القيم الخاطئة عند

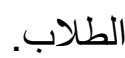

وفي دراسة أُجريت عن القضايا الاجتماعية في دراما المسرح الجامعي المصري

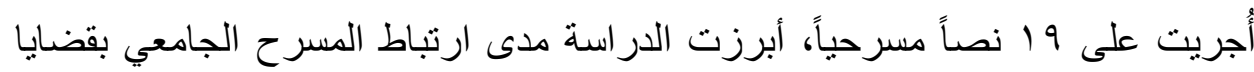
المجتمع الآنية، فجاء الخطاب المسرحي منتقًا بشدة لبعض القضايا الاجتماعية كسيطرة

$$
\begin{aligned}
& \text { العدد الحامس والاربعون (الجزء الاول) ب. r. T } \\
& \text { مجلة كلية التربية- جامعة عين شمس }
\end{aligned}
$$


أثر برنامج إثرائي قائم على معايير العلوم اللجيل القادم (NGSS) في تنمية مهارات القرن الحادي والعشرين ونزء ات التفكير لاى طلاب الصف الثالث المتوسط المتفوقين ذوي المستويات المختلفة في معالجة المعلومات

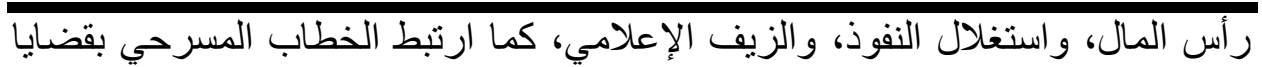
المجتمع العربي عامة باعتباره الكيان الأكبر للأمة العربية، فطرحت دراما المسرح الجامعي قضايا: كالوحدة العربية، وقضية فلسطين، والحرب على العراق، كما في مسرحيات العادلون، وباب الفتوح، وإسطبل عنتر، كما ركزت بعض عروض المسرح الجامعي على قضايا اجتماعية كالحرية، والعدالة، وفساد رجال السلطة، والاغتراب و الانتماء، وفقدان الهوية الثقافية. (1.)

وبرؤية تحليلية لجهود الجامعات المصرية في تعزيز الهوية الوطنية لطلبتها، يمكن الوقوف على النقاط التالية: - - أنه على الرغم من قيام الجامعات المصرية بتدريس مقررات من شأنها تعزيز الهوية الوطنية لطلبة الجامعة، إلا أنها أخفقت في تحقيق الهدف المنشود من تدريس تللك المقررات بتأكيدها على الجوانب النظرية للمحتوى العلمي، و التركيز على التحصيل المعرفي أكثر من المهاري والقيمي، كما غابت عن البرامج الجامعية المقرر ات التي تخدم تعزيز الجانب القيمي والأخلافي للمجتمع المصري. - أن الجامعات المصرية قدمت أنشطة منتوعة لتعزيز الهوية الوطنية لطلبتها ومنها المؤتمرات العلمية والندوات التثقفية كمؤتمر مصر تستطيع بطلابها، ومعرض ثورة الخامس والعشرين من يناير ، إلا أنه ومع إقامة مثل هذه الفعاليات والأنشطة الجامعية، نجد أنها غير كافية مقارنة بأعداد الطلبة بالجامعات، وما يتعرضون له من موجات عارمة من التغيير التقافي. كما أن أنشطة الاتحادات الطلابية التقافية و الفكرية والعلمية، إضافة إلى أنشطة المسرح التربوي، هي الأخرى لا تشكل سوى قطرة في بحر من الأنشطة الترفيهية التي لا تخدم قضية الهوية الوطنية، والتي أحياناً ما تنافي القيم و المعتقدات والأخلاقيات التي يؤمن بها المجتمع المصري. 
- - أن التغيرات السياسية التي مرّ بها المجتمع المصري خلال السنوات العشر السابقة كان لها أثرها الو اضح في تشكيل رؤى الثباب عن مجتمعهم بصورة متناقضة ما بين راض ورافض لما يتم على أرض الوطن، الأمر الذي انعكس سلباً على تمسكهم بهويتهم الثقافية، بل والبحث عن قدوة ثقافية أخرى، يظنون أنها الأفضل من وجهة نظر هم ليكونو ا تابعين لها بدلاً من تبعيتهم الثقافية للمجتمع المصري. - - أن المتغيرات الاقتصادية التي عصفت بالمجتمع المصري، دفعت الثباب إلى

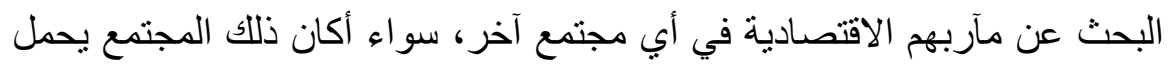
ذات المكونات الثقافية للمجمع المصري أم لا، الأمر الذي من شأنه التأثير على الثى الهوية الوطنية لهؤلاء الثباب. - - أنه على الجامعات المصرية بذل المزيد من الجهود لتعزيز الهوية الوطنية للمجتمع المصري وتكريس كافة الجهود والموارد المتاحة بالجامعة لذللك، والتأكيد على القيم و المرتكز ات الثقافية التي تدعم الثخصية القومية المصرية. ثالثاً: القوى العوامل الثقافية المؤثرة على وسائط الجامعات المصرية في تنمية الهوية الوطنية لطلابها:

شهدت الآونة الأخيرة بجمهورية مصر العربية عدداً لا يستهان به من التغيرات المجتمعية المختلفة على كافة الأصعدة السياسية والاقتصادية والاجتماعية، نتيجة لآثار الثورات المتتالية التي شهدتها الساحة العربية بوجه عام، وجمهورية مصر العربية على وجه الخصوص، فالتغيرات السياسية التي قفزت على الساحة، كان لها أثراً بالغاً في لهي إعادة تثكيل الواقع السياسي، و علاقات الدولة بغيرها من الدول المحيطة، كما كانت لها أثر لا يستهان به في إعادة تشكيل عقليات الثباب على وجه الخصوص، على اعتبار

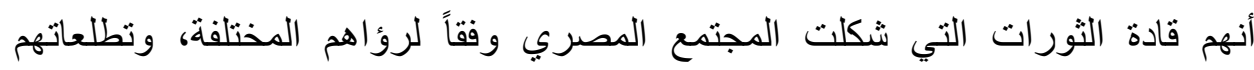
المستقبلية بشأن المجتمع، فكان لبعضهم وجهة نظر إيجابية ومحايدة في نظرته للمجتمع المصري بالرغم مما يعانيه من مشكلات على الساحة السياسية، وكان للبعض الآخر 
أثر برنامج إثرائي قائم على معايير العلوم اللجيل القادم (NGSS) في تنمية مهارات القرن الحادي والعشرين

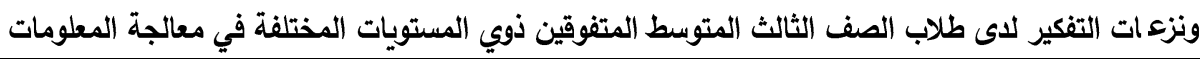

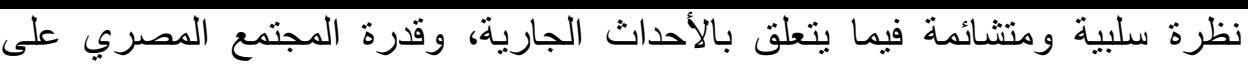
النهوض و الصمود أمام كافة المتغير ات و التهديدات و التحديات التي يو اجهها في ظل كافة الظروف المجتمعية الحالية، الأمر الذي انعكس سلباً على قدرة هذه الفئة من الثباب على الاستمر ار في التمسك بهويتهم الوطنية، وثقافاتهم القومية المصرية، بل و التوجه في أسوأ الظروف للبحث عن قدوة ثقافية أخرى، يظنون أنها الأفضل من وجهة نظرهم ليكونوا تابعين لها بدلاً من تبعيتهم الثقافية للمجتمع المصري، مما يترتب عليه ضرورة تنبه المؤسسات التعليمية بشكل عام، والجامعات بشكل خاص، لدورها في إعادة استقطاب تللك الفئة، وتدعيم إعادة انتمائهم للمجتمع المصري على الرغم مما يعانيه من مشكلات

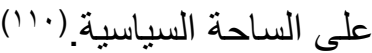
كما أن تدهور الأحوال الاقتصادية، وأزمة ارتفاع الأسعار، كان لها الأثر السلبي على علاقة الثباب بمجتمعه الأم، إذ أن سوء الأحوال الاقتصادية للشباب المصري، كان له نتائج انعكست على رغبتهم في البحث عن مآربهم الاقتصادية في أب مجتمع آخر، وتكمن الخطورة هنا في أن المجتمع الذي يستطيع أن يلبي لهؤلاء الثباب مطالبهر الاقتصادية، أصبح هو الحلم والمقصد لدى الغالبية العظمى من الثباب، مهما كانت أغر اضه الخفية من وراء تلبية تللك الأغراض الاقتصادية، والتي قد لا تكون أغر اضاً بريئة في معظم الأحيان، ومن ثم أصبح الثشاب مستعداً للتخلي عن انتمائه وهويته لمجتمعه الأم في مقابل توفير الحاجات الأساسية التي تؤمن له حياته كإنسان، و التي عجز المجتمع المصري عن تلبيتها، نظراً لما يمر بها من ظروف خارجة عن الإرادة، الأمر الذي فرض على الجامعة دوراً لا يمكن إغفاله، أولها بل وأهمها نشر الوعي بين طلابها بالأوضاع الاقتصادية الحالية، وتوعية الطلاب بأن تلك الأوضاع المتدنية تعتبر وضعاً طبيعياً في سياق التغير الذي يجابهه المجتمع على كافة الأصعدة، بالإضافة إلى تحديد الأدوار التي على طالب اليوم بالجامعة القيام بها في سبيل مساعدة المجتمع المصري 
د. ولاء السيد عبد الله السيد صقر د. يحيى مصطفى كمال الدين

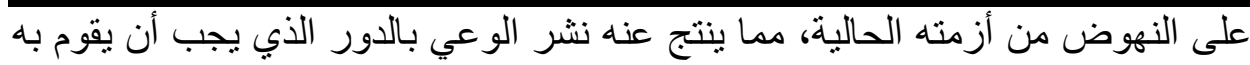
الجميع -كل في مكانه- من أجل المساهمة بفاعلية في إعادة بناء المجتمع المصري.('I') ولعل التغيرات الحادثة ليست ببعيدة عن إعادة تشكيل النسيج الاجتماعي للمجتمع المصري، فلا يمكن إنكار تغير النسق القيمي والأخلافي للمجتمع المصري، الأمر الذي يفرض على الجامعة مزيد من الاهتمام بدورها التربوي، دون التركيز على الدور التعليمي فحسب، فدور الجامعة في تنمية قيمة الانتماء للوطن الأم، لا يمكن تجاهله، بل تكريس كافة الجهود و الموارد المتاحة بالجامعة من أجل تعزيزه، وخاصةً في ظل انهيار نسق القيم الذي كان سائداً من قبل، واهنزاز صورة القدوة، وتغير النظرة للسلطة الأبوية التي حكمت المجتمع المصري لفترة من الزمن ليست بالبسيطة، الأمر الذي ثرتب عليه ضرورة التركيز على عدد من القيم والمرتكزات الثقافية التي تدعم الثخصية القومية المصرية، وتجعلها لا تز ال تمتلك المكونات و المقومات الأساسية التي تجعل لها شكلها المميز أمام المجتمعات المحيطة، وإلا تعرضت للاندثار والاختفاء في مقابل ثقافات وشخصيات أخرى، يخشى على المجتمع المصري من ضعف قدرته على الوقوف في مواجنتها.(1Ir)

القسم الثالث: الواقع الراهن لوسائط الجامعات الفرنسية واليابانية في تنمية الهوية والوطنية والقوى والعوامل الثقافية المؤثرة عليها.

قدّم الباحثان في هذا القسم در اسة وصفية تحليليـة لو اقع وسـائط جامعـات كل مـن

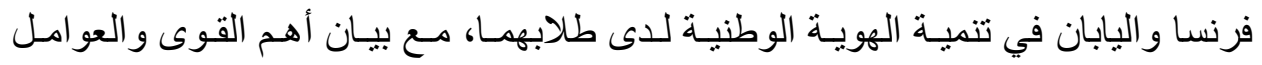
الثقافية المؤثرة عليها، وذلك حتى يتسنى الوقوف على أبرز الجهود و الممارسـات التي

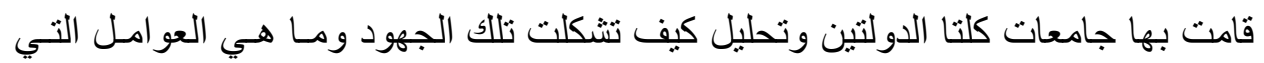
أدت إلى نجاحها. 
أثر برنامج إثرائي قائم على معايير العلوم اللجيل القادم (NGSS) في تنمية مهارات القرن الحادي والعشرين

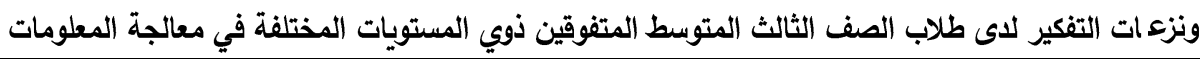

\section{الجامعات الفرنسية}

أكدت المؤسسـات التربويـة الفرنسية على دور التعليم في دعـم الهويـة الثقافيـة الفرنسية، وترجمت ذلك في أمـرين أساسيين وجب الانتبـاه إليهمـا داخل نظـام التعليم

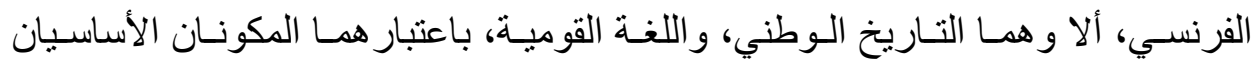
للهوية الوطنية الفرنسية، و السبيل لتدعيم قيم الانتماء للوطن الأم.(r')

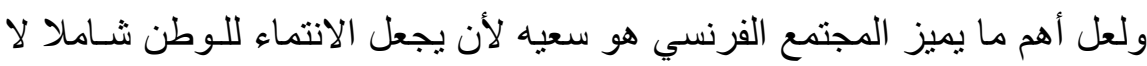
يقتصر على مستوى السكان الفرنسيين الأصـل فحسب، و إنمـا يعمل على غرس هذا الانتماء في نفوس المهاجرين من غير الفرنسيين القـاطنين بـه، مؤكدين على أن يتحـول

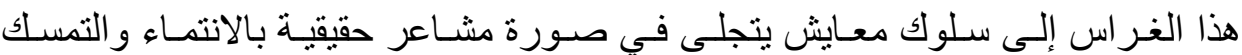
بالمكونات الأساسية للمجتمع، إذ تعدل الدولـة بمؤسســاتها على أن يكون هذا الانتمـاء

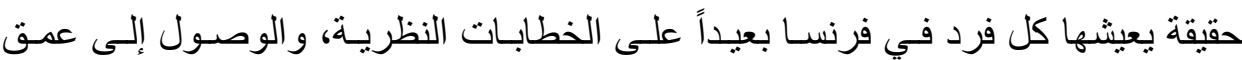
مكنون أفراد المجتمع، وتجـاوز ذللك إلى مشـاعر هم و التمكن مـن التعديل فيها، بحيث ينعكس ذلك في تصرفاتهم، بما يوضح مقدار اقتناعهم بالثقافة الفرنسية و أهميـة الانـدماج فيها، و الايمان بهويتها الوطنية، ويحقق الانتماء المنشود.(؛ (1) أولاً: نبذة مختصرة عن الواقع الراهن للجامعات الفرنسية: يُقِّم التعليم العـالي الفرنسـي بعدة مؤسسـات هي: الجامعـات، و الكليـات المهنيـة،

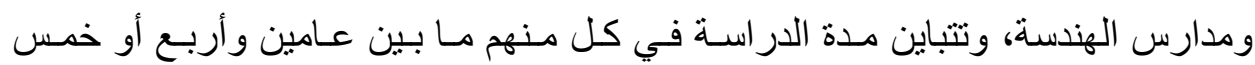
سـنوات، يحصـل بعـدها الخريجـون على أنمـاط متنو عـة مـن الثـهادات وفقـاً لطبيعـة المؤسسة التي التحقو ا بهـا، فيحصلون على درجـة الليسـانس، أو البكـالوريوس، تمهيداً لالتحاقهم بسوق العمل، أو إكمال دراستهم العليا تمهيداً لحصولهم على درجـة الماجستير

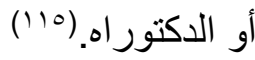


د. ولاء السيد عبد الله السيد صقر د. يحيى مصطفى كمال الدين

ويلتحق بمؤسسات التعليم العالي الفرنسية نسبة عالية من خريجي المرحلة الثانويـة

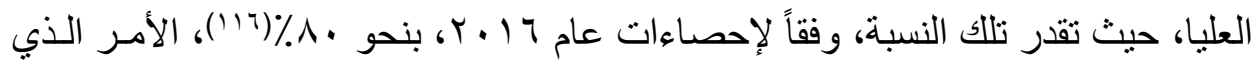
يؤكد على العدد الضخم الي يتلقى المعـارف، و الأفكار ، و العـادات، والقيم التي يرغب المجتمع الفرنسي في صبخ الطلاب بها، و هم على اعتاب الحياة العمليـة، إذ تعد الجامعـة بهذا الثكل هي المحطة و الفرصة النهائية التي تتيح للسـلطات التربويـة الفرنسية، صـبغ التئ الطلاب بالسمات النهائية التي تتيح لهم المشاركة الفعالة بالمجتمع الفرنسي. ويتميز التعليم العالي بفرنسا بالعدل و المساواة في تقديم الفرص التعليمية للملتحقين

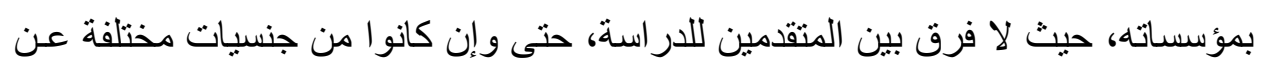

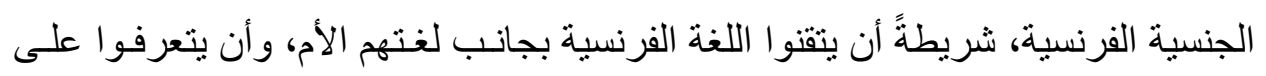

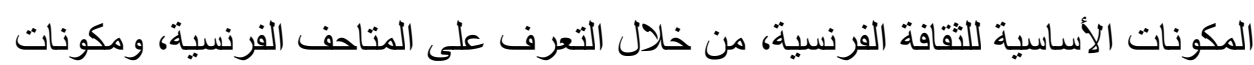
التراث الثقافي الفرنسي، بما بتيح للارسين الانـماج في التقافة الفرنسية التأقلم معها، وخاصةً إن كانو ا من غير الفرنسيين.(IVv)

وبرؤية تحليليـة يمكن القول إن السـلطات التربويـة الفرنسية، تهتم بمـا يقدم في

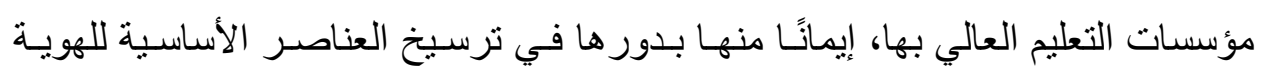

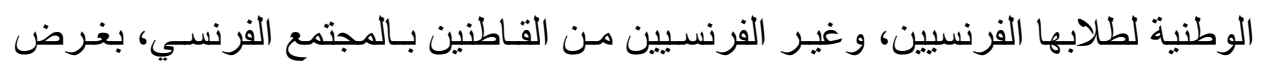
دمجهم، وضمان انتمائهم للمجتمع الذي يعيشون فيه، ولو لفترة مؤقتة، بما يُسهم في جعل

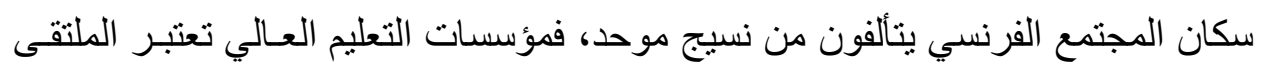
الأكثر شيو عاً الذي يجمع بين الدارسين الفرنسيين، وغير الفرنسين، الذين قرروا إكمـال

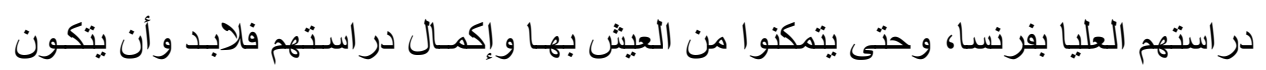

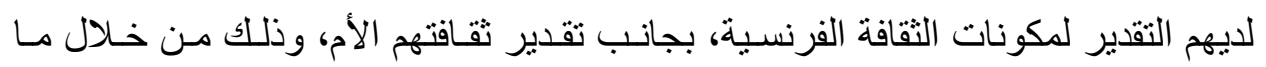
تُقدمه الجامعة لهم من برامج تتعكس آثار ها أيضا على الدارسين من الفرنسيين الأصليين

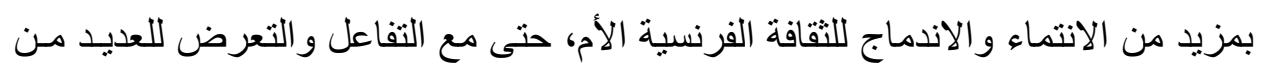

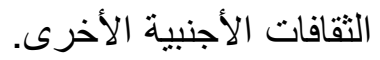

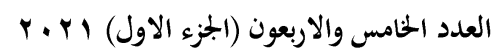

(377)
مجلة كلية التربية- جامعة عين شمس 
أثر برنامج إثرائي قائم على معايير العلوم اللجيل القادم (NGSS) في تنمية مهارات القرن الحادي والعشرين

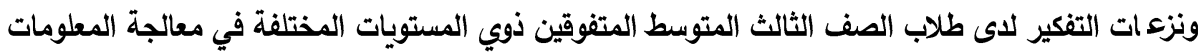
ثانياً: وسائط الجامعات الفرنسية في تنمية الهوية الوطنية لاى طلابها: عملت فرنسـا على تحقيق الانتمـاء المنشـود للمجتمع الفرنسـي عبر سلسـلة مـن السياسات والإجر اءات والوسائط التـي يمكن توضـيح بعضـاً منهـا على مستوى التعليم

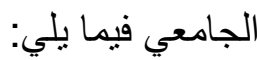

\section{1. تعزيز تعلم اللغة القومية والتعلم بها.}

تهنم السلطات التربوية الفرنسية، في كافة المراحل الدراسية، وكذا في الجامعـات، باللغة الفرنسية الأم، باعتبار ها أحد مكونات الهوية الوطنية، فهي لغة التدريس الأولى في

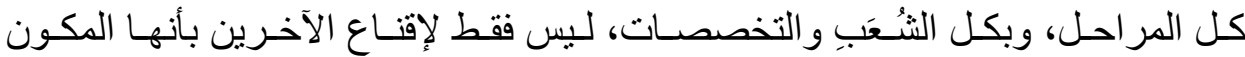
الأساسي للثقافة الفرنسية، والمعبر الأساسـي للهويـة الفرنسية، بـل لاهتمـامهم بـأن نشـر اللغة الفرنسية يعد الإعلان المناسب عن الهوية الفرنسية بين دول العالم كافة، الأمر الذي

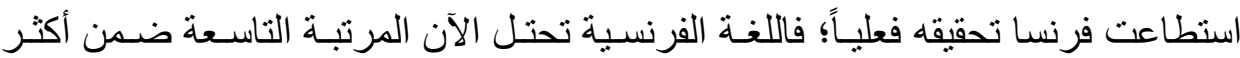
اللغات شهرة و انتشار اً بين سكان العـالم كافـة، ويتحدث بها مـا يقرب مـن اس ا مليون شخص على مستوى العالم، وليس فقط على الأراضي الفرنسية.(1') و على الرغم من هذا الانتشار للغة الفرنسية خارج أر اضيها، إلا أنه في إحدى قمم اللدول الناطقـة بالفرنسية التي شـهـها الرئيس الفرنسـي السـابق فر انسـوا ميتـران، دعـا الحاضرين إلى مساعدة فرنسا على الدفاع عن لغتها و هويتها في مواجهة الغزو الفكري الأمريكي.(19') و هو ما يوضح مدى اهتمام الدولة الفرنسية بلغتها.

ويفسر تأكيد الدولة الفرنسية على أهمية تعلم اللغة الأم والتعلم بهـا مـا نـص عليهـ

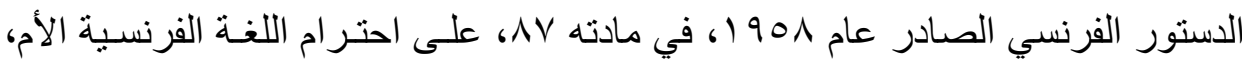
باعتبار ها اللغة الرسمية للبلاد، و أنها السبيل لتحقيق التقدم، و الانـدماج، و التماسـك بـين السكان، وبين المقاطعات الفرنسية المختلفة.(r') وهو تأكيد يكمن ور اءه الاهتمـام بدعم 
د. ولاء السيد عبد الله السيد صقر د. يحيى مصطفى كمال الدين

الهوية الوطنية الفرنسية، واعتبار هذا القضية مسألة مصبيرية، وجب ولب على نظسام التعليم بأكمله التعامل معها ـ لبس فقط على مستوى التعليم الجـامعي - و إحداث التكامل بـين مر احله المختلفة لتحقيق الأهداف المنشودة منها. وبالنظر إلى وظيفة اللغة الفرنسية كمـا نص عليهـا الدستور، تتضـح أهميـة تلك الك اللغة، ودور ها في الحفاظ على الأمن القومي للبلاد، فهي ليست وسيلة للتو اصـل فحسب، إنما هي وسيلة للتماسك، و عنوان للأمة الفرنسية، و الوسيلة التـي تميز المجتمـع الفرنسي وني عن غيره مـن المجتمعات، وبتعليمهـا للجنسـيات الجديدة القاطنـة بفرنسـا، تعتبر وسيلة للاندماج بين الأمم المتباينة، ووسيلتهم للتعرف على تفاصيل المجتمع الفرنسي، واحتـرام ثقافته و الاعتز از بها.

ولا يُعد اهتمام الدولة بتعليم لغات أخرى غير اللغة الفرنسية تناقضاً مـع مـاســته

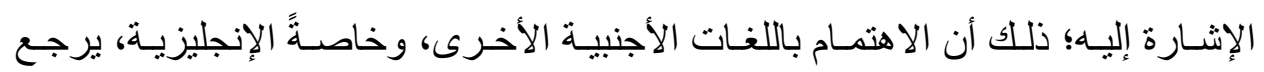

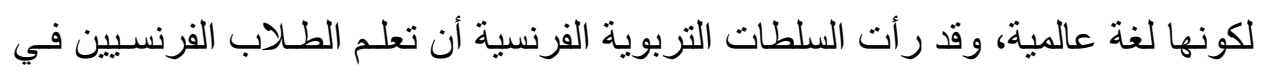

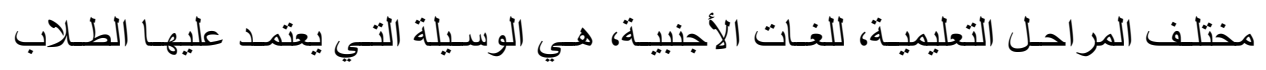
الفرنسيين للإعلان عن ثقافاتهم الفرنسية أمام العالم.(Ir) كما تهتم فرنسا بتعلم اللغات الأجنبية من أجل إحداث التو اصل و الانـدماج و التفـاهم بين سكان العالم على اختلاف ثقافـاتهم، فتجعل أمـر اسـتخدام اللغـات الأجنبيـة للعلاقـات الدبلوماسية، والسياحة، و التجارة، و غير ها من أمور الحيـاة العامـة، والتي تحرص على لـى

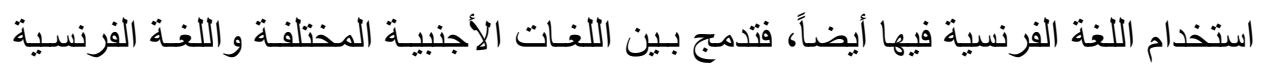
الأم، اقتناعاً منها بأن اللغة الفرنسية لا يمكن التخلي عنها، في مقابل لغـات أخرى، حتى لهى

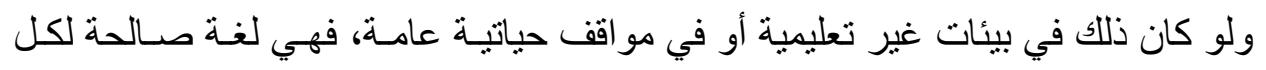

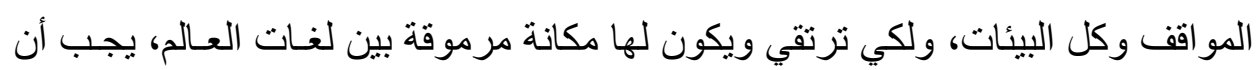

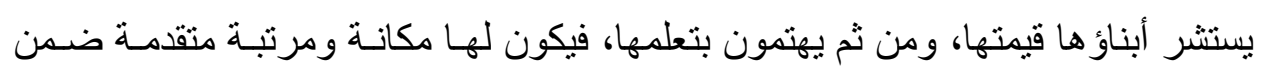

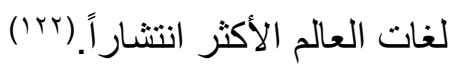

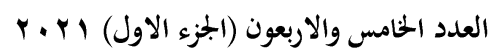

(379)
مجلة كلية التربية- جامعة عين شمس 
أثر برنامج إثرائي قائم على معايير العلوم للجيل القادم (NGSS) في تنمية مهارات القرن الحادي والعشرين

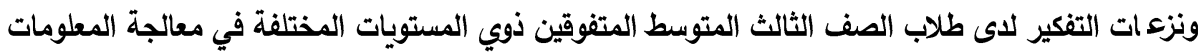

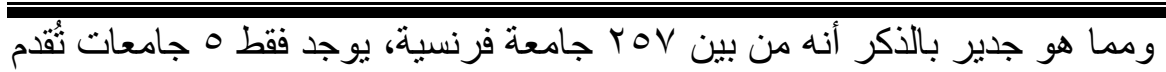
بر امجها بلغة غير الفرنسية وهي اللغة الإنجليزية. ولقد وضعت الحكومة الفرنسية شروطاً لقبول التحساق الطـلاب الأجانب الر اغبين في استكمال در استهم الجامعية بإحدى الجامعـات الفرنسية، وبـادرت بإعلانهـا للطـلاب الر اغبين في استكمال در استهم الجامعية، أو مرحلـة الدراسـات العليـا بإحدى الجامعـات

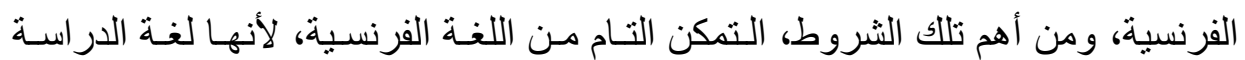
الأساسية، وللتأكد من ذلك، يخضع الطـلاب الأجانب لاختبـار متخصص لقيـاس درجـة تمكنهم من استخدام اللغـة الفرنسية، يُعقد تحـت إثــراف وزارة التعليم الفرنسية، وهـو اختبار يعادل اختبار TOEFEL، لقياس طلاقة الطالب في استخدام اللغة الفرنسية، قبل

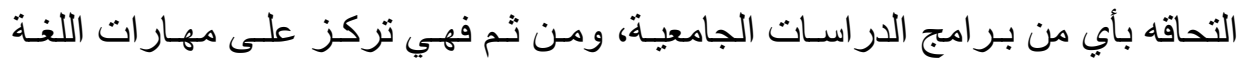
الأساسية كالقر اءة والكتابة والتحدث، والاستماع، لضمان عدم تعثر الطالب بالدر اسـة، أثناء العام الدراسي، إذا كان مستواه في استخدام اللغة غير مرضي.(123 )

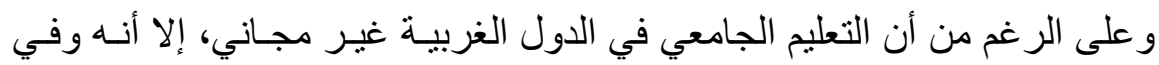
سبيل تعزيز تعلم اللغة الفرنسية والتعلم بها و الوقوف على ثقافة المجتمع الفرنسي، تقوم Open جامعة ييـل Yale University الأمريكيـة بتقديم مقررات در اسية مجانيـة Yale Courses ، لطلابها من مختلف التخصصـات، يُحاضـر فيهـا أسـاتذة فرنسيون، تلخخل رسـياً في مكونـات التقيـم النهائي للطـلاب، بعنـوان الأمـة، و الفلاحين، و اللغــة، و الهويـة الفرنسية A Nation, Peasants, Language, and French Identity أن اللهجات المنبنقة عن اللغـة الفرنسية، والتي يستخدمها الفلاحين الفرنسيين القاطنين بالأماكن الريفية الفرنسية، تعد إحدى المكونات الأساسية للغـة الفرنسية، والتـي لا يمكن

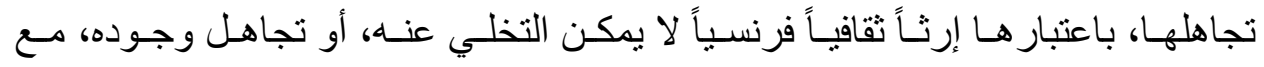

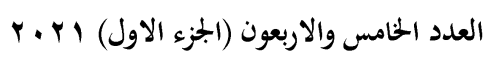


د. ولاء السبد عبد الله السبد صقر د. يحيى مصطفى كمال الدين

التحضر و المدنية التي تحتل المجتمعات في الآونة الأخيرة، وتضمنت المحاضرة الأفكار

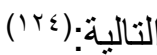
- - نشأة الهوية القومية الفرنسية، و العو امل المساهمة في التحديث بالمجتمع الفرنسي - اللهجات و اللغات المختلفة بالأقاليم الفرنسية. - هود التحديث بالمجتمع الفرنسي كالنقل، و المو اصلات، وخطوط السكلك الحديديـة، وتكوين وتعزيز الهوية القومية. - و اجبات معلمي المدارس، و أعضـاء هيئة التدريس بالجامعـات و الو الدين بالأسـرة من أجل دعم الهوية القومية الفرنسية لدى الأبناء.

- المدارس الفرنسية جهود دعم الهوية القومية لدى الطلاب في الآونة الأخيرة. وبالنظر لما سبق، و على الرغم من أن جامعة ييل إحدى جامعـات الو لايـات المتحدة الأمريكية، إلا أن حرص المجتمع الفرنسي وأساتنته الجامعيين دفعهم إلى تقديم مقررات مجانية للطلاب للتعريف بالهوية الثقافية الفرنسية، ، كما يتضح أن تقديم الجامعة لمثل هذا

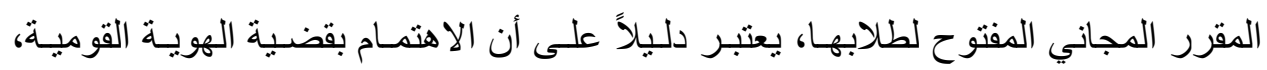

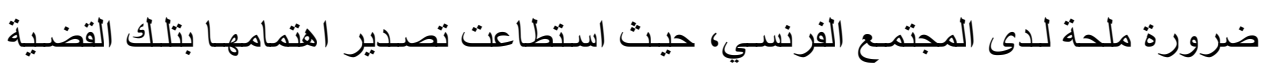

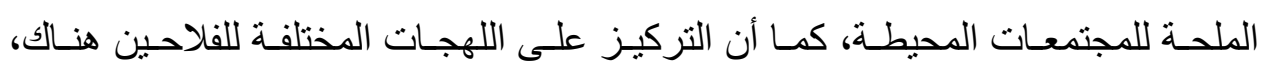

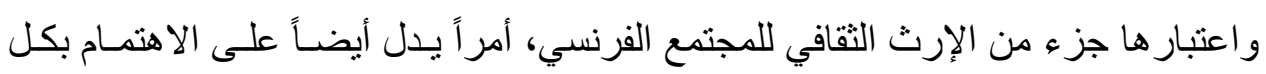

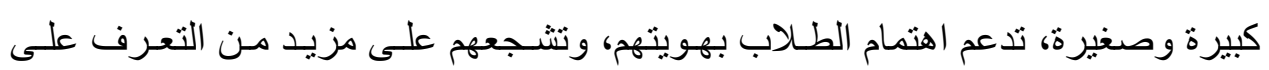

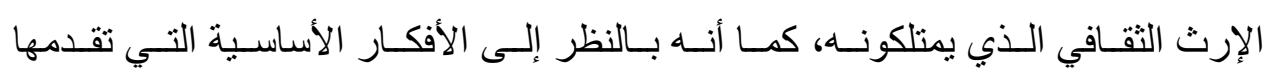

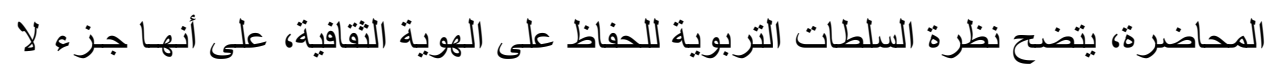

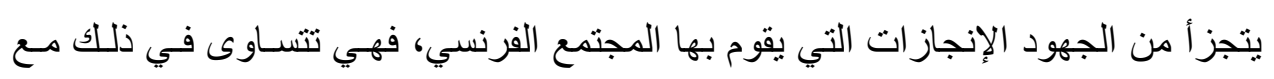
الإنجاز ات العينية التي يقدمها قطاع النقل و المو اصلات مثلا، و لا تقل عنه في الأهمية. 
أثر برنامج إثرائي قائم على معايير العلوم اللجيل القادم (NGSS) في تنمية مهارات القرن الحادي والعشرين

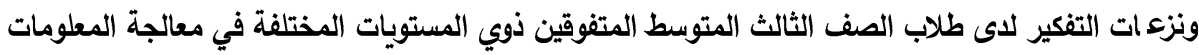

ومما سبق يتضح اهتمام الحكومة الفرنسية بتعزيز تعلم اللغة الفرنسية والتعليم بها من خلال:

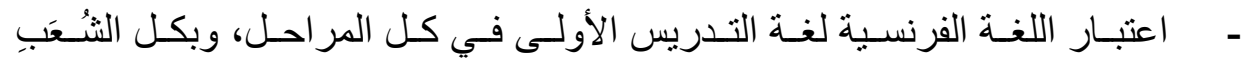

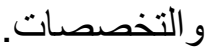

- - تأكيد لدستور الفرنسي على احتر ام اللغـة الفرنسية الأم، باعتبار هـا اللغـة الرسـية

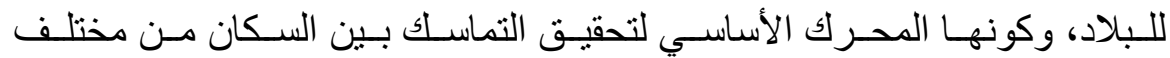
المقاطعات الفرنسية. - اهتمام فرنسا بتعلم اللغات الأجنبية لأجل التواصل وتحقيق الاندماج و التفـاهم ببين سكان العالم، واعتبار تعلم اللغات الأجنبية إحدى الوسائل التي يعتمد عليها الطـلاب الفرنسيين للإعلان عن ثقافاتهم الفرنسية أمام العالم - - مأكيدها على ضرورة اتقـان المتقدمين للار اسـة بـأي مـن جامعاتهـا للغـة الفرنسية سواء أكان ذلك على مستوى التعليم العالي أو مستوى الدراسات العليا r. المقررات الدراسية

تحـرص الجامعـات الفرنسية بـاختلاف تخصصـاتها على أن تنــي لـدى طلبتهـا المبـادئ الأساسية للمو اطنـة بهدف مســاعدتهم على الانتمـاء و الانـدماج داخـل المجتهـع الفرنسي، ومن ثم يـدرس الطـلاب مفـاهيم حقوق الإنسـان، والمواطنـة، و المبـادئ و القيم الداعمة للديمقر اطية و الايمان بالدولة ومؤسساتها، مـن خـلال تقديم معسارف واسعة عن

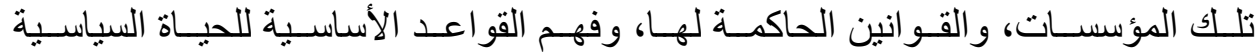
والاجتماعية بـالمجتمع الفرنسي، وهو الأمـر الذي يعطي للطـلاب الفرنسيين الفرصـة لمعرفة حقوقهم وواجباتهم وممارستها و الاضطلاع بها، وينمي لديهم مهار ات فهم الدور الفعال الذي يمكن أن يلعبوه على كافـة المسـتويات المحليـة، والقوميـة، و العالميـة، الأمـر الذي يدعم قيامهم بدور هم المستقبلي كمو اطنين مسئولين.(ro( ) 
د. و ولاء السيد عبد الله السيد صقر د. يحيى مصطفى كمال الدين

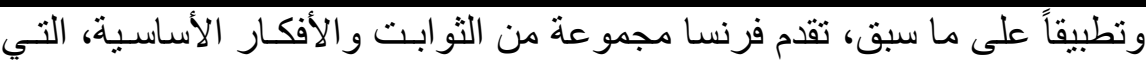
تتبناها الجامعات، ومن ثم الكليات بمختلف تخصصـاتها مـن أجل بنـاء عقليـات الطـلاب وتوجيهها نحو دعم فكر الاهتمـام بالهويـة القوميـة الفرنسية، والاهتمـام بـدعم الثخصية القومية الفرنسية، إذ يقع على عاتق كل جامعة أن نترجم تلك الأفكار و الثوابت، في شكل بر امج تتو افق وتخصص الكليات المختلفة، وتتلاءم ونو عية واحتياجات الطلاب المقيدين بها، ومن بين هذه الأفكار التي من شأنها تـدعيم الهويـة لـدى الطـلاب: الديمقر اطيـة، قيم المجتمع الفرنسي، مثل حقوق الانسان، و التأكيد على رفض العنصـرية، والتحيز، ودعم الحرية، و التضامن، و المساو اة.(זr)

وتطبيقاً لما سبق، تقدم كلية العلوم الإنسـية Faculty of Social Science، بجامعة مارسليا Marisela University، مجموعة من المقررات الدر اسية للدارسين بها، يدعم جزء كبير منها الهوية القومية، والانتماء للمجمع الفرنسي، يذكر منها في هذا

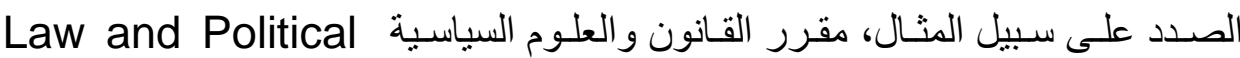
Science والانسانيات Lar).Language and Humanities

The Catholic Institute of كـا يقدم المعهد الكاثوليكي بمدينـة ليون Lyon عداً غير قليل من المقررات الجامعية التي تدعم الانتمــاء والهويـة القوميـة لـدى الطلاب الدارسين، منها مقررات حقوق الإنسان Human Rights، و العلاقات الدوليـة Importance of National International Relations

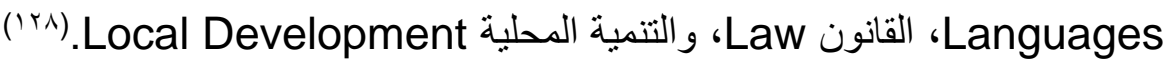
وتحرص كذلك جامعة باريس Paris University، و التي تعتبر إحدى فروع جامعة السوربون Sorbonne University، على أن تقدم للارسين بها في مختلف التخصصـات عدداً من الأفكار التي تدور في أساسها حول قضـايا تـدعيم الهويـة القوميـة، 
أثر برنامج إثرائي قائم على معايير العلوم اللجيل القادم (NGSS) في تنمية مهارات القرن الحادي والعشرين

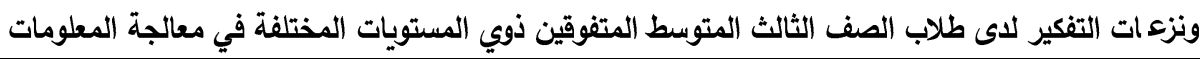

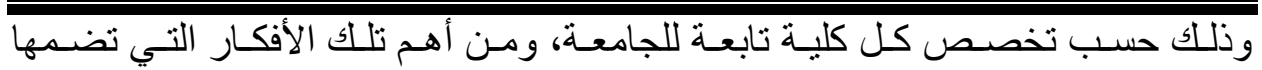
المقررات الدر اسية المقدمة بكليات الجامعـة القانون واللغـة Law and Language،

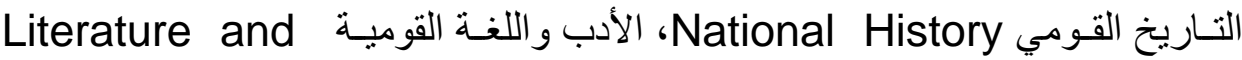
National Language ويتضح مما سبق عرضه، أنه على الرغم من اختلاف التخصصـات داخل الجامعـة

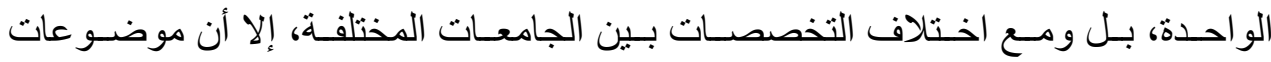
المقررات الدراسية التي تتضح من خلال عرض عناوينها أو الأفكار الأساسية التي تدور حولها، أنها تهنم بتدعيم قضية الهوية القومية الفرنسية، لدى الطلاب الفرنسيين، مـن خـلال مخاطبة عقلياتهم بأهم القضايا التي تجعلهم أعضاء فـاعلين بـالمجتمع الفرنسي، ومستعدين للاعمه و الاهتمام بقضاياه، والثعور بمزيد مـن الاهتمـام لحل مشـاكله، والثـعور بالانتمـاء تجاهه، خاصةً وهم على اعتاب المشاركة الفعلية فيه، بعد إنهاء در استهم الأكاديمية.

\section{r. - الأنثطة الطلابية الجامعية.}

The National Union of منـذ نشــأة الاتحـاد القومي لطـلاب الجامعـات

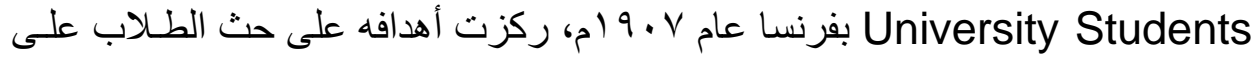
ممارسة أنشطة متنوعة تعزز اشتر اكهم بالحياة السياسية للمجتمع الفرنسي، وتجعلهم على وعي ودر اية بحقوقهم وو اجباتهم، لكي يقوموا بو اجبـاتهم ويعبرو ا عن حقوقهم بأسـوب طيب، كما ركزت أنشطة الاتحاد على تعريف الطـلاب بحكومتهم، ووظائفها الأساسية، ومكوناتهـا، ومـا الأدوار التـي يمكنهم القيـام بهـا لمســاعدة الحكومسة على أداء الأدوار المنوطة بها، وما هي الأحزاب السياسية السائدة بالمجتمع الفرنسي، مع العلـم أن السياسـة التي يسير بها الاتحاد القومي لطلاب الجامعات، يجب أن تسـاير السياسـة العامـة للاتحساد الأوروبس، ومسن ثم الاتحساد الأوروبـي للطسلاب European Students' Union، 
د. يحيى مصطقى كمال الدين د. د. ولاء السبا عبد الله السيا صقر

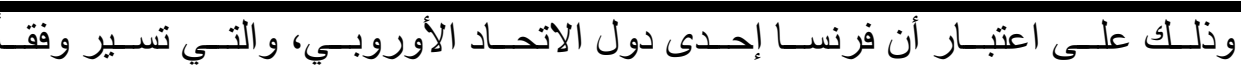

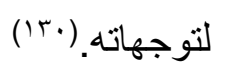

ومن أبرز تلأك التوجهات:(r)

- انفتاح طلاب الجامعات على الثقافات الأخرى، مع الحفاظ على المكونات الأساسية للثخصية القومية الفرنسية.

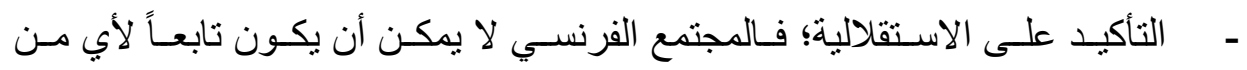

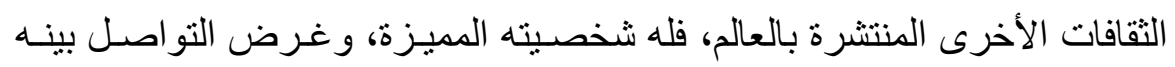
وبين المجتمعات الأخرى، هو الاستفادة وإحداث الثراء فقط لا غير.

- دعم الممارسات الديمقر اطية لاى الطلاب، وتعويدهم على الممارسات الديمقر اطيـة

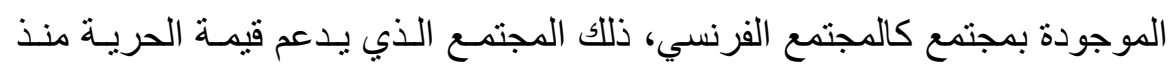

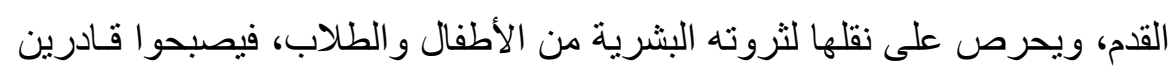
على الاشتر اك في الانتخابات، والتعبير عن الـرأي، والدفاع عن حقوقهم، والقيـام بواجباتهم، واختيار الممثلين المناسبين عنهم. كما يقوم اتحاد الطلاب بفرنسا بعدد من المشرو عات التي من شـأنها تـدعيم شـعور

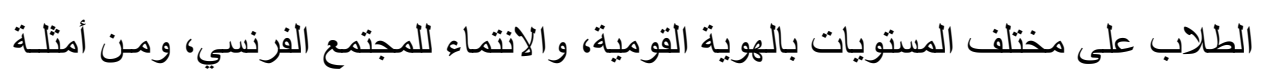

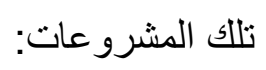

\section{Change Makers Academy مشروع أكاديمية صناع التغيير •}

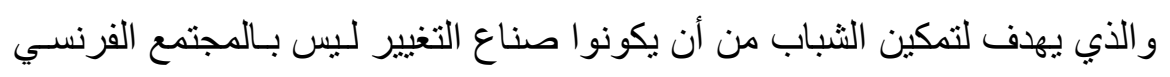
فحسب، و إنما بالمجتمع الأوروبي ككل، من خلال مشاركتهم الفاعلة في تطوير مجتمعهم

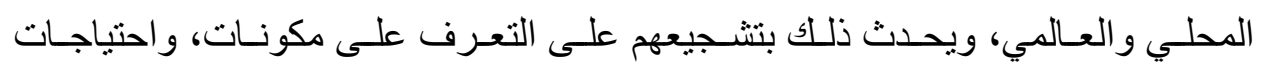

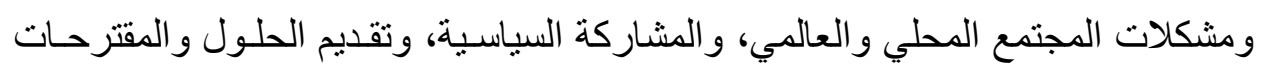

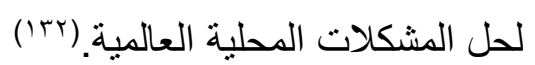

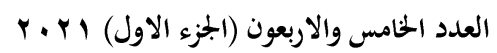

(385)
مجلة كلية التربية- جامعة عين شمس 
أثر برنامج إثرائي قائم على معايير العلوم اللجيل القادم (NGSS) في تنمية مهارات القرن الحادي والعشرين

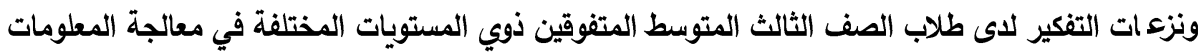

\section{Stronger Student Unions مشروع اتحاد الطلاب الأقوى}

و هو مشروع يهدف إلى دعم وتقويـة اتحساد الطـلاب عن طريـق عقد مزيـــــن

الثر اكات بين الاتحادات الطلابية على مستوى مختلف المر احل الدر اسية، فيجمـع طلابـا من المدارس بمختلف مر احلها، وكذا طـلاب مـن الجامعـات، ويؤدي هذا التو اصـل بين الطلاب إلى أن يصبحو ا أكثر قدرة على التعبير و ابداء الر أي و المقترحـات، وعلى حل المشكلات من خلال الاستفادة من خبرات بعضهم البعض.(r آ)

Sما أن هناك العديد من الأنشطة التي تقوم بها شبكة المعاهد الفرنسية Network of French Institutions تجاه الطلاب غير الفرنسيين مـن الر اغبين في استكمال در استهم الجامعية بمؤسسات التعليم العـالي الفرنسية، وذلك بغرض تعريفهم بـالمجتمع الفرنسي، ودعم انـماجهم بـه، بـل و الاعـلان عن الهويـة الثقافيـة الفرنسية، والثخصية القومية لهم، الأمر الذي ييسر اندماجهم داخله، ومن ثم تقدم تللك الثبكة للمهاجرين الجدد مـن الطـلاب عدداً مـن بـر امج الـدعم النفسي لمو اجهـة شـور هم بـالاغتر اب، بالإضـافة للدعوتهم لعـدد مـن ورش العمـل، و السـيمنار ات البحثيـة، والمؤتثر ات التـي تـدعم فكرة الاندماج بالمجتمع الفرنسي، بالإضافة الى تقديم بعض البر امج التي تمكن الدارسين مـن

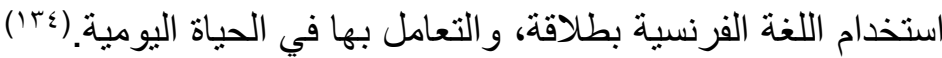

ومما سبق يمكن تلخيص أبرز الجهود التي تقوم بهـا الجامعـات الفرنسية لتعزيـز الهوية الوطنية لدى طلبة الجامعات فيما يلي:

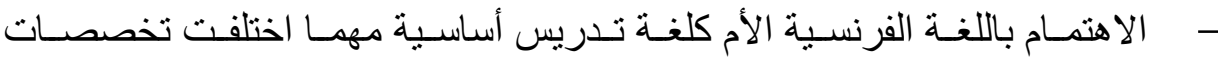
الطلاب الدارسين بها، وذلك دعماً للمكـون الأساسـي مـن مكونـات الهويـة الثقافيـة

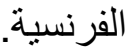


- الاهتمام بدر اسة اللغات الأجنبية بجانب التمكن من اللغة الفرنسية الأم، للفرنسيين و غير الفرنسيين والاهتمام بحث غير الفرنسيين على استخدام اللغـة الفرنسية في المو اقف التعليمية، مع الدمج بين اللغة الفرنسية ولغاتهم المختلفة، لإقتاعهم بأهميـة اللغة الفرنسية والتي لا تقل في قيمتها وأهميتها عن أهمية لغاتهم القومية.

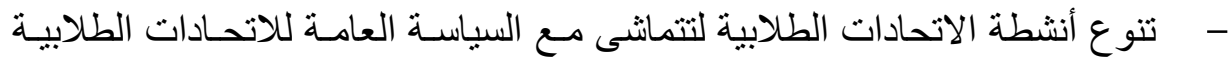
بدول الاتحاد الأوروبـي، والتـي تهتم في المقام الأول بإعداد المـواطن الفرنسي الذي يعرف حقوقه وو اجباته، ويستطيع أن يكون عنصر اً فاعلاً بالمجتمع لئع - اهتمام الأنشطة الطلابية بالتعرف على طبيعة وتفاصيل الحياة السياسية الفرنسية،

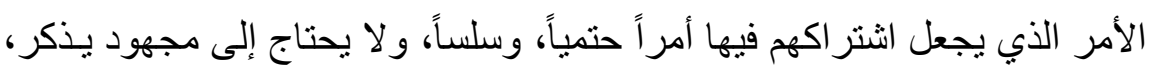
لتمكين الطلاب من الاندماج في العيش بإيجابية في مجتمع مثل المجتمع الفرنسي، و الذي يجعل شاغله الأكبر دعم قيم الحرية و الديمقر اطية.

- تنمية مشاعر الانتماء للمجتمع الفرنسي من خـلال المسـاو اة بين الفرنسيين و غيـر الفرنسيين من الجنسيات المهاجرة وذللك فيمـا يتم مـن ممارسـات تعليميـة وتثقيفيـة على مستوى الجامعة، وفيما يمارسه الطلاب من حقوق وواجبات، إذ أن بقاء قيمة الانتماء في نفوس الأفر اد لا يمكن أن تظل قائمة وتتمـو في نفس الوقت، إلا مـن خلال اقتناع تام بها، ومن خلال مشاعر حقيقية بالاندماج و الاقتر اب بين السكان وبين المجتمع الذي بسكنون فيه.

ثالثاً: القوى العوامل الثقافية المؤثرة على وسائط الجامعات الفرنسية في تنمية الهوية الوطنية لطلابها: ثمة عو امل مختلفة كان لها أثراً و اضحاً في الاهتمـام بتنميـة الهويـة الوطنيـة لدى أبناء المجتمع الفرنسي ومنهم طلبة الجامعات من خلال عدد من الوسائط التي استخدمتها الغالبية العظمى من الجامعات الفرنسية، فعلى المستوى التشريعي كان الدستور الفرنسي 
أثر برنامج إثرائي قائم على معايير العلوم للجيل القادم (NGSS) في تنمية مهارات القرن الحادي والعشرين

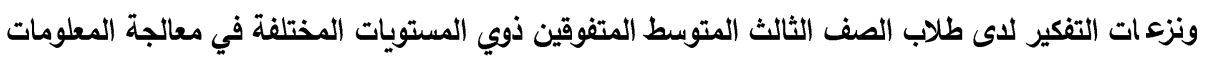

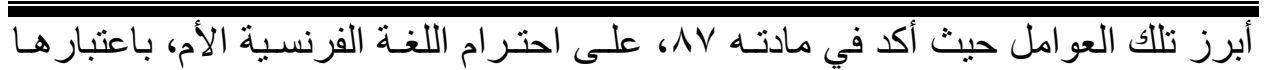
اللغة الرسمية للبلاد، باعتبـارهوسيلة لتحقيق التماسـك بـين المجتمع الفرنسـي الواحـ،

واعتبار هذا القضية مسألة مصيرية، وجب على نظام التعليم بأكمله الاهتمام بها.(ror) كما أكدت الاتحادات القومية لطلاب الجامعات على حث الطـلاب على ممارسـة الأنشطة التي تعزز اشتر اكهم بالحياة السياسية للمجتمع الفرنسي، لكي يقومـا بواجباتهم ويعبروا عن حقوقهم بأسلوب طيب.

و إذا نظرنا إلى العوامل الاجتماعية سـنجد أن التتوع الثقـافي للذين يعيشـون فوق الأر اضي الفرنسية، دفع الدولة إلى تأكيد الاهتمـام بالهويـة الوطنيـة تحقيقـا للتماسـك بـين لين أبناء المجتمع الفرنسي ترجع أصول الكثير منهم إلى الانجليز و الروس و البولنديين، كمـا

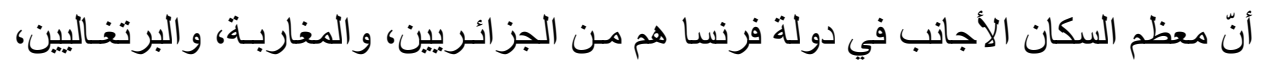
و الإيطاليين، و التونسيين، والإسبانيين، إلى جانب الاتر الك. (بri)

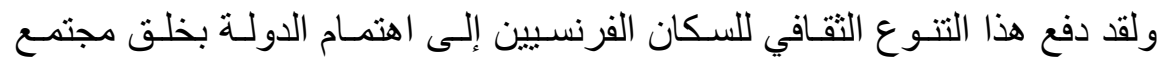
فرنسي واحد ذا ثقافة مشتركة تذوب بها كل الثقافات الأخرى وتتدمج تحت مظلة واحدة، بما يُحقق الانتماء للوطن الفرنسي، من خلال ما تمارسـهـ مـن ممارسـات ثقافيـة وتعليميـة و اقتصادية و اجتماعية. وتعكس العوامل التاريخية اهتمام فرنسا منذ القدم باللغة الفرنسية، حيث كـان ينظر

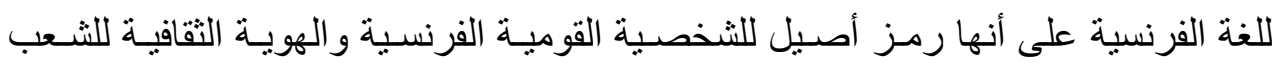
الفرنسي، إذ اعتبرت اللغـة الفرنسية إبـان القـرن الرابع عثـر هي اللغـة الأكثر انتشـار اً مقارنة بباقي لغـات الدول الأجنبيـة مثل الإسبانية و الإنجليزيـة والألمانيـة، وكـان الغالبيـة العظمى من سكان الدول الأوروبية آنذالك يتحدثون الفرنسية، الأمر الذي انعكس على قوة فرنسا السياسية والاقتصادية التي استمدتها من انتشار لغتها وكثرة مستخدميها(rYI)، ونتيجة لذللك اعتبرت فرنسا أن رمز القوة، والسيطرة يكمن في الحفاظ على مكانة اللغـة الفرنسية، 


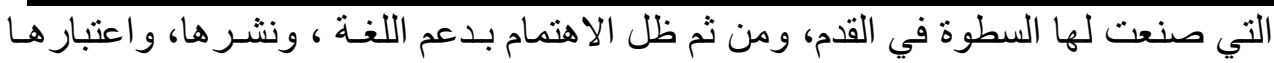
السبيل لاعم الهوية الفرنسية، والثخصية القومية الفرنسية وسط دول العالم أجمع. ومنذ اندلاع الثورة الفرنسية، التي نـادت بالحريـة و المسـاو اة، ظلت فرنسـا داعمـاً لتلك المبادئ، وحقها في أن تكون لها هويتها المستقلة، وحق كل الدول بالمثنل في ذات الأمـر، وصـرحت أن القـاطنين في فرنسـا مـن حقهم الحصـول على الجنسية الفرنسية و الانتماء للمجتمع الفرنسي، حتى و إن كان أباءهم أو أجدادهم من جنسيات مختلفة، الأهـر

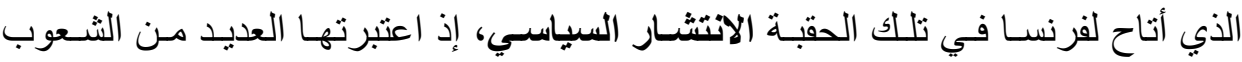

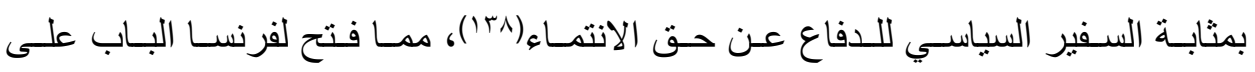

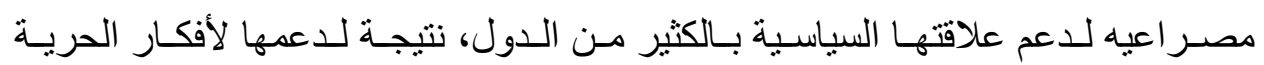
و المساو اة، و الاندماج، والانتماء، على الأر اضي الفرنسية، ونادت بذات الحقوق للقاطنين بالمجتمعات الأخرى.

وبالنظر لما سبق، يتضح أن ثمة عو امل متنوعة ساهمت في اهتمام فرنسـا بقضية

الهوية الوطنية، إذ اتضح ان جذور هذا الاهتمام، امتدت منذ القدم، واستمرت حتى وقتنـا الحالي، الأمر الذي انعكس على نظرة فرنسـا المستمرة لذاتها، على اعتبـار أنها كيـان مستقل، له شخصيته ومكانته، وسط المجتمع الدولي، والتي يجب الاستمر ار في الحفـاظ عليها حاضر اً ومستقبلاً، كما كانت الأمور قديماً.

\section{الجامعات اليابانية}

إن المتتبع للتاريخ القومي الياباني سيلاحظ أن الإمبراطورية اليابانية، والتي

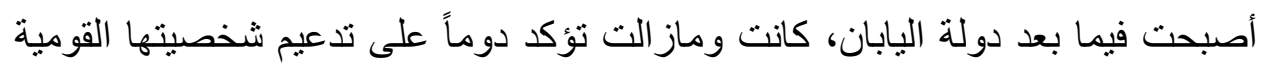
في مقابل القوميات العالمية الأخرى، إلا أن نظرتهم للأخر قد تبدلت وخاصة بعد بـاندان هزيمتهم في الحرب العالمية الثانية على يد الأمريكيين، وخروجهم من هذه الحرب العرب بأكبر كارثة إنسانية عرفتها البشرية، حيث حرص اليابانيون على تحقيق التوازن بين دعم الهوية الوطنية من جانب، وتحقيق الانتماء العالمي من جانب آخر، وذللك على خلاف

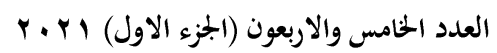

(389)
مجلة كلية التربية- جامعة عين شمس 
أثر برنامج إثرائي قائم على معايير العلوم اللجيل القادم (NGSS) في تنمية مهارات القرن الحادي والعشرين

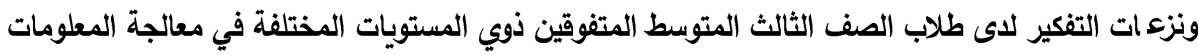

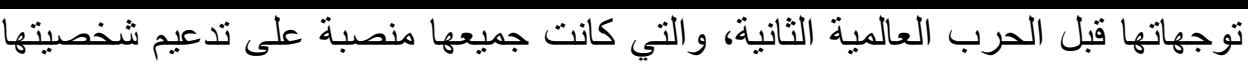

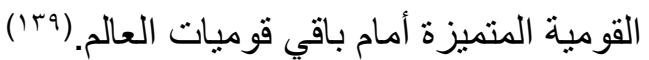
وفي سبيل حرص اليابان على شخصيتها القومية وهويتها الثقافية قامت بالعديد من الممارسات التي تُنمي الهوية الوطنية في نفوس أبنائها الطلاب، وذلك في المؤسسات التعليمية كافة، إذ يتم هذا الأمر بالمدارس والجامعات، بل ويتم الاهتمام به أيضاً على مستوى الممارسات الأسرية، نظر أ لأهميته في بناء الثخصية القومية اليابانية، ومكانتها وسط دول العالم.

\section{أولاً: نبذة مختصرة عن الواقع الراهن للجامعات اليابانية:}

يلتحق الطلاب اليابانيين بمؤسسات العليم العالي، بعد إتمام اثني عشر عاماً من الدراسة بالمدارس، حيث يدرسون لمدة ست سنوات بالمدرسة الابتدائية، وثلاث سنوات بالثانوية الدنيا، وثلاث سنوات آخرين بالمدرسة الثانوية العليا، ويمكنهم بعد إتمام دراستهم الجامعية، وفقاً للتخصص الذي يدرسونه، الالتحاق بعالم العمل، أو إكمال

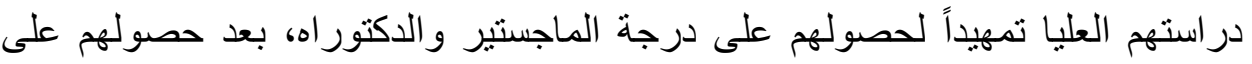
درجة البكالوريوس في الدرجة الجامعية الأولى.(•؛ (1) وتمتلك اليابان عددا ضخماً من الجامعات العامة والخاصة والوطنية، تضم عدداً

9. كبير ا من الطلاب في مختلف التخصصات، إذ يبلغ عدد الجامعات العامة حوالي

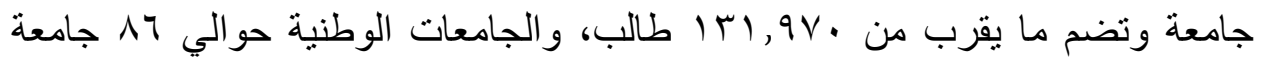

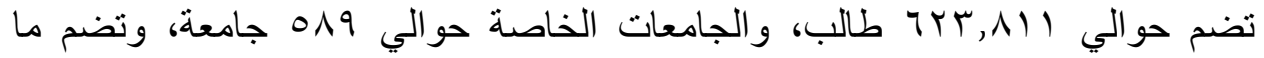

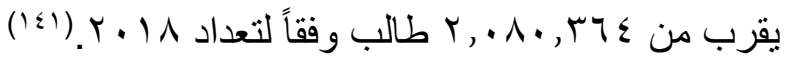
ومما سبق، يتضح ضخامة أعداد الطلاب الجامعيين اليابانيين، ومدى التأثير الذي يُمكن أن يُحدثه المحتوى الذي يُقدم لهم في تللك المرحلة، فهذا العدد الضخم من الدارسين، يعد فرصة لا بستهان بها، لدعم كافة القيم والمهارات اللازمة لصبغ الطلاب 
بها، و هم على أعتاب المجتمع العملي بعد إنهاء دراستهم الجامعية، ومن ثم تعتبر جهود دعم انتمائهم للتقافة اليابانية في تللك المرحلة، أمراً هاماً يجب أن يتم الاهتمام به، نظراً لكونه موجهاً لعدد ليس بالبسيط. وجدير بالذكر أن جهود دعم الهوية الوطنية للمجتمع الياباني تتم بذات الاهتمام في كافة المؤسسات سواء كانت جامعات عامة أو وطنية أو خاصة، إذ يدرس الطلاب الجامعيين - سواء من اليابانيين الأصليين أو من غير اليابانيين - في أب تخصص وبشكل إجباري مقررات اللغة اليابانية، واليابان والعالم المحيط، حيث تحرص الجامعات من خلال تللك المقررات على سبيل المثال لا الحصر، تمكين الطالب من اللغة اليابانية، و العلاقات الخارجية اليابانية، والثقافة اليابانية، ومقارنتها بالثقافات الأخرى، وتقدير قيمة

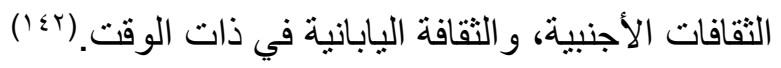
وبناء على ما سبق، يتضح أن بناء شخصيات الطلاب اليابانيين، لاعم الانتماء

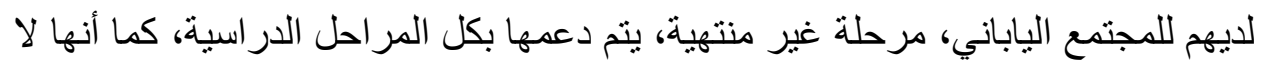
تقتصر على الطلاب اليابانيين فحسب، إنما يمتد الاهتمام أيضا لمختلف الجنسيات التي تدرس بالمؤسسات التعليمية اليابانية، وذلك بغرض تقدير المكونات الثقافية اليابانية، وكذا

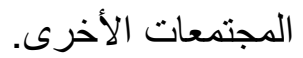

\section{ثانياً: وسائط الجامعات اليابانية في تنمية الهوية الوطنية لدى طلابها:} عملت اليابـان على تحقيق الانتمـاء المنشـود للمجتمع الفرنسـي عبر سلسـلة مـن

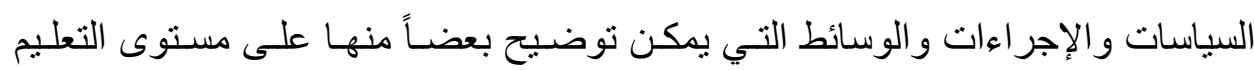

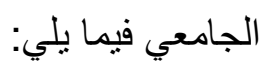

\section{1. تعزيز تعلم اللغة القومية والتعلم بها:}

حرصت الجامعات اليابانية على اختلاف تخصصاتها على تحقيق التوازن بين الاهتمام باللغة القومية من جانب، واكساب الطلبة مهارات التواصل بلغة العلوم الأولى لهى عالمياً وهي الإنجليزية من جانب آخر؛ وذلك من خلال جعل لغة التدريس الأولى 
أثر برنامج إثرائي قائم على معايير العلوم اللجيل القادم (NGSS) في تنمية مهارات القرن الحادي والعشرين ونزء ات التفكير لاى طلاب الصف الثالث المتوسط المتفوقين ذوي المستويات المختلفة في معالجة المعلومات

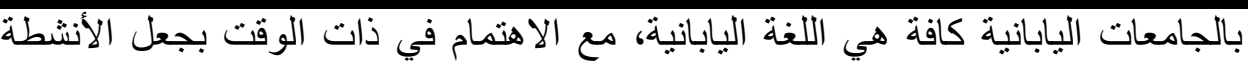
المصاحبة للمقررات الدراسية المقدمة للطلاب بالجامعة باللغة الإنجليزية، بالإضافة إلى تخصيص مقررات للطلاب الجامعيين لمساعدتهم على التمكن من اللغة الإنجليزية كلغة أجنبية تستخدم لتعميق قدرة اليابانيين على التفاعل مع العالم المحيط، وعلى الرغم من الاقتناع بأهمية اللغة الإنجليزية في إحداث التواصل بالعالم المحيط، وتحقيق الترابط بين المجتمعات المحيطة، والمجتمع الياباني، إلا أن هذا الأمر لم يثنى السلطات التربوية اليابانية عن استمرار الاهتمام بتدعيم تمكن اليابانيين من لغتهم الأم، حتى بالدراسة الجامعية، إذ أنها كانت لايهم ومن قديم الأزل هي المكون الأساسي المسئول عن دعم الهوية الوطنية، وتحقيق الانتماء للمجتمع الأم.(rء؛ (1) و على الرغم من الجهود السياسية التي تبذلها الحكومة اليابانية لتدريس اللغة الإنجليزية بمدارسها بما يمكنها من الاندماج الدولي، إلا أن الواقع المعاش على أرض له لهابله الواقع يشير إلى الرفض المجتمعي لأي توجه يؤثر في الهوية الوطنية للهجتمع الياباني. و هو ما أشار إليه نيشينو و واتاناب Nishino \& Watanabe (؛؛ () من أنه لا تزال هناك فجوة كبيرة بين السياسات الحكومية وواقع ممارسات تدريس اللغة الإنجليزية في

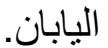

ويؤكد ما سبق أنه وعلى الرغم من قناعة اليابانيين بأن تعلم الطلاب للغة الإنجليزية سيُفيدهم في تحقيق تو اصلهم مع الأخرين ونقل ثقافتهم اليابانية إليهم، إلا أنه وطبقا للمورثات اليابانية التي يُشار إليها باسم Nihonjinron، فإن عدم القدرة على التحدث باللغة الإنجليزية يدل على اليابانية النقية، وأن اكتساب اللغة الإنجليزية هو دلالة على عدم نقاء يابانية الفرد. (1 (1) وتحقيقاً لتعلم اللغة اليابانية، تعتبر مدارس اللغات المنتشرة باليابان، هيئات تعليمية مخصصة لدعم تمكن الدارسين اليابانيين، أو غير اليابانيين الراغبين في استكمال 
د. ولاء السيد عبد الله السيد صقر د. يحيى مصطفى كمال الدين

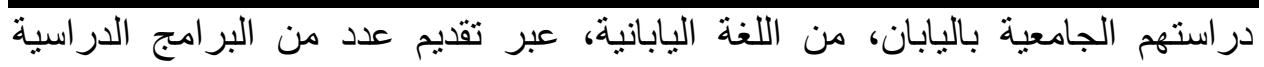
المتخصصة في مجال اللغة اليابانية للملتحقين بها، و التي تختلف في مدتها بحسب رغبة الطالب، ونوع الدراسة الأكاديمية الجامعية التي سيلتحق، و التي قد تكون برنامجاً تدريبياً لفترة قصيرة من الوقت، أو دراسة أكاديمية قصيرة المدى، أو دراسة أكاديمية جامعية طويلة المدى، وفي حال كانت اللغة اليابانية هي اللغة الأم للارس، فإنه سيكون بحاجة لاعم التمكن منها باستمر ار، من خلال التحاقه ببر امج متنوعة في صعوبتها، ومستوياتها

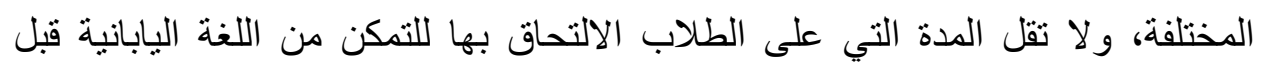

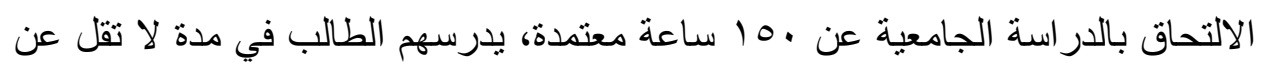
ثلاثة أثهر، بحيث تكون تلك المدة بمثابة البداية، التي على الطالب تتميتها من خلال الالتحاق بالمزيد من البرامج التي من شأنها دعم قدرته، وتمكنه من استخدام اللغة النة

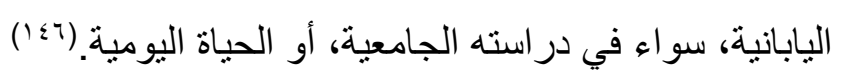

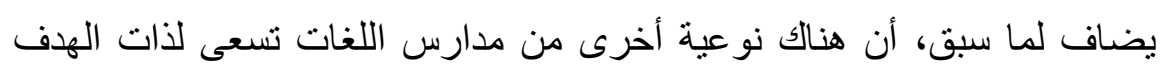

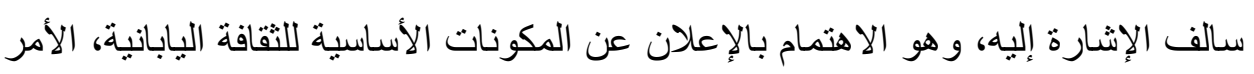
الذي يؤدي إلى مزيد من دعم الارتباط بين الدارسين الجدد بالجامعات اليابانية، والثقافة الإنة Genki Japanese and اليابانية، وتعتبر مدرسة جينكي للغة اليابانية والثقافة لإنة Culture School مثالاً حياً لهذا النمط، و الذي لا يهنم بتمكين الدارسين من استخدام اللغة اليابانية و التمكن منها فحسب، بل أيضاً يهتم بتعريفهم بالمكونات الأساسية للثقافة اليابانية لضمان مزيد من الاندماج، والثتعور بالتآلف مع المجتمع الياباني، وفي سبيلها لتحقيق ذلك، تنظم المدرسة للارسين رحلات ميدانية تحرص من خلالها على ادماج الدارسين في مواقف حياتية حقيقية مع اليابانيين في الثشارع، بحيث يمارسون مهارات

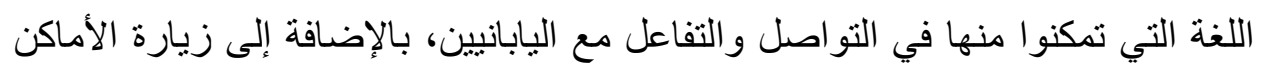

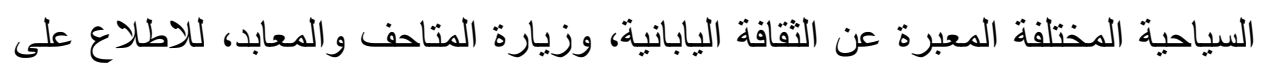
العادات والتقاليد، والاطلاع على الطراز المعماري الفريد لها، بالإضافة إلى القراءة عن

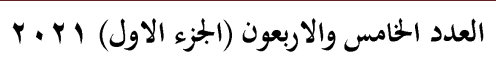


أثر برنامج إثرائي قائم على معايير العلوم اللجيل القادم (NGSS) في تنمية مهارات القرن الحادي والعشرين

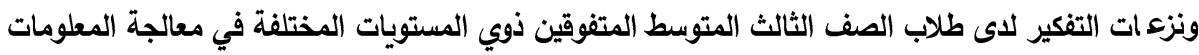

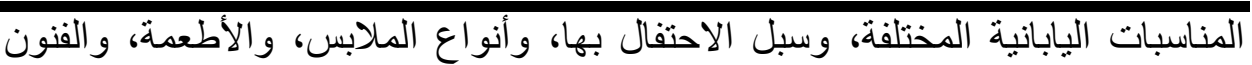
اليابانية، وأهم المنتجات اليدوية التي ينم انتاجها في المناسبات المختلفة، بل والمشاركة في انتاجها بأنفسهم بالتعاون مع اليابانيين. (147)

ومما سبق يتضح كيف حرصت الجامعات اليابانية على تعزيز تعلم اللغة اليابانية و التعلم بها من خلال تنظيم عدد من مدارس اللغات التي تكسب الطالب اللغة اليابانية ليتمكن من الالتحاق بالتعليم الجامعي الياباني الذي يقوم في معظمه على اللغة اليابانية باعتبار ها اللغة الأم للاولة، كما أن الجامعات تستثمر هذه المدارس في تعريف الدارسين بالثقافة اليابانية وتنظم لهم البرامج التدريبية لتحويل الدراسة إلى واقع يعيشونه يمارسون فيه اللغة ويطبقون فيه ما تعلموه من عادات وقيم.

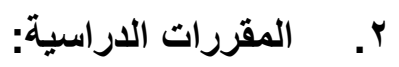

حرصت اليابان في جميع مراحل تعليمها على أن تؤصل للأخلاق والانتماء

الوطني، وتضمين ذلك في موضو عات معظم المقررات الدر اسية. (^؛ () تقدم اليابان عدد من الموضوعات الدراسية المدمجة داخل العديد من المقررات الدراسية بالجامعة على اختلاف تخصصاتها، حيث يُطلب إلى عضو هيئة التدريس أن مئ مئ ير اعي، مهما كان تخصصه، وجود تلك الموضوعات داخل المقرر الدراسي الذي يقدمه لطلابه، وعليه أن يوائم أفكار تللك الموضوعات مع طبيعة المقرر المقدم للطلاب بالجامعة، ومن تللك الموضو عات و القضايا ما يلي:(9 ؛ () Love the Country, Do it no أحب وطنك وافعل ذلك دون ضرر لأحد .Harm Serve the People, Never Betray اخدم الناس واياك ان تخدعهم them. 
Be Diligent, not Indolent. كن مجتهد ولا تكن كسلان Be United, Help اتحد مع الآخرين، ساعدهم، لا تصنع مكاسبك على حسابهم Each Other, Make no Gains at Other's Expense. Be Honest, Don't كن أمين ولا تضحي بالقيم من أجل أي مكاسب مادية Sacrifice Ethics for Profit. وبالنظر للقضايا السالفة، يتضح أنها في العموم، قضايا تدعم قيم الانتماء و الجماعية بين أبناء الثعب الياباني، ففكر الانتماء للمجتمع الياباني والترابط بين شعبه، هي الفكرة المسيطرة على القضايا التي يجب التعامل معها بالمقررات الجامعية المقدمة للطلاب، فالانتماء للمجتمع لا يتم عملياً إلا من خلال ممارسات تدعم الصالح العام لسكان هذا المجتمع، والتي تتضح في شكل التعامل مع بعضهم البعض، والعمل الفريقي من أجل الإنجاز، وتحقيق فكرة الاتحاد مع الآخرين، والأمانة في التعامل، فجميعها قضايا تحث على التعاون، والاتحاد، والإيجابية، والانتاج، والصالح العام، والقيم الإيجابية التي تقوم على أساس الأخلاقيات الفعالة التي تبنى عليها المجتمعات التي تستغل طاقاتها البشرية من أجل تحقيق الخير العام لجموع البشر القاطنين بها. ومن ناحية أخرى تقدم الغالبية العظمى من الجامعات اليابانية، عدداً متنوعاً من المقررات الدراسية المستقلة، كما سبقت الإشارة لبعض منها على سبيل المثال، والتي تركز على دعم الهوية الثقافية للطلاب الملتحقين بها، والتي من الممكن أن يختلف مسماها من كلية لأخرى داخل الجامعة، لكنها تهرف لتحقيق ذات الأهداف، ومثال ذلك، لكرئ تحتوي جامعة ياماناشي جاكيون Yamanashi Gakuin University، على عدد من الكليات في تخصصات متعددة مثل العلوم السياسية، والأعمال والاقتصاد، و الفنون، و الآداب، وفنون اللغة، وغيرها من العلوم، وبالرغم من اختلاف تنوع التخصصات المتاحة للطلاب للاختبار من بينها، إلا أن هناك بعض المجالات الثابتة، التي على الطلاب الملتحقين بالجامعة أيا كان تخصصهم دراستها، مثل مقرر الدراسات اليابانية 
أثر برنامج إثرائي قائم على معايير العلوم اللجيل القادم (NGSS) في تنمية مهارات القرن الحادي والعشرين

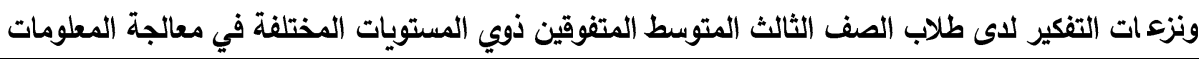
Japanese Studies، و الذي يركز في موضو عاته على التعامل مع مكونات الثقافة اليابانية كافة، والفنون اليابانية، والاحتفالات، والعادات والتقاليد، وطبيعة المجتمع الياباني، وأهم الأحداث في حياة المجتمع الياباني، وشكل الحياة السياسية باليابان، وسبل المشاركة الفعالة فيها، والفنون الثعبية اليابانية، والموسيقا، و المسرح الياباني، و أصل الضيافة اليابانية، وموضو عات من هذا القبيل.(10.) كما يدرس طلاب كلية التربية والدراسات الانسانية بجامعة اكيتا اليابانية ‘Faculty of Education and Human Studies- Akita University عدداً ليس بالقليل من المقررات التي من شأنها دعم ارتباطهح بالثقافة اليابانية الأم، ويتضح ذلك من خلال الاطلاع على المقررات الدراسية الإجبارية المقررة على الطلاب Compulsory Program for المعلمين المرشحين للعمل بالمدارس الابتدائية Elementary Teachers الدراسي مقررات: اللغة اليابانية الأم Japanese Mother Tounge، والفنون لإن والأعمال اليدوية Arts and Crafts، والدراسات الاجنماعية Social Studies، والموسيقا والفنون Music and Arts. (151). ويتضح من خلال الاطلاع على ما سبق، الجرعة المكثفة التي يحصل عليها الطالب المعلم، من المقررات التي ترتبط بالإرث الثقافي الياباني، وقد يرجع السبب في ذللك، إلى أن المعلم المرشح للعمل بتلك المرحلة الدراسية الهامة، تقع على عاتقه مسئولية ضخمة، فهو المسئول عن زراعة بذور الانتماء للثقافة اليابانية الأم في عقلية الأطفال، ممن سيقوم بالتدريس لهم بعد تخرجه من الجامعة، الأمر الذي يتطلب منه أن يكون في الأساس معلماً قوي الانتماء لهذه الثقافة، ليتمكن من زراعة بذور الانتماء القابلة للنمو في نفوس وعقول الصغار من طلابه، حيث يعتبر المعلم في هذه المرحلة هو المسئول عن توفير الأساس، الذي سوف يقوم عليه باقي البناء في المراحل الدراسية التالية لطلابه، 
د. ولاء السيد عبد الله السيد صقر د. يحيى مصطقى كمال الدين

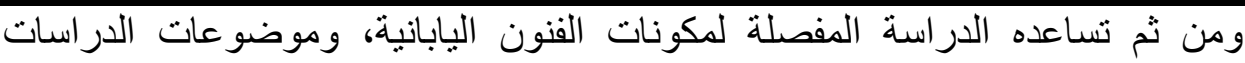
الاجتماعية التي تركز على مكونات المجتمع الياباني وتاريخه قضاياه، والفنون و الأعمال اليدوية المرتبطة بالثقافة اليابانية، وفنيات استخدام اللغة اليابانية من التمكن منها، لتمكين الدارسين الصغار منها، باعتبار أن كلها مجالات تساعد الطالب المعلم على مزيد من الانتماء للمجمع الياباني وتقدير الثقافة اليابانية الأم، مما يسهل عليه تمرير ذات الانتماء و التقدير لطلابه فيما بعد.

\section{r. الأنشطة الطلابية الجامعية.}

تحرص الجامعات اليابانية وفي إطار ما يقوم به الطلبة من أنثطة جامعية على تضمين الهوية الوطنية للمجتمع الياباني في تللك الأنشطة، وذلك من خلال تنظيم العديد من الفعاليات التي يكون غرضها الأساسي التعامل مع التراث الثقافي الياباني، و التعرض للهوية الوطنية اليابانية ودعمها، بل وعرض مكوناتها الأساسية أمام العالم، وفي إطار ذللك تقوم الغالبية العظمى من الجامعات اليابانية بعمل معرض ومتاحف سنوية لعرض أهم المنتجات التي يقوم الطلاب بتصميمها وانتاجها والتي تعبر في ذات الوقت عن المكونات الأساسية للثقافة القومية اليابانية، وتدعيم الهوية الوطنية لاى الطلبة أنفسهم، فهنالك متحف الكنوز الثقافية Museum of Cultural Treasures، و الذي يعرض فيه تماثيل خشبية وأخرى مصنوعة من الصلصسال لأهم المنتجات التي تمثل الثقافة اليابانية، والتي يقوم الطلاب بإنتاجها بأنفسهر وكتابة الملصقات التي تعبر عن الثقافة التي يمثلها كل منتج ثقافي قامو ا بإنتاجه، كما أن هناك أيضاً معرض البناء الياباني The Japanese Building Fair المعماري الياباني بطابعه المميز على مر العصور. (lor) ولا تقتصر الأنشطة الطلابية الجامعية على إنتاج منتجات عينية تمثل الثقافة اليابانية فحسب، و إنما تحرص الجامعات اليابانية، على تقديم طلابها أنفسهم كثخصبات مستقلة، لها مميز اتها، وشخصيتها المتفردة بين أقرانهم من الطلاب الجامعيين من جميع 
أثر برنامج إثرائي قائم على معايير العلوم اللجيل القادم (NGSS) في تنمية مهارات القرن الحادي والعشرين

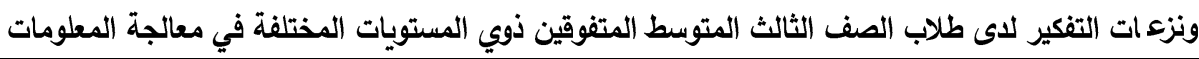

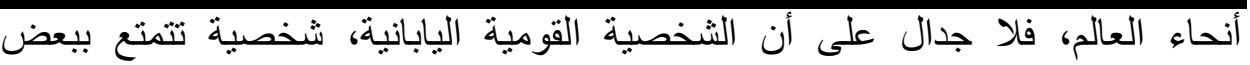
المميزات و السمات الأخلاقية، كمر اعاة شعور الآخرين، والتعاون، و الخدمة المجتمعية، والأعمال التطوعية، من ثم تهتم الجامعات اليابانية بدمج الطلاب في أنشطة من شأنها خدمة المجتمع الياباني، الأمر الذي يدل على الارثباط بالمجتمع الياباني، وتقديره، ومن Nursing أمثلة نلك الأنشطة نمكين الطلاب من اكتساب خبرة الرعاية التمريضية Care Experience فعلية لبعض المهارات التي تتصل بمجال التوعية الصحية، ومساعدة المرضى في المنزل أو المستشفيات، في مختلف المراحل العمرية، وملاحظة الأعراض التي يعاني منها البعض، ومن ثم المساهمة في الاكتشاف المبكر للمرض، وتوجيه المريض للمتخصص لمساعدته في الوقت المناسب، وتقديم الخدمات الصيدلانية لهم وقت الحاجة تطوعاً(10\%)، الأمر الذي يعكس الاهتمام بدمج طلاب الجامعات بالمجتمع الياباني، و الانخراط في خدمته، مما يزيد انتمائهم له، واندماجهم فيه، وتطوعهم لمساعدة المواطنين، والمشاركة الفعالة في إحدى قطاعاته الهامة، ألا وهو القطاع الصحي، ومن ناحية أخرى فهي أنتطة تعلن عن السمات المميزة للثخصية القومية اليابانية، التي تهنم بالتعاون، والتضامن، و العمل الفريقي، والخدمة المجتمعية، والتعاطف مع الآخرين، كبعض من السمات التي زرعها النظام الياباني في عقلية وممارسات الطلاب، ولاسيما الجامعيين منهم، وهم على أعتاب الحياة العملية. وفي إطار حرص الجامعات اليابانية على تعزيز الهوية الوطنية للطالب من جانب وربطه بالهوية العالمية من جانب آخر، تحرص الجامعات على دعوة أعضاء المجتمع الجامعي بشكل عام، والطلاب بشكل خاص، لحضور بعض الفاعليات التي تهدف إلى تعزيز الهوية الثقافية لهم، وتتمية قدرتهم على التعامل مع العالم المتنوع ثقافياً، من خلال حضور العديد من المؤتمرات، والندوات، التي تعقد في هذا الإطار، ويذكر هنا على 
د. ولاء السيد عبد الله السيد صقر

د. يحيى مصطفى كمال الدين

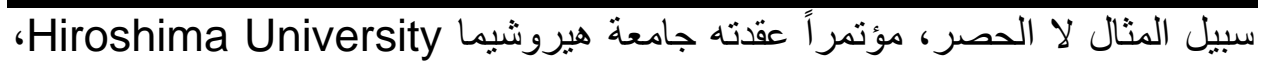
Multicultural بر تطبيق زووم Zoom، بعنوان التفاهم المتعدد نقافياً Understanding تحقيق التوازن المنشود بين ما هو عالمي، وما هو وطني، كما دعا المؤتمر لضرورة تعلم اللغات الأجنبية التي تمكن من التواصل والتعاون مع سكان العالم، وفي ذات الوقت

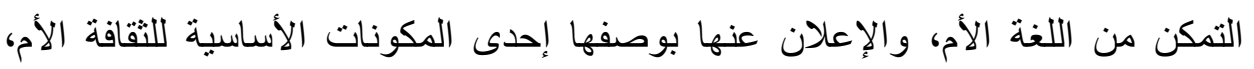

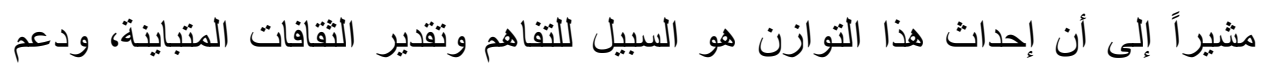

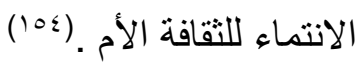

وبرؤية تحليلية لما يقوم به الطلبة من أنشطة جامعية تعزز الهوية الوطنية

للمجتمع الياباني، يمكن القول إن تللك الأنشطة تعمل على تدعيم انتماء الطلبة للثقافة

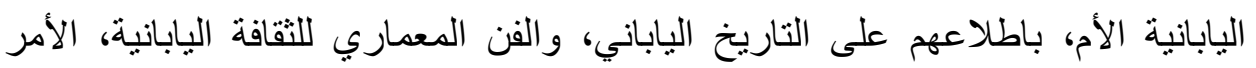
الذي يربطهم بتاريخهم الوطني، ويجعلهم أكثر التصاقا بأحد المكونات الأساسية للهوية ولهية

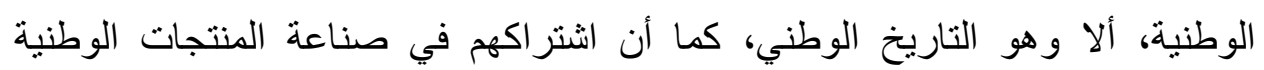

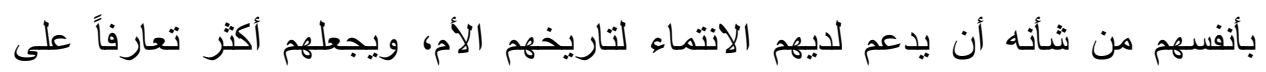
مكوناته، وأكثر قدرة على الإعلان عنه أمام الآخرين، بالثكل الذي يجعلهم سفراء بلادهم

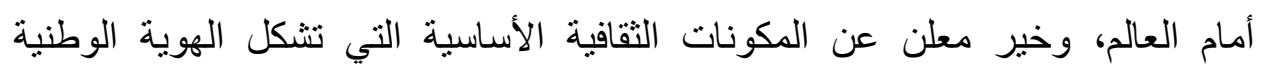
للمجتمع الياباني، وذللك انطلاقا من إيمانهم بأنه لا يكفي اقتناع اليابانيين أنفسهم بتفردهم

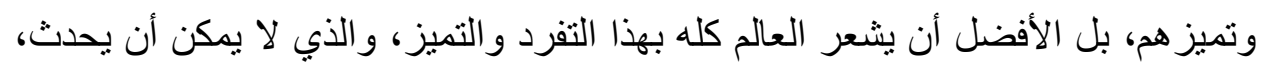
إلا من خلال السير في خطة متكاملة ومنظمة وعلى كل المستويات، يتم من خلالها الإعلان عن دلالات هذا التفرد والتميز أمام دول العالم كافة، لجعل العالم بأسره يقر الثقافة اليابانية ويستشعر تفردها مما يراه م ممارسات حقيقية يمارسها الثباب الياباني

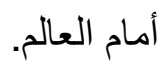


أثر برنامج إثرائي قائم على معايير العلوم اللجيل القادم (NGSS) في تنمية مهارات القرن الحادي والعشرين ونزء ات التفكير لاى طلاب الصف الثالث المتوسط المتفوقين ذوي المستويات المختلفة في معالجة المعلومات

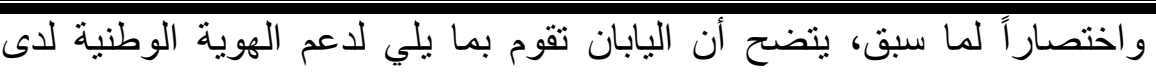

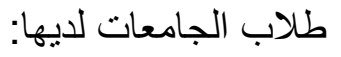

- - الاتمام بتدريس المقررات الدراسية الجامعية مهما اختلف تخصصها باللغة اليابانية الأم، وتعزيز تعلم الطلاب الأجانب لها من خلال مدارس اللغات. - - تقديم مجموعة من البرامج التي من شأنها تدعيم تعرف طلاب الجامعة اليابانيين باللغة الإنجليزية كلغة أجنبية لدعم التواصل بين شعوب العالم. - الاهتمام بممارسة الأنثطة المصاحبة للمقررات الدراسية الجامعية بالجامعات اليابانية باستخدام اللغة الإنجليزية. - اهتمام الجامعات اليابانية بعمل متاحف ومعارض تعبر عن مكونات الهوية الوطنية اليابانية، وتعرض تلك المكونات أمام العالم. - قيام الطلاب الجامعيين بأنفسهم بصناعة المكونات الأساسية لتلك المتاحف و المعارض ليتعارفوا بشكل أعمق على المكونات الأساسية لهويتهم الوطنية، ويكونون أكثر قدرة على الإعلان عنها أمام دول العالم كافة. - - تضمين العديد من القضايا التي تدعم الانتماء للهوية الوطنية للمجتمع الياباني بالمقررات الدراسية الجامعية - على اختلاف تخصصاتها- فتصبح المهمة الأساسية لكل عضو هيئة تدريس هي موائمة تخصصه الأكاديمي والمفردات الأساسية لكل قضية من القضايا التي عليه تبنيها و عرضها لطلابه، لدعم هويتهم هونيه الوطنية للمجتمع الياباني. - عقد ندوات ولقاءات ومؤتمر ات تعمل على تعزيز الهوية الوطنية للمجتمع الياباني من جانب وربطها بالهوية العالمية من جانب آخر، لتخريج طالب معتز هويته منتميا لمجتمعه العالمي وفاعل فيه. 
د. يحيى مصطفى كمال الدين د. ولاء السيد عبد الله السيد صقر ثُالثاً: القوى العوامل الثقافية المؤثرة على وسائط الجامعات اليابانية في تنمية الهوية الوطنية لطلابها: عند تحليل الواقع الحالي للمجتمع الياباني، يلاحظ أن هناك عدداً من القوى و العوامل الثقافية التي كان لها تأثير ها في دفع النظام التعليمي الياباني، ومنها الجامعات إلى الاهتمام بتعزيز الهوية الوطنية، ومن هذه العوامل، العامل الجغرافي؛ إذ تقع اليابان في شرق أسيا بين المحيط الهادئ وبحر اليابان، ولا يوجد لها حدود مشتركة مع أي دولة، بل إنه يحيط بها البحر من كل جانب وسلسلة جبال من الثرق والغرب(100)، ولقد جعلها هذا الموقع بعيدة إلى حد كبير عن دائرة الصراع والتوتر والاطماع الاستعمارية مما أضفى عليها طابع الهدوء و الاستقرار، وجعلها بعيدة إلى حد ما عن عو امل الاختراق الثقافي، وبالتالي قدرتها على الحفاظ على الهوية الوطنية، من جانب والتفرغ للتشيبيد و والبناء.

كما كان للعامل الثقافي في اليابان أثره في تعزيز الهوية الوطنية لأبنائها؛ فعلى الرغم من انفتاح اليابان على المجتمع الخارجي، إلا أنها تحرص دائما على أن يحتفظ أبناؤها بهويتهم الوطنية، وليس أدل على ذلك من ان السياسات التعليمية في اليابان قد سمحت بتعلم الطلاب اللغة الإنجليزية، إلا أنه وطبقا للمورثات اليابانية Nihonjinron، يُعد عدم القدرة على التحدث باللغة الإنجليزية دلالة على اليابانية النقية للفرد الياباني(107)، وهي اليابانية التي تحمل قيم ذات طابع خاص تميز المجتمع الياباني عن

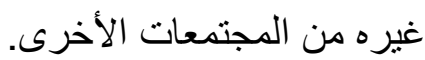
و هو ما جعل الثقافة اليابانية عُرضة لكثير من الانتقادات من قبل الغرب وخاصةً فيما يتعلق بقيمتي الاتفاق و التناغم بين أبنائها، في ظل توجهات يسودها الخضوع و الو لاء للجماعة، وهو ما حدا بكثير من المفكرين الغربيين إلى النظر إلى الثقافة اليابانية على أنها ثقافة غير عقلانية و غير منطقية وتابعة اجتماعياً، في الوقت الذي يرى فيه اليابانيون أن هذه الصفات هي دليل على سمو الثقافة اليابانية وتفوقها على غير ها من الثقافات.(lov)

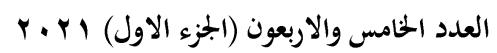

$(401)$
مجلة كلية التربية- جامعة عين شمس 
أثر برنامج إثرائي قائم على معايير العلوم اللجيل القادم (NGSS) في تنمية مهارات القرن الحادي والعشرين ونزء ات التفكير لاى طلاب الصف الثالث المتوسط المتفوقين ذوي المستويات المختلفة في معالجة المعلومات

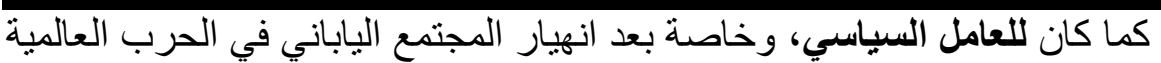
الثانية، وما نتج عنه من تغيير السلطات اليابانية لوجهة نظرها ونظرتها للعالم المحيط، و إعادة بناء علاقتها مع جير انها من الدول المحيطة، بل كل بلدان العالم أيضاً، تأثثيراً لا يمكن إنكاره، الأمر الذي جعلها تعيد بناء علاقاتها السياسية مع الآخرين، ورأت في اللغة سبيلاً لتحقيق ذلك، فعلى الرغم من اهتمامها باللغة العالمية الأولى التي تعتبر سبيل التفاهم التواصل مع الثقافات المتباينة، إلا أنها استطاعت تحقيق التوازن بين الاهتمام بتلك اللغة العالمية واللغة اليابانية على اعتبار أنها سبيل دعم الانتماء للثقافة اليابانية الأم، وتقدير مكونات الثقافة اليابانية، ومن ثم كان هناك، ومازال حتى وقتنا الحاضر، تأكيداً على استخدام اليابانية كلغة تدريس أساسية حتى بالمرحلة الجامعية، تدعيماً لأهمية شخصيتها القومية، وثقافاتها المتميزة أمام كل دول العالم.(101) ومع النمو الاقتصادي السريع والهائل لليابان في عقدي الخمسينيات والستينيات من القرن العشرين، وما نتج عنه من تحرر اليابان اقتصاديا من التبعية الأمريكية، نُفذت تحولات هامة في إيديولوجية الوعي الثعبي والرأي العام الياباني، وتولد لدى الثعب الياباني قناعة مفادها أن الغرب لا يمكنه أن يُملي على اليابانيين كيف يعيشون، و أنهر بما

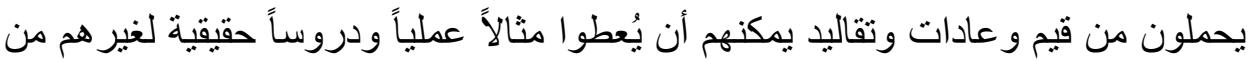
الشعوب، ومن هنا كبرت المشاعر القومية وبدأت تتمو مجدداً أفكار التراث والأصالة وقيم الآباء والأجداد. (109)، الأمر الذي يوضح أن السطوة والمكانة الاقتصادية الراسخة التي تميز بها المجتمع الياباني، وانعكس على الدخل القومي والمستوى المعيشي المتميز لليابانيين، اتاحت لليابان الفرصة لفرض مكانة ثقافاتها القومية، وهويتها الوطنية على

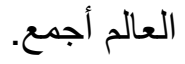
وبناء على ما سبق، يتضح أن ثمة عوامل متنوعة ساهمت في اهتمام المجتمع الياباني بدعم الهوية الوطنية لدى الطلاب اليابانيين بمختلف المراحل الدراسية بشكل 
د. ولاء السيد عبد الله السيد صقر د. يحيى مصطفى كمال الدين عام، وبمرحلة التعليم الجامعي على جه الخصوص، كما اتضح من العرض السابق، الأمر الذي أكد على أهمية دعم الهوية الوطنية للمجتمع الياباني، الذي ماز الت كل دول العالم تنظر لجهودها بعين الاحتر ام والتقدير.

القسم الرابع: تحليل مقارن تفسيري لوسائط جامعات دول الدراسة في تنمية الهوية الوطنية لاى طلابها

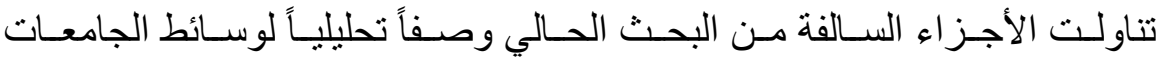

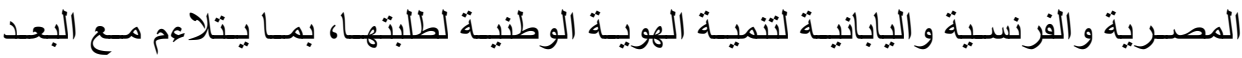
الوصفي، والبعد التحليلي للمنهج المقارن، ومن ثم يتناول القسم الحالي بيان أوجه التتــابه و الاختلاف بين الدول محل الدراسة والمقارنة بينها، يلي ذلك ووفقـاً للمنهـج المقـارن في بعده المقارن التفسيري، تفسير أوجه التشابه والاختلاف، وذلك على النحو التالي: 
أثر برنامج إثرائي قائم على معايير العلوم للجيل القادم (NGSS) في تنمية مهارات القرن الحادي والعشرين ونزعات التفكير لاى طلاب الصف الثالث المتوسط المتفوقين ذوي

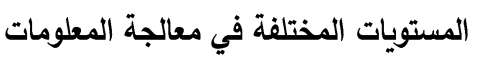

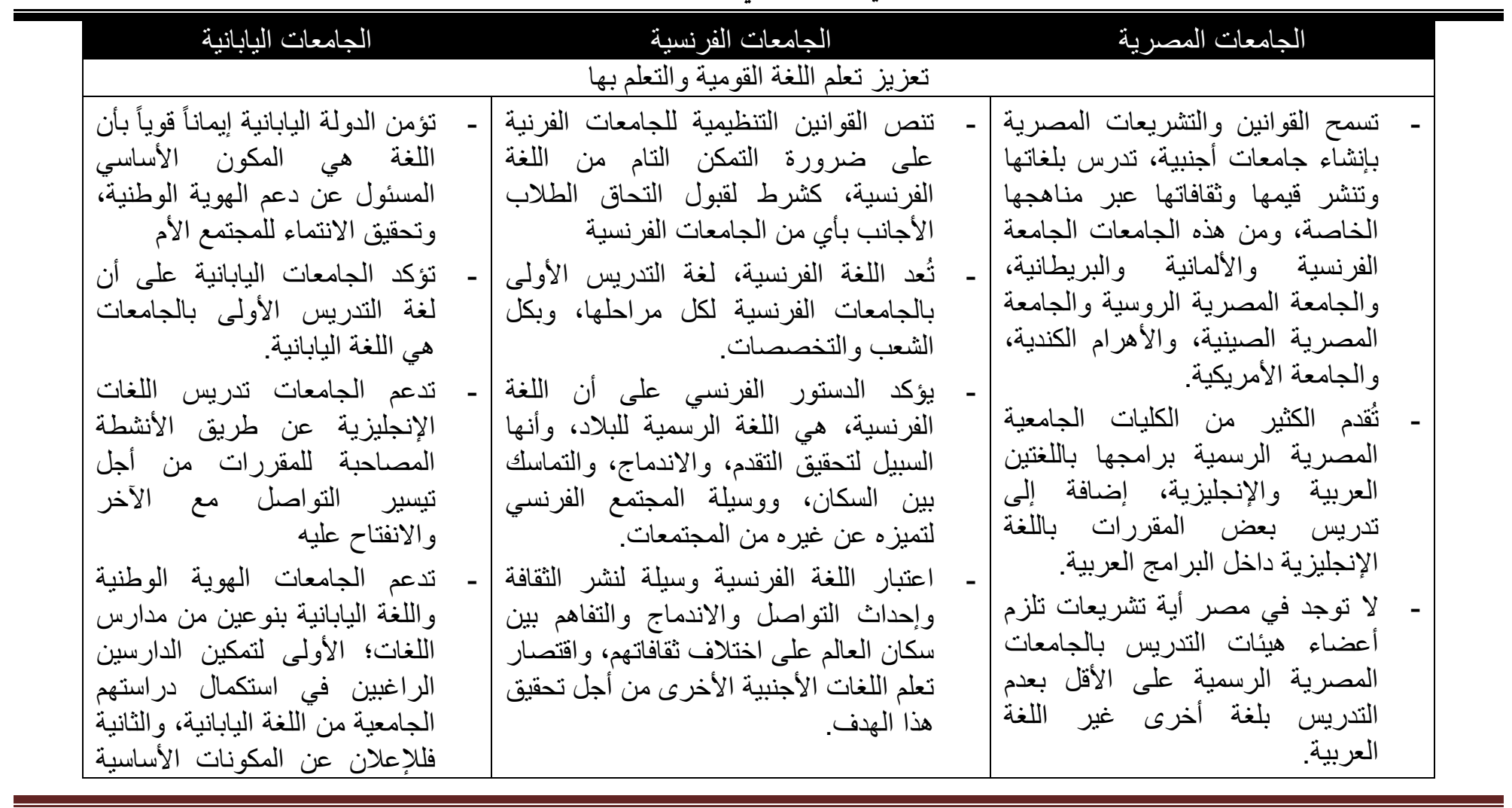

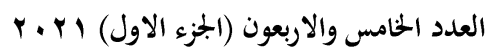

(404)

مجلة كلية التربية- جامعة عين شمس 
د. ولاء السيد عبد الله السيد صقر

د. يحيى مصطفى كمال الدين

\begin{tabular}{|c|c|c|}
\hline الجامعات اليابانية & الجامعات الفرنسية & الجامعات المصرية \\
\hline 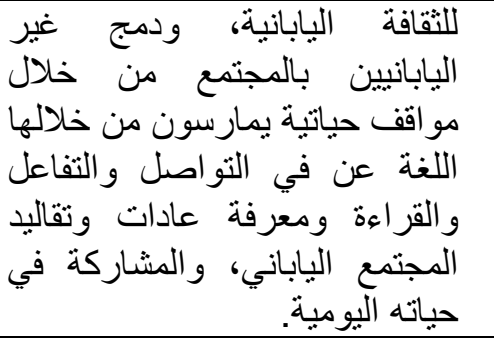 & & \\
\hline \multicolumn{3}{|c|}{ تدريس مقرر ات جامعية ذات صبغة وطنية } \\
\hline 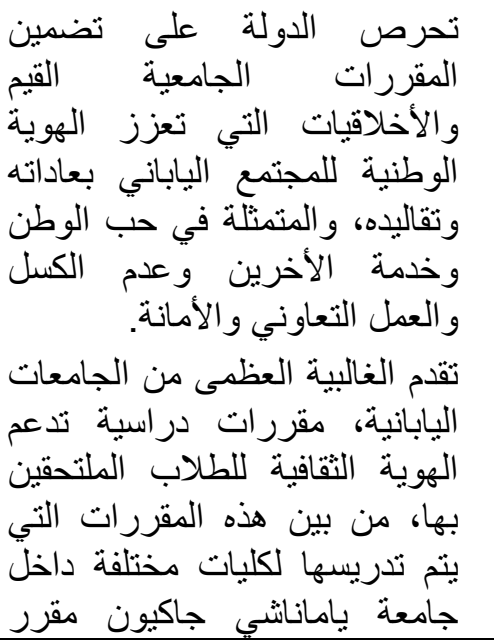 & 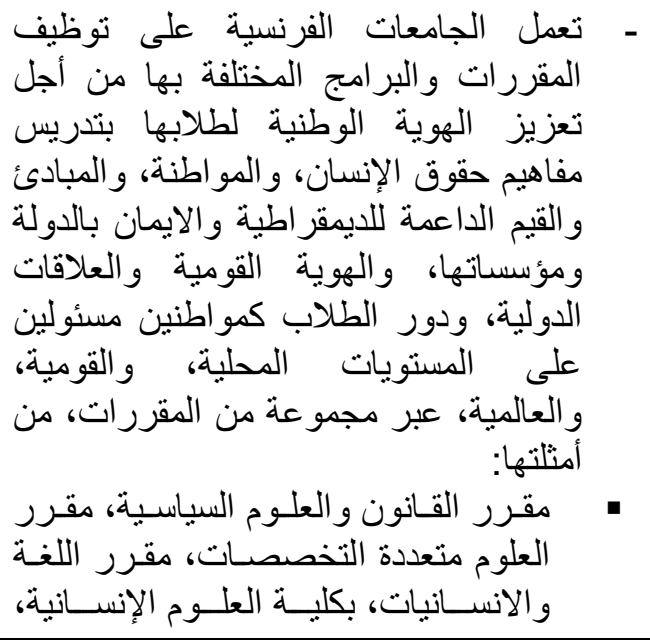 & 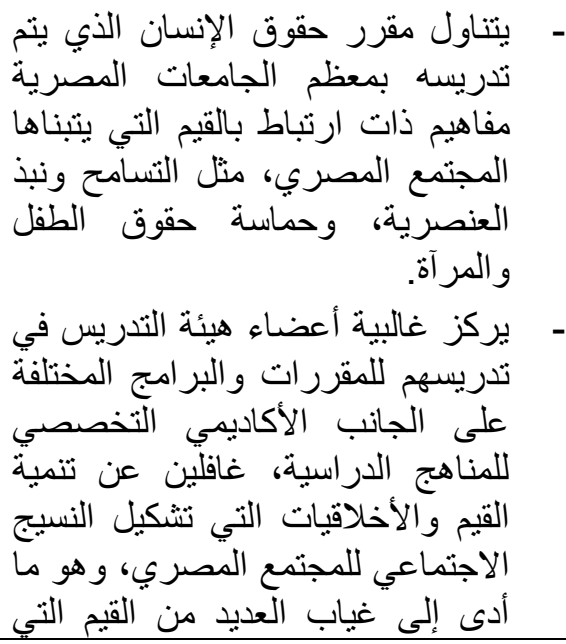 \\
\hline
\end{tabular}

العدد الخامس والاربعون (الجزء الاول) ا ب. r.

مجلة كلية التربية- جامعة عين شمس (405) 
أثر برنامج إثرائي قائم على معايير العلوم للجيل القادم (NGSS) في تنمية مهارات القرن الحادي والعشرين ونزعات التفكير لاى طلاب الصف الثالث المتوسط المتفوقين ذوي

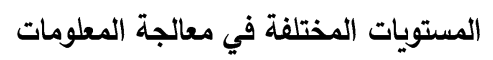

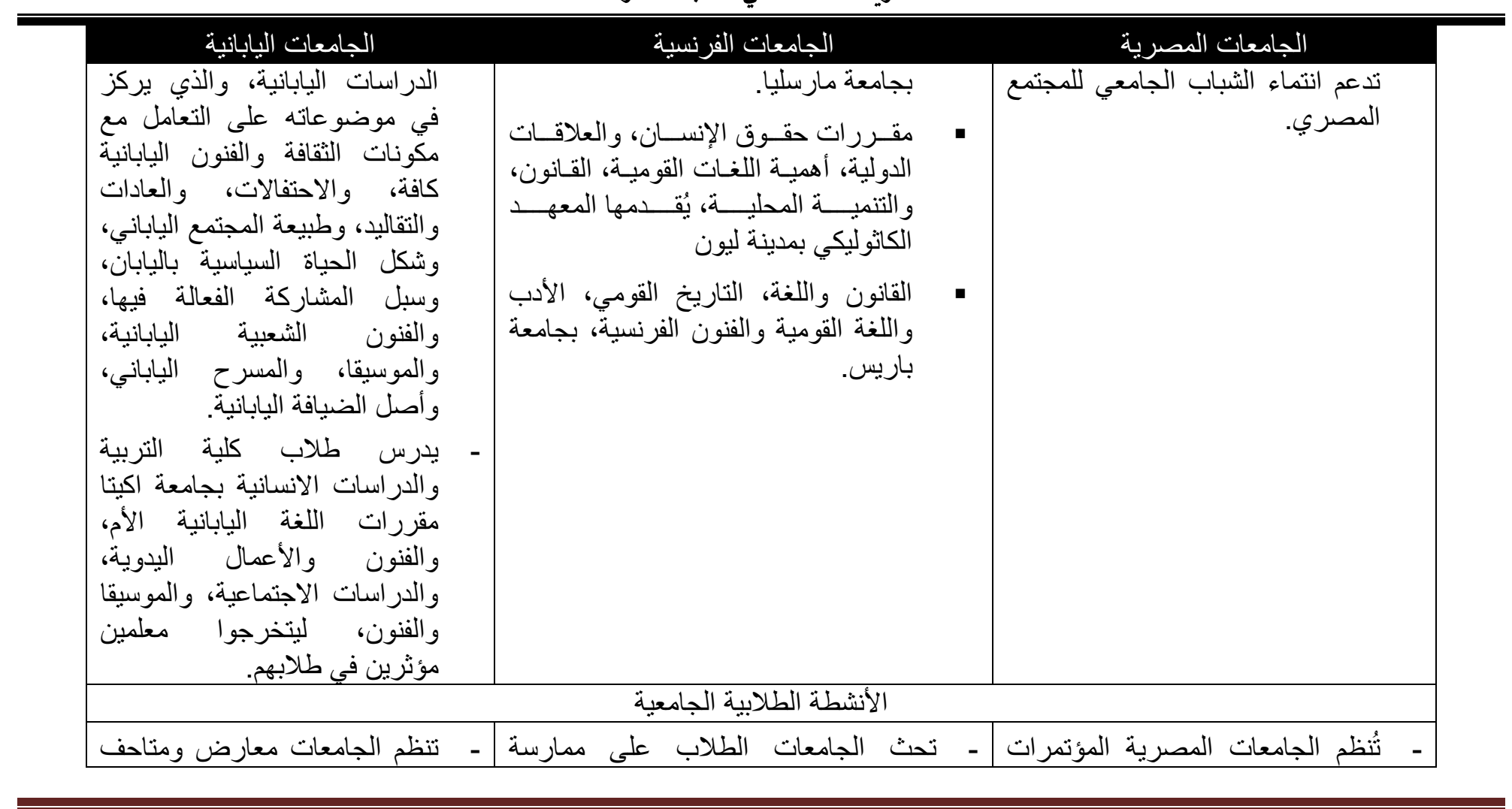




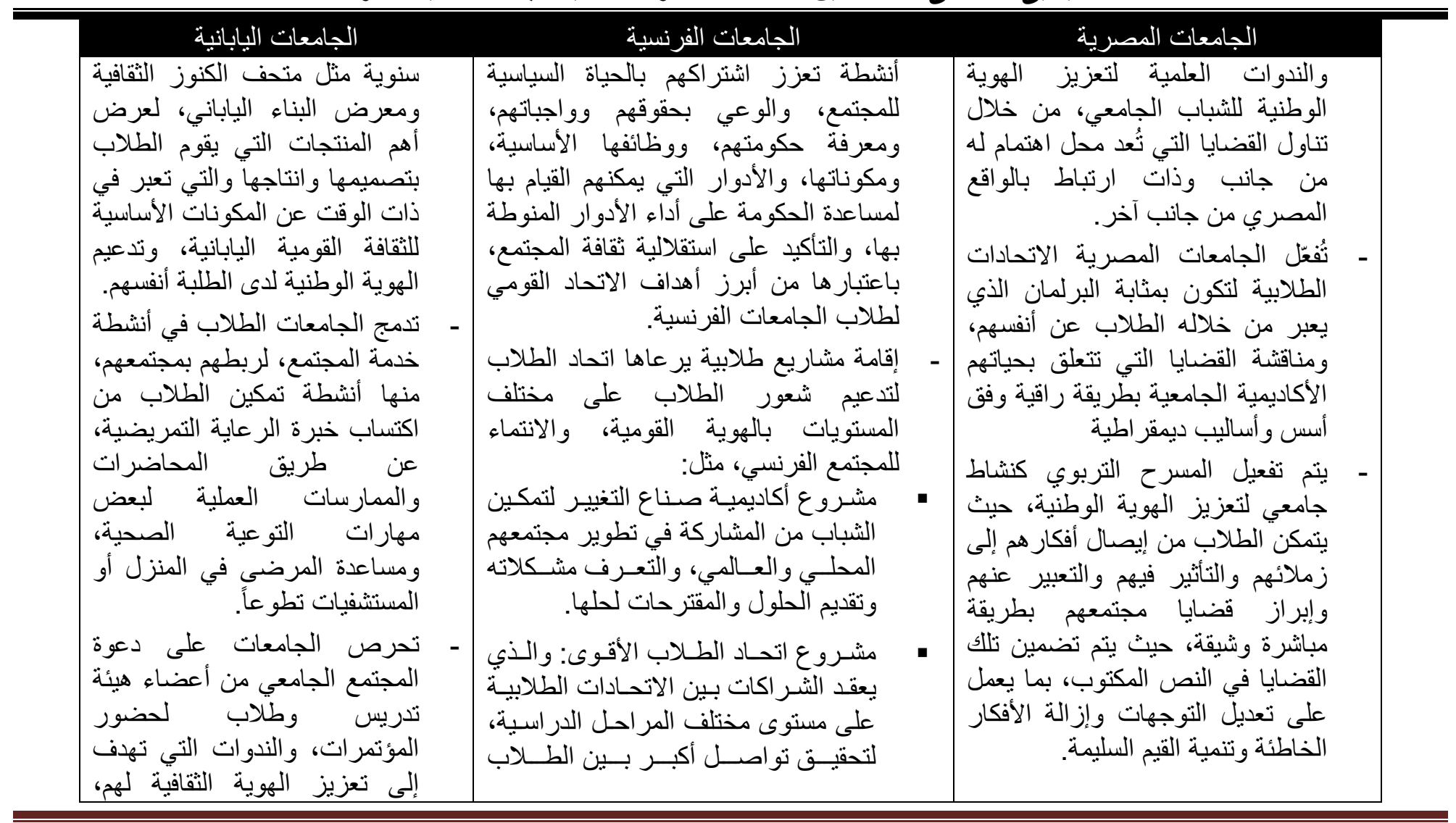


أثر برنامج إثرائي قائم على معايير العلوم للجيل القادم (NGSS) في تنمية مهارات القرن الحادي والعشرين ونزعات التفكير لاى طلاب الصف الثالث المتوسط المتفوقين ذوي

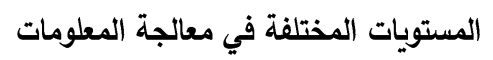

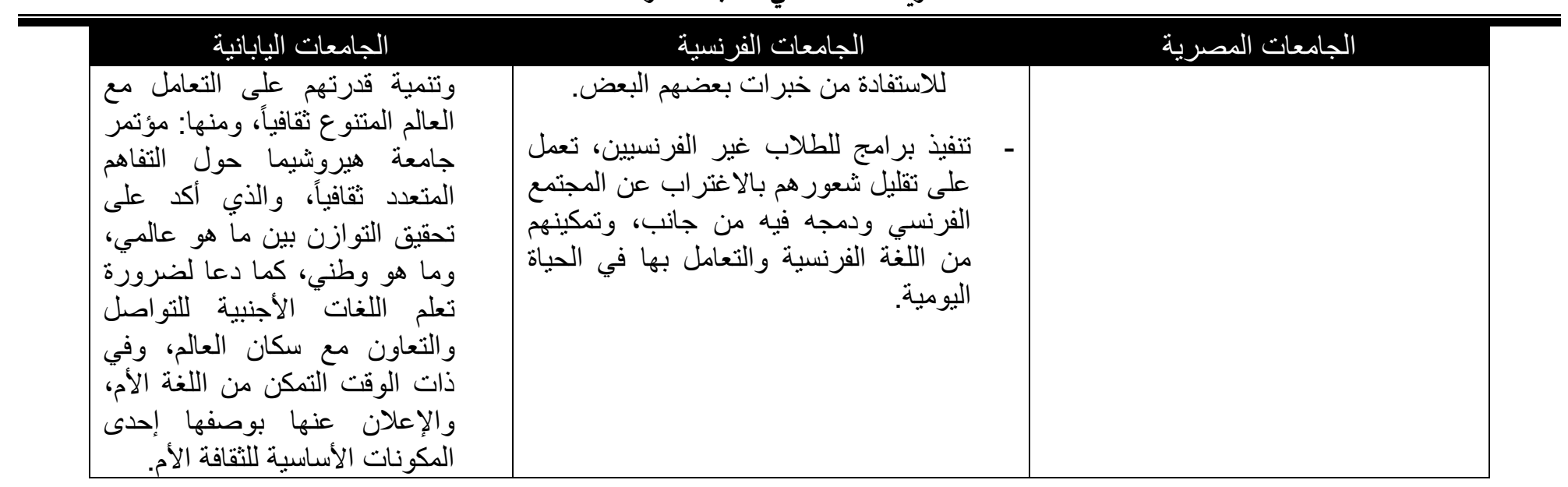


د. ولاء السيد عبد الله السيد صقر د. يحيى مصطفى كمال الدين

أوضحت المقارنة السالفة لوسائط الجامعات المصرية و الفرنسية واليابانية، أن هناك ولاءل العديد من أوجه التشابه والاختلاف بينها، ومن خلال ما يلي سوف يتم تفسير تلك الأوجه، وذذلك على النحو التالي:

فيبا بتعلق بتعزيز تعلم اللغنة القومية والتعلم بها. - أوجه التثابه وتفسير ها:

تشابهت كل من الجامعات الفرنسية واليابانية، في التأكيد على أن تكون اللغة القومية للاولة هي لغة التدريس الأولى في كل مراحل الدراسة الجامعية، وبجميع تخصصاتها العلمية، كما اتفقا على أن اللغة القومية للدولة وسيلة لنشر ثقافتها، وإحداث التواصل و التفاهم بين أبنائها وسكان العالم على اختلاف ثقافاتهم. ويتسق ذلك مع مفهوم الهوية الثقافية Cultural Identity، و التي تُعرف بأنها مجموعة من الأفكار و المعتقدات و العادات و التقاليد والاتجاهات و القيم وأساليب التفكير التي تمبز مجتمعا عن آخر، على أن جوهر الهوية الثقافية هي الثوابت الراسخة في الثقافة.(17) ويتجلى جوهر الهوية الثقافية في اللغة والأخلاق والدين وطبيعة الإقليم الذي يسكنه جماعة من الناس، تللك الخواص هي التي توزع النوع الإنساني إلى أقوام مميزين، بما

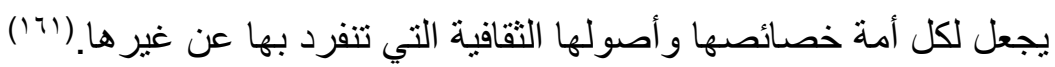
لذا فقد حرصت كلتا الدولتين على الحفاظ على هويتها الثقافية بتدعيم لغتها والحرص على أن تكون لغة التدريس الأولى في جميع البرامج والتخصصات، ذلك أن الحفاظ على الهوية الثقافية هو في ذات الأمر حفاظ على الهوية الوطنية للأمة. - أوجه الاختلاف وتفسبر ها:

اختلفت الجامعات المصرية عن كل من الجامعات الفرنسية اليابانية في هذا الصدد؛ حيث تقوم الكثبر من الجامعات الوطنية بتقديم بعض من مقرر اتها الدر اسية التي تتضمنها بر امجها باللغة الإنجليزية، إضافة إلى أن الكثير من الجامعات بها بر امج كاملة Cultural باللغة الإنجليزية. وهو ما يمكن تفسيره في ضوء مفهوم الاغتراب الثقافي 
أثر برنامج إثرائي قائم على معايير العلوم اللجيل القادم (NGSS) في تنمية مهارات القرن الحادي والعشرين

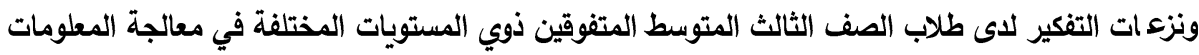
Alienation ذلك أنه بعد أن أحكمت العولمة قبضتها الاقتصادية والسياسية على العالم أخذت تتقدم نحو الهيمنة الثقافية لتستيح الكثير من مقوماته الثقافية ومنها اللغة القومية، وهو ما يقود إلى الاغتر اب الثقافي.(r) وقد أدت هذه الهيمنة إلى الكثير من المظاهر السلبية التي نراها في جامعاتتا وبين شبابنا، وهو ما أكد عليه بركات ج . . ؟، من أن هناك ارتباط بين الهيمنة الثقافية وما ينشأ عنها من اغتراب ثقافي، وبين تدهور المنظومة القيمية والأخلاقية في

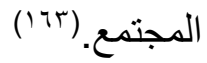

\section{فيبا يتعلق بتدربيس مقررات جامعية ذات صبغة وطنية.}

\section{- أوجه التشابه وتفسيرها:}

عملت الجامعات الفرنسية على تضمين مقرر اتها الدر اسية عددا من القيم و المفاهيم و المبادئ التي تعزز الهوية الوطنية في نفوس الطلاب؛ ولم يقف الأمر على مجرد تضمين المقررات لتلك القيم وإنما تجاوزت ذلك إلى إقرار مقررات ذات ارتباط بالهوية الوطنية مثل مقررات القانون والعلوم السياسية و اللغة و علوم الإنسانيات وحقوق الإنسان و العلاقات الدولية والتنمية المحلية والتاريخ والفنون والآداب، مؤكدة على أن يعي طلابها مفاهيم حقوق الإنسان، والمواطنة، ومبادئ الديمقراطية وقيمها، و القواعد الأساسية للحياة السياسية والاجتماعية، وأن يعرف الطلاب حقوقهم وواجباتهم، ولقد تشابهت بذلك مع الجامعات اليابانية، التي حرصت هي الأخرى على تضمين قيم المجتمع الياباني في المقررات الدراسية الجامعية لتنشئة أجيال تقدر قيم المجتمع وتحترمها، و إقرار مقررات ذات ارتباط بالهوية الوطنية مثل مقرر الدراسات اليابانية، و الذي يتناول مكونات الثقافة اليابانية، ومقرر الفنون الثعبية اليابانية، والموسيقا، 
د. ولاء السيد عبد الله السيد صقر د. يحيى مصطفى كمال الدين

و المسرح الياباني، وأصل الضيافة اليابانية، ومقررات اللغة اليابانية الأم، والفنون و الأعمال اليدوية، والدراسات الاجتماعية، و الموسيقا و الفنون والئن ويمكن تفسير ذلك في ضوء مفهوم المواطنة، حيث تُعرف المواطنة، بأنها الانتماء التاريخي والثقافي والحضاري لبلد معين والثعور بالتعلق به أكثر من غيره، كما يثير إلى الحقوق و الواجبات و المبادرات والمسؤوليات تجاه النفس والبلد الذي ينتمي إليه الفرد.(צ'1). كما تُعرف المواطنة Citizenship، بأنها الدور الإيجابي للفرد بصفته مواطناً، وقد أكّد الفيلسوف روسو على أن مفهوم المواطنة يعتمد على ليى دعامتين أساسيتين هما المشاركة الإيجابية من جانب الأفر اد في عملية الحكم، والمساوة الكاملة بين أبناء المجتمع من جانب آخر . (170) ولذلك فإن تأكيد كل من فرنسا واليابان على أن تتضمن المقررات الدراسية الجامعية المبادئ التي يقوم عليها المجتمع و المفاهيم التي يتبناها والقيم التي يؤمن، إنما هي دعوة لتكوين جيل يُحقق المواطنة الصالحة تجاه نفسه ومجتمعهد.

$$
\text { - موجه الاختلاف وتفسيرها: }
$$

يشير الواقع في مصر، إلى أن بعض الجامعات قد أقرت تدريس مقرر حقوق الإنسان في بعض من كلياتها، إلا أن هذا التدريس يكون للمفاهيم و المبادئ العامة، دون عكس لتلك المبادئ على الواقع الذي يعيشه الطلاب، كما أن غالبية أعضاء هيئة التدريس يهتمون بالجوانب الأكاديمية للمقررات التي يدرسونها غافلين عن الجوانب القيمية والأخلاقية، وهو ما كان له انعكاسه السلبي على استشعار طلاب الجامعات للقيم الوطنية والأخلاقيات التي يتبناها المجتمع المصري، الأمر الذي يوضح أن ثمة اختلاف بين الواقع المصري، وو اقع الجامعات الفرنسية واليابانية. ويمكن تفسير ذلك في ضوء ضعف الوعي بأهمية بقيمة الهوية الوطنية ومكوناتها من جانب، والثعور بالهزيمة النفسية الداخلية عند الثباب من جانب آخر، فعلى الرغم من أن مصر هي قلب الأمة العربية النابض، وعلى الرغم من أن الأزهر الذي كان 
أثر برنامج إثرائي قائم على معايير العلوم اللجيل القادم (NGSS) في تنمية مهارات القرن الحادي والعشرين

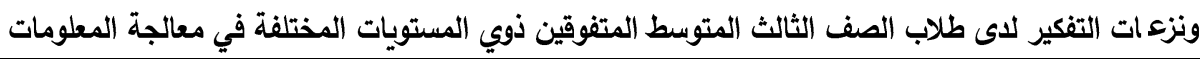

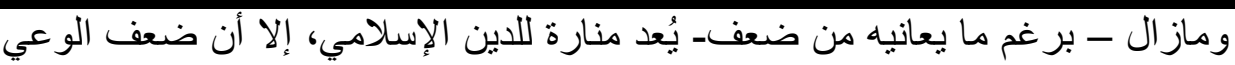
بهذه المكانة أضعف الجهود التي تُبذل من أجل التأكيد عليها وغرسها في نفوس أبناء المجتمع المصري وتحديدا في نفوس شبابه، وهو ما انعكس على شعور هم بالهزيمة النفسية والانكسار أمام المجتمعات الأخرى التي يرونها في قمة ازدهار ها ونشاطها، من حيث إنتاجها الصناعي و الاقتصادي و الثقافي.

كما يمكن تفسير ذللك أيضاً في ضوء مفهوم عجلة المستقبلات Futures Wheel و هو مفهوم يشير إلى أسلوب لتنظيم الأفكار، والتساؤلات حول المستقبل من خلال حصر الآثار المباشرة، و غير المباشرة المحتملة لقضية ما.(T4) حيث تتظر دائما الدول المهتمة بتنمية الهوية الوطنية كفرنسا واليابان، للمقررات الدراسية على أنها السبيل لدعم الأفكار الإيجابية الخاصة بالانتماء وغير ها في عقول الطلاب، كما كانت في السابق، فقد كانت تللك المقررات، السبيل لتشكيل عقليات الطلاب أوقات الأزمات التي تعرضت لها تلك الدول، وخاصة عند التفكير في كيفية تشكيل هويات وعقليات الطلاب اليابانيين بعد الحرب العالمية الثانية، فالتاريخ عبارة عن دائرة مستمرة، وقد تعود أحداثه التي حدثت في حقبة زمنية معينة في حقبة زمنية أخرى، ومن ثم اهتمت تللك الدول بالمقررات الدراسية وما بها من أفكار، فهي السبيل لدعم الأفكار الإيجابية في الوقت الحالي، وفي المستقبل أيضاً، كما كانت في الماضي، وربما لم يكن لمصر ذات الاهتمامات في هذا الصدد، لأنها لم تستخدم المقررات الدراسية بذات القوة في إطار ذات الاتجاه التي استخدمتها الدول محل الدراسة في أوقات أزماتها، أي أن العجلة المستقبلية لم تسر في ذات المسار الذي سارت فيه الدول الأجنيية، ومن ثم لم تلق المقررات الجامعية المصرية ذات الاهتمام، كما كان الحال

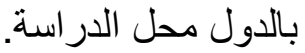


اتفقت جهود الجامعات المصرية والفرنسية واليابانية في التأكيد على أهمية الأنشطة الطلابية في تعزيز الهوية الوطنية لطلاب الجامعات، إلا أنهم تباينوا في هذه

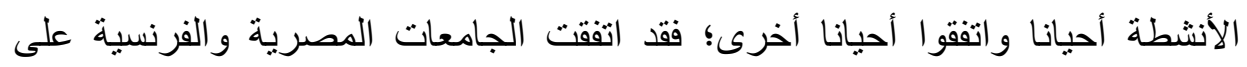
تفعيل الاتحادات الطلابية لتكون صورة من صور تعبير الطلاب عن أنفسهم، ولتدريبهم على المشاركة في الحياة السياسية والوقوف على حقوقهم وو اجباتهم داخل المجتمع ومن

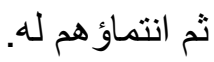

و هو الأمر الذي يمكن فهمه في ضوء مفهوم المشاركة السباسية Political

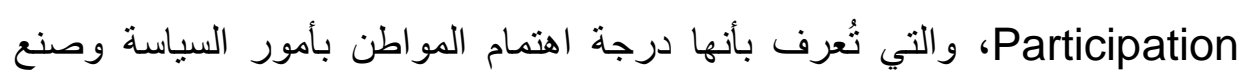
القرار، فكلما زادت المشاركة السياسية من قبل المواطنين كلما زادت قوة القرار السياسي، كما أن المشاركة السياسية تقلل صور العنف في المجتمعات التي تتوسع فيها

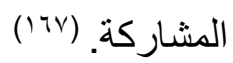

بينما انفردت اليابان بتنظيم المتاحف والمعارض التي تعبر عن مكونات الثقافة

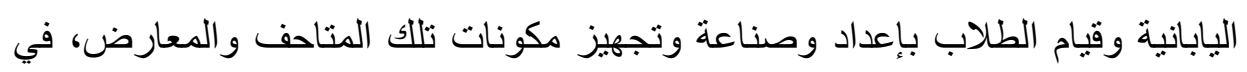
خطوة منها لتعزيز وعي الطلاب بتر اثهم و الوطني وليكونوا أكثر قدرة على التعبير عنه ونه

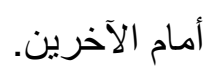

ويمكن تفسير اهتمام الجامعات اليابانية بتنظيم تللك المتاحف و المعارض في إطار مفهوم الثخصية القومية National Character و التي يُقصد بها القيم الاجتماعية و الاتجاهات السلوكية والفكرية والثقافية و الحضارية السائدة في مجتمع ما، والتي تسود

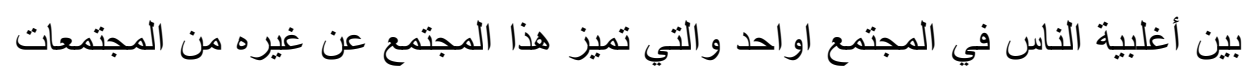

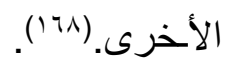

لذا فقد حرصت الجامعات اليابانية على أن يكون للطلاب دور بارز في الحفاظ

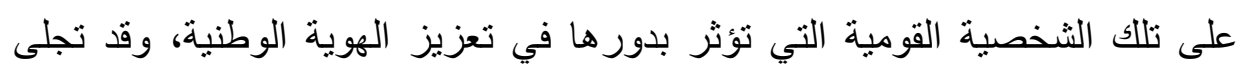


أثر برنامج إثرائي قائم على معايير العلوم اللجيل القادم (NGSS) في تنمية مهارات القرن الحادي والعشرين

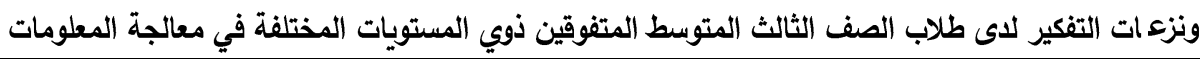
حرص الجامعة في أن يقوم الطلاب بأنفسهم بتصنيع وتشكيل وتجهيز ما سيتم عرضه لهنه في المعارض والمتاحف الجامعية، وهو ما يتطلب من الطاب أن يقرؤوا ويفهموا ويعوا تر اثهم بشكل جيد قبل أن بعبروا عنه بمنتجاتهم التي سيتم عرضها، و هو ما يتطلب منهم فهم تاريخهم بشكل جيد. فالثخصية القومية لمجتمع ما ترتبط بالخصائص التاريخية

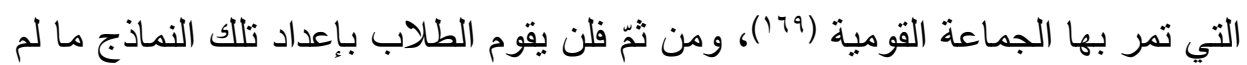
يكونو ا على قناعة بها. وفي خطوة مقابلة لما تقوم به اليابان من تنظيم للمتاحف و المعارض، نظمت الجامعات المصرية المؤتمرات الطلابية التي يتم فيها تبادل أطراف الحوارات في القضايا الوطنية بما يعمل على تعديل سلوكيات الطلاب وتغيير قناعاتهم من خلال

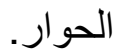

و هو ما يمكن تفسيره في ضوء مفهوم الألعاج الاجتماعي Social Inclusion للدولة القومية، ليعلو فوق كافة الولاءات الفرعية، بحيث يشعر المجتمع باختلاف عرقياته بأنه كل متكامل، وذلك باستخدام أدوات سياسية واجتماعية واقتصادية لتحقيق

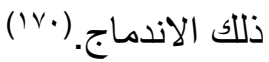

بينما انفردت الجامعات المصرية بأنشطة المسرح التربوي كنشاط جامعي لتعزيز الهوية الوطنية، يُمكن الطلاب من إيصال أفكار هم، والتعبير عن قضايا مجتمعهم و إبراز ها بطريقة غير مباثرة، بما يُسهم في تعديل التوجهات و إزالة الأفكار الخاطئة وتتمية القيم السليمة لاى الطلاب من ناحية، والإشارة إلى المشكلات المجتمعية من جانب آخر.

وعلى الرغم من أن المجتمع المصري لا يحوي عرقيات مختلفة أو كيانات متناحرة، إلا أن إتاحة الفرصة أمام طلبة الجامعة على اختلاف توجهاتهم السياسية 
د. ولاء السيد عبد الله السيد صقر د. يحيى مصطفى كمال الدين

و الفكرية، للمناقثنة والحوار في القضايا الوطنية المختلفة، والتعبير عنها بأثكال مختلفة من بينها المسرح التربوي، من شأنه أن يوجد قاعدة مشتركة بينهم، بحيث تعمل تللك القاعدة على احتر ام كل طرف للأخر وتقبله و التعايش مع فكره، بل إن هذا الحوار يُنتيح الفرصة للانفتاح على الأفكار المغلوطة لدى البعض، والمناقشة حولها وبيان خطئها، ومن ثمّ تتغير أفكار هم وتتعدل سلوكياتهم ويحدث اندماجهم تحت مظلة الوطن الواحد و القومية المشتركة.

\section{القسم الخامس: إجراءات مقترحة لتنمية وسائط الجامعات المصرية في تنمية الهوية}

\section{الوطنية لاى طلابها}

أظهرت الخطوات السابقة، أن هناك مقومات أساسية للهوية الوطنية هي اللغة و المعتقدات و التاريخ و الحضارة (التراث)، وأن للجامعات وسائط هامة تستخدم في تنمية الهوية الوطنية للشباب من أبناء المتمع، خاصة أنهم في المرحلة العمرية الأكثر تأثراً بالمتغيرات المحيطة، كما اتضح أن الجامعات يمكنها أن تستخدم تللك الوسائط من خلال التأكيد على اللغة بتعزيز تعلمها والتعلم بها، وبتوظيف المقررات والبرامج الدراسية لإبراز تاريخ الأمة وتراثها وما يشمله من قيم وعادات وتقاليد وطبائع وسلوكيات هي نتاج للتفاعل المجتمعي وانعكاس لمعتقداته التي بؤمن بها، كما بيّنت الخطوات السابقة وسائط الجامعات المصرية و الفرنسية واليابانية في تنمية الهوية الوطنية لدى طلابها، و اتضح كيف أن للجامعات المصرية جهود لا يمكن إنكار ها، إلا أن هناك ثمة قصور في بعضها وضعف في بعضها الآخر، وفي هذه الخطوة يشير البحث لعدد من الإجراءات المقترحة لتعزيز الهوية الوطنية لطلبة الجامعات المصرية، وذلك في ضوء الدهاء الدراسة النظرية والمقارنة، وبما يتلاءم مع السياق الثقافي للمجتمع المصري، ويمكن تنظيم الإجر اءات المقترحة على النحو التالي: 
أثر برنامج إثرائي قائم على معايير العلوم للجيل القادم (NGSS) في تنمية مهارات القرن الحادي والعشرين

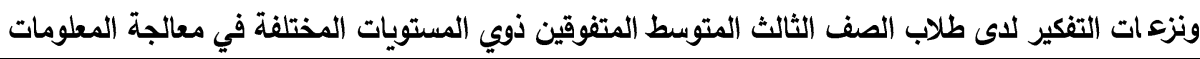
أولاً: فيما يتعلق بتعزيز تعلم اللغة القومية والتعلم بها.

- إجر اء عملية مر اجعة شاملة للبر امج الدراسية بالجامعات المصرية، للتأكيد على أم تدريس المقررات الدراسية المتضمنة بها، باللغة العربية الفصحى، ما لم يكن هناك سبب منطقي لأن يتم تدريس تلك المقررات بلغات أجنبية. - إجر اء عملية مراجعة للمحتوى العلمي المتضمن بالبرامج والمقررات التي يتم تدريسها بلغات أجنبية؛ لنتقيته من كل ما يتعارض مع الهوية الوطنية للجنمع المصري، بالكثف عن المفاهيم، والأفكار المغلوطة، والقيم السلوكية غير المرغوبة مجتمعياً، وما تبثه، أو تتجع عليه بعض محتوياتها -إن وجد-من عادات تتعارض مع عادات المجنمع. - التأكيد على أعضاء هيئة التدريس الذين يدرسون التخصصات العلمية، و الإنسانية

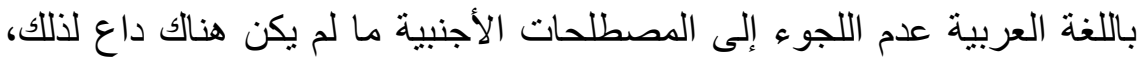
ذلك أن الطلاب عندما يرون أن أساتذتهم منبهرين باللغات الأجنبية، وعازفين عن لغتهم العربية في تدريسهم لمقرراتهم، سيعزفون هم أيضاً عن التواصل باللغة العربية فيما بينهم، وهو ما يؤدي إلى اندثار مقوم أساسي من مقومات الهوية الوطنية. - تدعيم تمكن الطلبة من اللغة العربية، وذلك بأن تقوم الجامعات المصرية بتدريس مقرر تحت عنوان مبادئ اللغة العربية باعتبارها اللغة الأم للدولة، لطلاب السنة الأولى، وأن يتولى أساتذة متخصصون إعداد المحتوى العلمي لهذا المقرر؛ لكي يخرج بطريقة بعيدة عن الملل والتكرار، و أن بتضمن بديع اللغة في النثر والثعر و القراءة، وأن تتضدن موضوعاته المجتمع المصري وتاريخه وثقافته بصورة إيجابية. 
- - التأكيد على الاحتفال باليوم العالمي للغة العربية، من خلال تفعيل مشاركة الطلبة وأعضاء هيئة التدريس في هذا الاحتفال بالمساجلات الشعرية، واللطائف اللغوية، و التوظيف المتمكن للغة، هذا بالإضافة إلى عقد مسابقة حول أفضل صياغة لبعض الترجمات من الإنجليزية إلى العربية. ثانياً: فيما يتعلق بالمقررات الدراسية:

- الحرص عند وضع المناهج الجامعية وتنفيذها على أن تتضمن تلك المناهج معارف نظرية وأنشطة عملية كافية؛ لغرس مفهوم الهوية الوطنية، وتجذير الولاء الوطني، ومن أمثلة ذلك مقررات مثل مقرر حقوق الإنسان، وأنظمة المجتمع، والعمل التطوعي، ناهيك عن تعليم اللغة الأم وبيان قوتها وأهميتها، و التعليم المقررات الأخرى بها. - تضمين المناهج الدراسية الجامعية مفردات المواطنة الصالحة، و القيم المجتمعية، وقبول الآخر، ومبادئ حقوق الانسان، واحتر ام القانون، و التأكيد على قيم الثفافية و النزاهة، و غير ها من مكونات الهوية الوطنية للهجنمع المصري. - تتجيع البرامج الدراسية للكليات المختلفة على أن تتناول موضوعات تبرز التراث الوطني للمجتمع المصري و إيجابياته، وما بحمله من عادات وقيم ودروس وقصص، وبيان مردود ذللك على كافة الأصعدة الاجتماعية والثقافية و الاقتصادية، من أجل تشكيل جيل واع بأهمية التراث الوطني. - - صياغة بر امج أكاديمية وبحثية يكون فيها التنظير مقترناً بالتطبيق، ويكون هدف هذه البرامج هو خلق ثقافة مجتمعية موحدة، بما يؤدي إلى تماسك طبقات

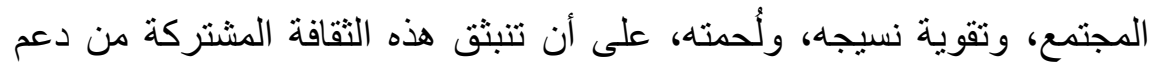
الهوية الوطنية، والتمسك بالقيم، والأخلاق، والعادات المستمدة من التاريخ

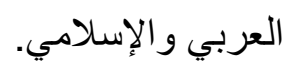


أثر برنامج إثرائي قائم على معايير العلوم للجيل القادم (NGSS) في تنمية مهارات القرن الحادي والعشرين ونزء ات التفكير لاى طلاب الصف الثالث المتوسط المتفوقين ذوي المستويات المختلفة في معالجة المعلومات

- تشجيع أعضاء هيئة التدريس على تتفيذ بحوث، ودراسات تتناول الموضوعات، و المفاهيم المرتبطة بمقومات الهوية الوطنية، ودعمهم في نشر ها محلياً ودولياً، وأن تقوم الجامعة بتلخيص وطباعة المتميز منها، وتوزيعه على الطلاب للإفادة منه. - - أن تحرص الجامعة على تبني أعضاء هيئة التدريس قيم المجتمع وتقاليده

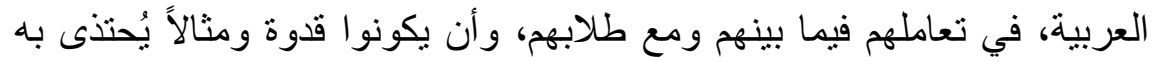
في سلوكياتهم، وأن يحمسو ا طلابهم على أن يتسموا بالأخلاق الكريمة، و الصفات الحسنة التي تعبر عن قيم المجتمع، وذلك بتكريم هؤلاء الطلاب و الإشادة بهم أمام زملائهم. - أن يؤكد أعضاء هيئة التدريس في محاضر اتهم على قيمة التراث الوطني، وقيمته الاقتصادية، والاجتماعية، والثقافية، ودوره في توفير وظيفية بما يمكن من ترغيب الطلبة ودعمهم للعمل بها. - تعزيز المسؤولية الاجتماعية للجامعة من خلال معرفة الاحتياجات العامة للمجتمع، وترجمتها إلى أنشطة عملية وتعليمية تقدمها من خلال طلابها و المنتسبين إليها، (الاستشارات العلمية- الأعمال التطوعية ــ اللقاءات التربوية و الثقافيةـ الاحتفالات بالمناسبات الوطنية- إبراز النجاحات لأبناء الوطن) و هي الوني بذلك تؤكد على قيم المجتمع وأخلاقياته في تقديم يد العون والمساعدة لأبناء

$$
\text { المجتمع. }
$$

\section{ثالثا: فيما يتعلق بالأنثطة الطلابية الجامعية:}

- - نشر الوعي بين منسوبي الجامعة بأن الفعاليات و المناشط الوطنية والاجتماعية، مصدر أساسي من مصادر تعزيز الهوية الوطنية لدى الثباب، ومن ثمّ تجب مر اعاتها وإعدادها وتتفيذها بشكل صحيح، وألا يُنظر إليها على أنها ترف لئه جامعي لا فائدة منه. 
- تنفيذ نشاطات ومهرجانات تتناول المناسبات الوطنية وتاريخ مصر، وتبرز علمائها ورجالاتها المتميزين على مدى التاريخ؛ لزرع الثقة في نفوس الطلبة بوطنهم ومكانته، وجعلهم أكثر فخرا واعتزاز به، وحفزهم على بذل الجهد للمشاركة في النهوض بوطنهم والحديث عن مآثره ومناقبه، و إبراز دور مصر المحلي و الإقليمي والدولي، وتمثيلها كنماذج مشرفة و علماء بارزين. - تنظيم المسابقات الطلابية والأنشطة الجامعية التي تعزيز الانتماء، حيث يتعرف الطالب في كل مناسبة على معلومة جديد عن وطنه، ويترسخ في نفسه معنى أجمل عن هذا الوطن وما قام به أبناؤه من أجل الحفاظ علية، والذود عنه - تفعيل مشاركة الطلاب في الأنشطة المجتمعية النطوعية على اختلافها، والتي تعزز انتماء الثباب لمجتمعهم، مثل المشاركة في الحملات البيئية والصحية و التوعوية، والمساهمة في أنشطة حماية التراث الوطني والحضاري بدء من الحضارة الفرعونية مرورا بالمعالم الأثرية المسيحية والحضارة الإسلامية

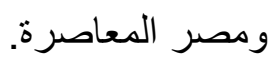
- تنظيم زيارات للمناطق الأثرية الواقعة ضمن نطاق كل جامعة، والتنسيق مع هيئة الآثار و السياحة للإعداد لتلك الزيار ات، بحيث يُقام للطلاب برنامج يحكي تاريخ كل منطقة أثرية، وكيف نشأت وتكونت تلك الحضارة المصرية العريقة، وبيان كيف أن مصر كانت مستقر اً لكثير من أنبياء الله الذين سكنو ها أو مروّ بها. - تنفيذ معارض طلابية جامعية تحكي تاريخ الدولة المصرية وتبرز عادات المجتمع المصري وقيمه، على أن تكون محتويات تلك المعارض من تنفيذ الطلاب أنفسهم. - عقد مسابقات على مستوى الجامعات بين الطلاب بحيث يُقام طلاب كل جامعة معرضا منميزا يعبر عن ملامح المدينة التي تقع بها الجامعة، والآثار التي 
أثر برنامج إثرائي قائم على معايير العلوم اللجيل القادم (NGSS) في تنمية مهارات القرن الحادي والعشرين

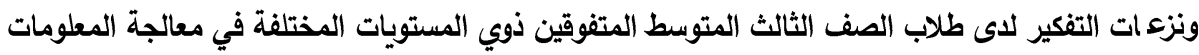

تضمها، و المنجزات التم تمت بها و النهضة التي تشهدها، وأن تشمل المسابقة أفضل صورة و أفضل مقطع مصور عن المدينة وعن المجتمع المصري ككل. - إقامة أعضاء هيئة التدريس بالجامعة لندو ات، وحلقات نقاثية، ومؤتمرات تتناول الدولة المصرية في علاقتها بالعالمين العربي والإسلامي، وجهودها على المستوى القاري والدولي، كما تتناول الإشارة إلى عدد من القضايا منها: استر اتيجية الأمن القومي، ومعنى الدولة ومقوماتها، وحروب الجيل الرابع، وماذا يحدث في سيناء، والعالم الافتر اضي وحروب الثائعات، و الأمن المائي وترشيد استهلاك المياه، بما يعزز الجوانب المعرفية، والمهارية والوجدانية عند الطلاب تجاه وطنهم، وتاريخه، وتراثه والمخاطر التي يو اجهها و التحديات التي يعمل على تخطيها، وهو ما يجعلهم أكثر بقضايا وطنهم، وتمسكاً به و الزود عنه. - تفعيل دور الأسر الطلابية بالجامعات في ممارسة العمل المجتمعي كمثلين عن الطلاب، بما يدعم وعيهم بالو اقع السياسي للمجتمع المصري، وبما يدربهم على كيفية المحافظة على حقوق الطلاب و المطالبة بها بأسلوب راق، وعلى الجانب الاخر القيام بواجباتهم و الاضطلاع بالمسؤوليات التي أصبحو الملزمين بها بحكم تمثيلهم لإخوانهم الطلبة. - تفعيل أنشطة المسرح التربوي بالجامعات المصرية بصورة أكبر، بحيث تُقدم نصاً مسرحياً هادفاً يتناول القضايا المجتمعية، ويعرض للثقافة المصرية وتاريخها العريق، ويُرز عاداتها وقيمها الإيجابية متجاوز التلك القيم السلبية التي بدأ تظهر في الوقت الحالي، حتى لا يسمح لها بالانتشار، ويؤكد على ان تلك القيم الإيجابية هي التي شكلت في يوم من الأيام القوة المجتمعية لمصر الحضارة

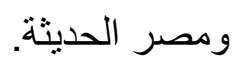


د. يحيى مصطفى كمال الدين د. ولاء السيد عبد الله السيد صقر

$$
\text { المراجع }
$$

(') محمد عمارة (999 (م). مخاطر العولمة على الهوية الثقافية، طا. القاهرة: دار نهضة

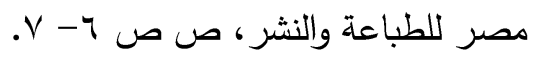

(Theories of Human Littlejohn, Stephen W. and Karen A. Foss. (2008). Communication. 9th ed. Belmont. P. 89.

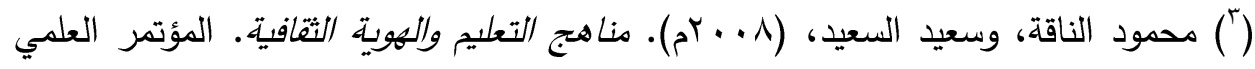
العشرون: التعليم والهوية .القاهرة، دار الضيافة بجامعة عين شمس، ص • .

(4) Anderson, B. (1983). Imagined Communities: Reflections on the Origin and Spread of Nationalism. London, UK: Verso Editions. P. 133.

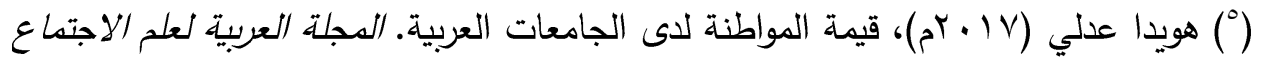

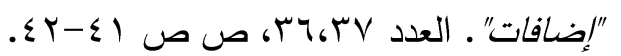

( ) وزارة التعليم العالي والبحث العلمي (0 1 ـ بم). استراتيجية وزارة التعليم العالي والبحث العلمي في

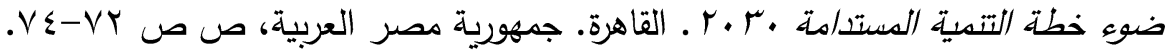
(7) وزارة التعليم العالي والبحث العلمي، (ד أ (rم)، الاستراتيجية القومية لتطوبر التعليم العالي

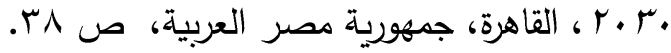

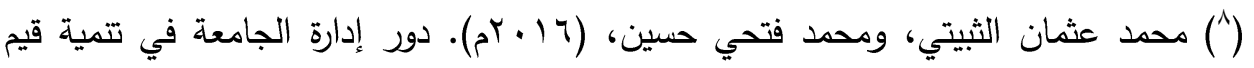

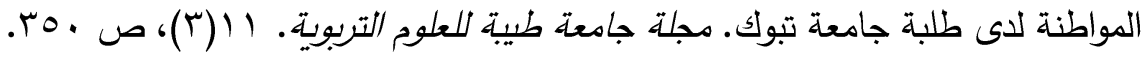

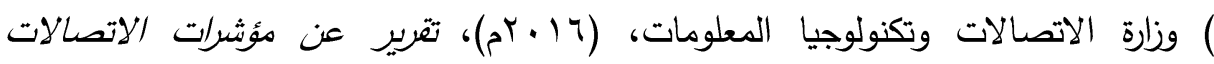

وتكنولوجيا المعلومات، القاهرة، وزارة الاتصالات وتكنولوجيا المعلومات، ص VY.

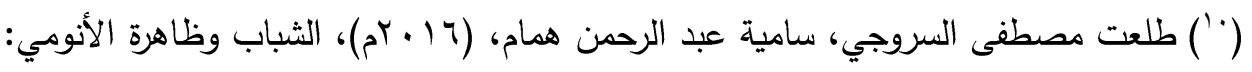
قراءة في صراع الهوية القومية والعالمية، مجلة كلية الخدمة الاجتماعية للدراسات والبحوث

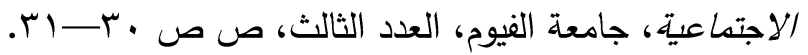
(') إيمان عبد الراضي، ودروش محمد درويش (Tا + rم) تعليم المواطنة في المملكة المتحدة وسبل الاستفادة منها في واقعنا التعليمي: دراسة تحليلية. مجلة كلية التربية بالسوبس.

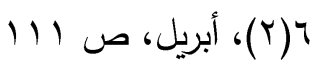

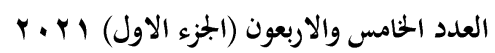

$(421)$
مجلة كلية التربية- جامعة عين شمس 
أثر برنامج إثرائي قائم على معايير العلوم للجيل القادم (NGSS) في تنمية مهارات القرن الحادي والعشرين ونزء ات التفكير لاى طلاب الصف الثالث المتوسط المتفوقين ذوي المستويات المختلفة في معالجة المعلومات

(r') صلاح الدين محمد حسيني، (19 • rم)، استخدام أسلوب الجودة الثاملة لتفعيل دور الجامعة في تعزيز الانتماء لدى الطلاب بمصر، مجلة كلية التربية، بنها، العدد ع، رقمب،

$$
\begin{aligned}
& \text { ص }
\end{aligned}
$$

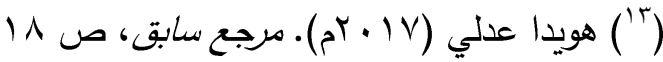

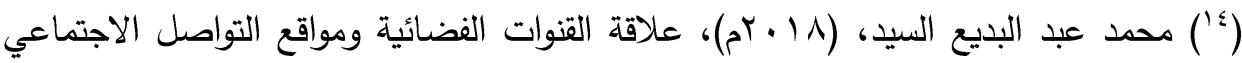

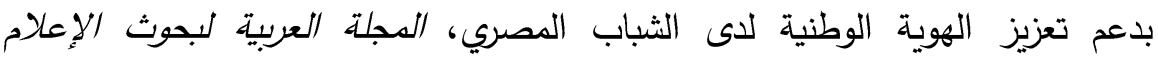

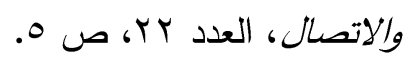

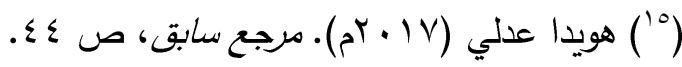

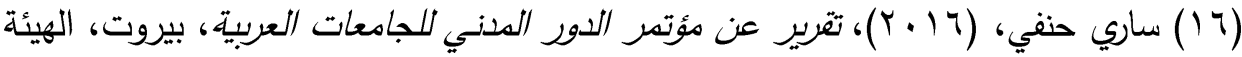

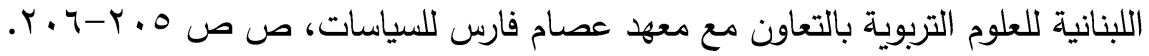

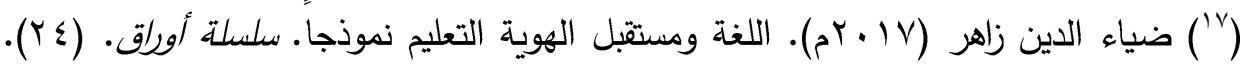
جامعة الإسكندرية، وحدة الدراسات المستقبلية، ص 9 س.

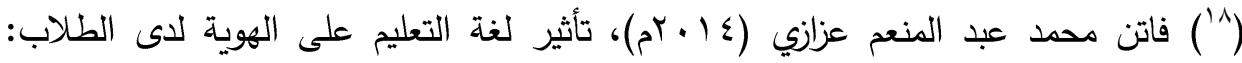

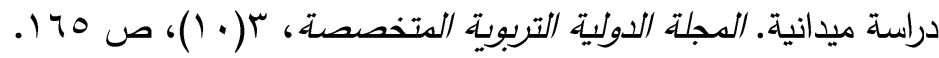

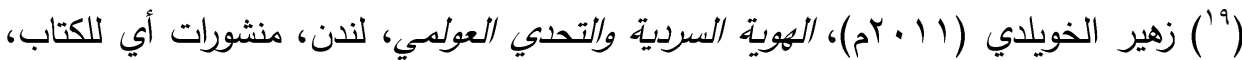

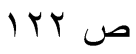

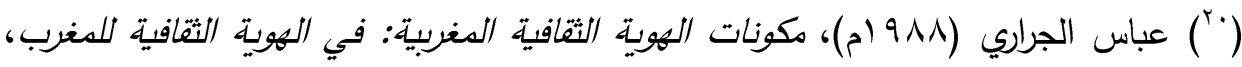

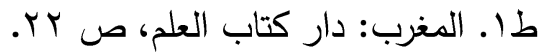

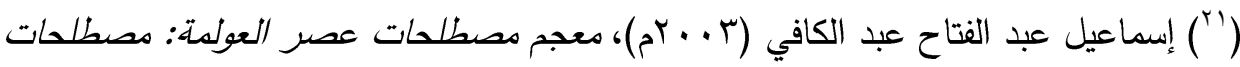
سياسية واقتصادية واجتماعية ونفسية وإعلامية، ص ع ؟

(22) Olson, Eric T. (2002) "Identity". Stanford Encyclopedia of Philosophy. U.S.A. Stanford University, Center for the Study of Language and Information. P. 262

(23) Edgar. E. Borgatta, Rhonda J.V. Monlogomery (2000). Encyclopedia of Sociology. 2nd Edition. New York: MacMillan Reference. Vol. 1. P. 3 


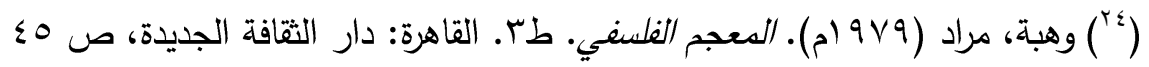
(

((1999). The Liebhart, K. Reisigl, M., \& De Cillia, R., Wodak, R., 26) discursive Construction of National Identity. Edinburgh, United Kingdom: Edinburgh University Press. P. 22.

("National Identity". Lexico.com: UK Dictionary (2020). LEXICO: 27) Oxford English and Spanish Dictionary, Thesaurus, and Spanish to English Translator. Retrieved August 04, 2020 from Lexcio.com https://www.lexico.com/definition/national_identity

(^) عبد الغني عبود، (.99 (1)، الأيلوجيا والتتربية: مدخل لدراسة التربية الدقارنة، القاهرة،

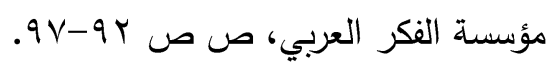

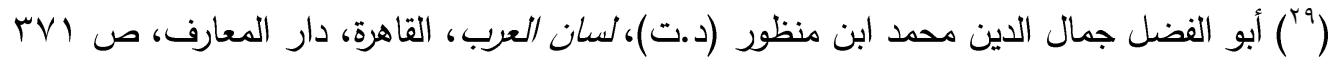

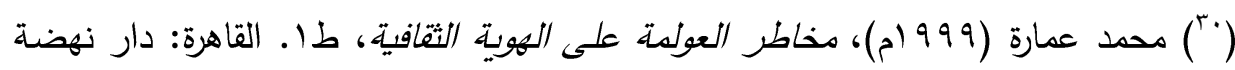

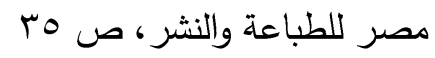

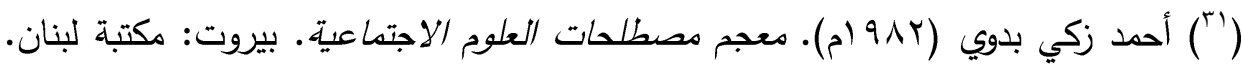

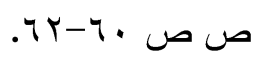

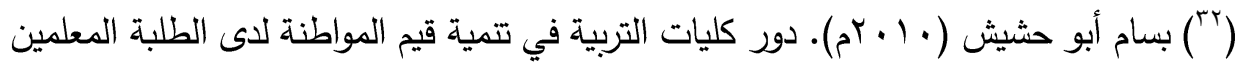

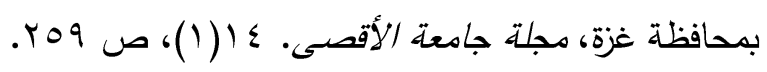

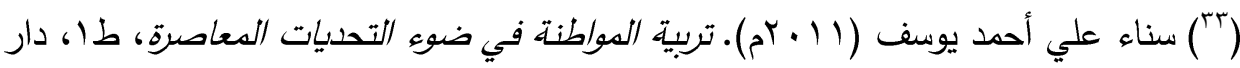

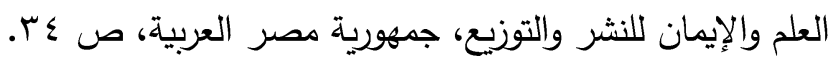

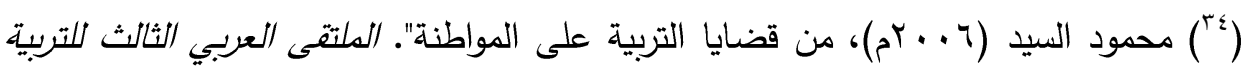

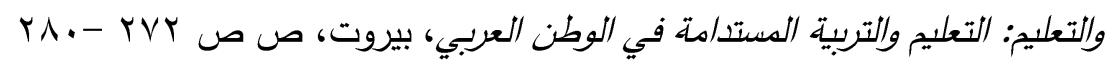

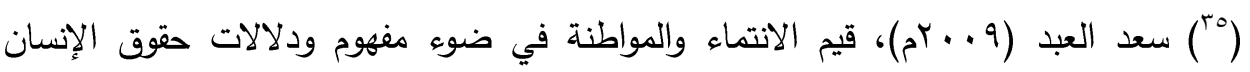

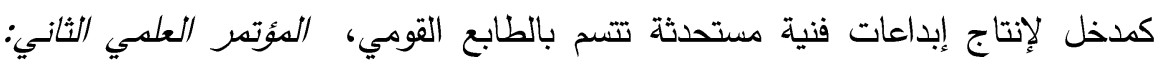

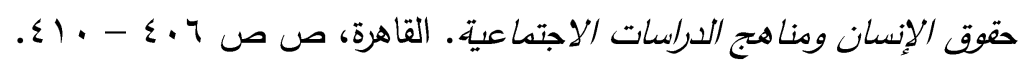

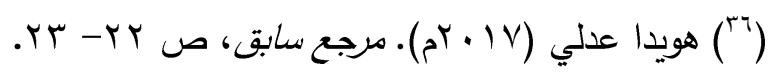

("Op.Cit.: Oxford English and Spanish 37)

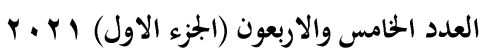

$(423)$
مجلة كلية التربية- جامعة عين شمس 
أثر برنامج إثرائي قائم على معايير العلوم للجيل القادم (NGSS) في تنمية مهارات القرن الحادي والعشرين ونزء ات التفكير لاى طلاب الصف الثالث المتوسط المتفوقين ذوي المستويات المختلفة في معالجة المعلومات

(ncyclopedia of the Social Sciences. , nal E38)

(Peabody Dean (1985). National Characteristics. University of 39) Cambridge, p.419

(Raffiuddin in the Problem of National Character of Pakistan (1963). 40) Pakistan Philosophical Congress, p.12

(dea of nationalism. New York: Macmillan, Hans Kohn (1952). The i41) p.2.

(The Role of Knowledge Almeida, H., \& Sequeira, B. (2019).42)

Transfer in Open Innovation. IGI Global. P. 266.

(Jourdain, K., \& Oiry, E. -Bondarouk, T., Ruel, H., Guiderdoni43)

(2009). Handbook of Research on E-Transformation and Human

Resources Management Technologies: Organizational Outcomes and

Challenges. IGI Global. P. 200.

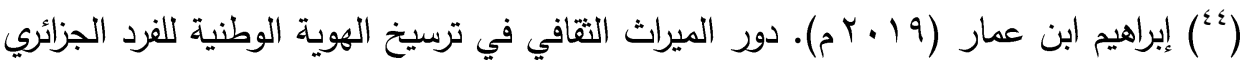

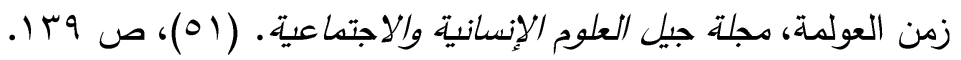

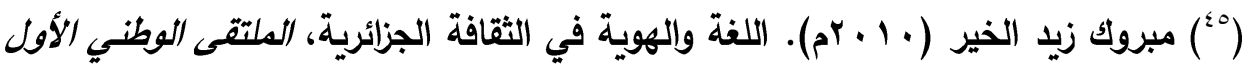

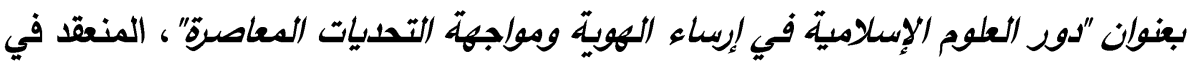

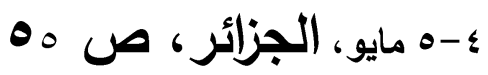

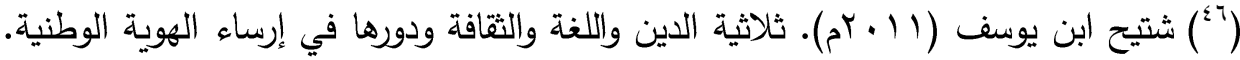

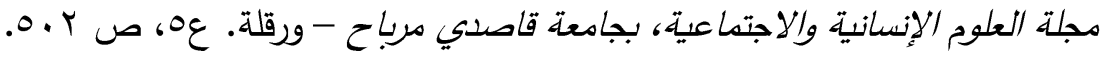

(47) Anderson, B. (1983). Op. Cit. P. 133.

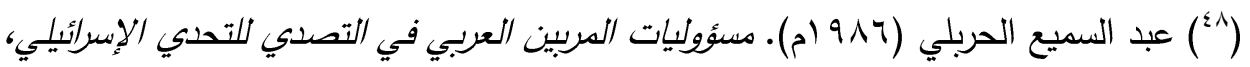

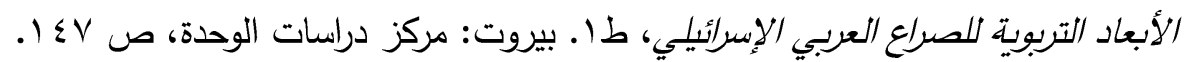

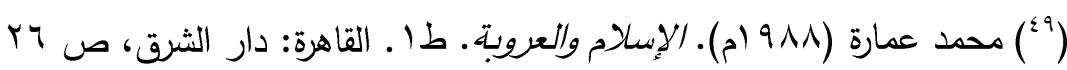

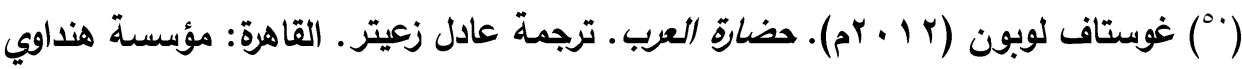

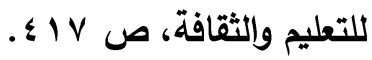

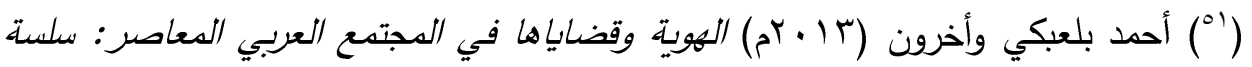
كتب المستقبل العربي ل71، طا ا. بيروت مركز دراسات الوحدة العربية، ص له 109.

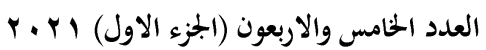

(424)

مجلة كلية التربية- جامعة عين شمس 
( (") ساطع الحصري (910 ام). آراء ودراسات في الفكر القومي. الكويت: كتاب العبي. العدد

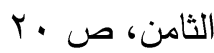

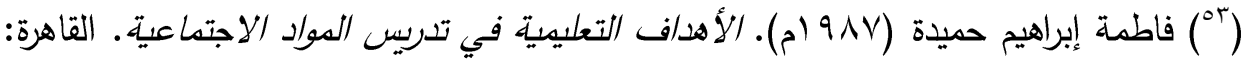

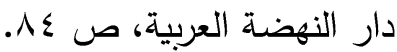

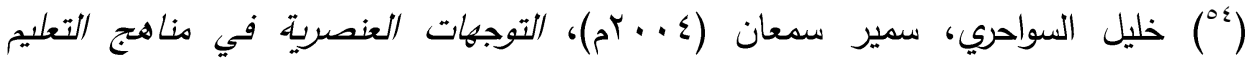
الإسرائيلية. دمشق، منشورات اتحاد الكتاب العرب، ص عـ عـ.

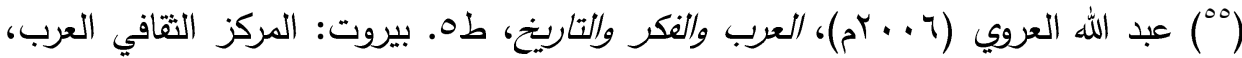
ص 1.0

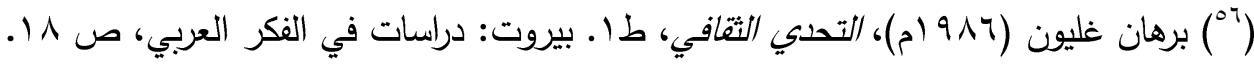

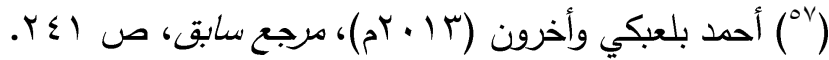

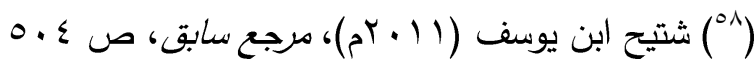

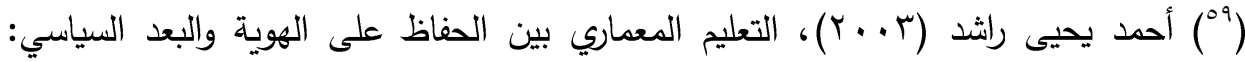
دراسة لمساق تاريخ ونظريات العمارة منذ بدأ الحضارات الإنسانية وحتى عصر العولمة.

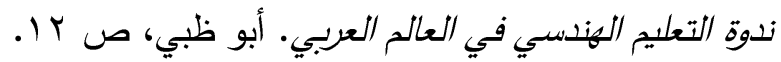

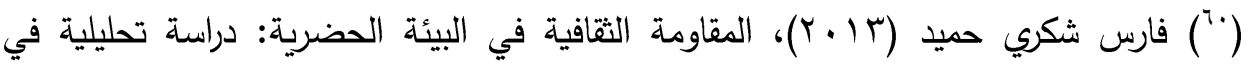
تحولات الهوية العمرانية، دار البيروني للنشر والتوزيع، بيروت، ص 00.

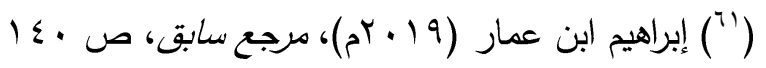

( ${ }^{62}$ ) Matsuda, Noritada (2014). Can Universities Supply Citizenship Education? A Theoretical Insight. Japanese Political Science Review, (2), p. 90.

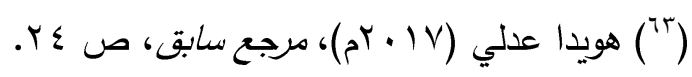

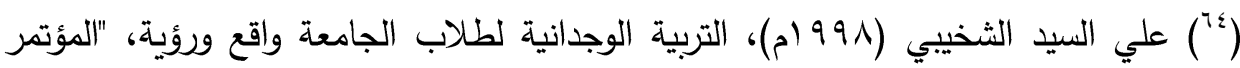
القومي السنوي الحادي عشر - التعليم الجامعي العربي آفاق الإصلاح والتطوير"، القاهرة، لتهيه مركز تطوير التعليم الجامعي. ص هبr. 
أثر برنامج إثرائي قائم على معايير العلوم للجيل القادم (NGSS) في تنمية مهارات القرن الحادي والعشرين ونزء ات التفكير لاى طلاب الصف الثالث المتوسط المتفوقين ذوي المستويات المختلفة في معالجة المعلومات

("70) عبد الله عبد الخالق (999 (م)، العولمة جذورها وفروعها وكيفية التعامل معها. مجلة عالم

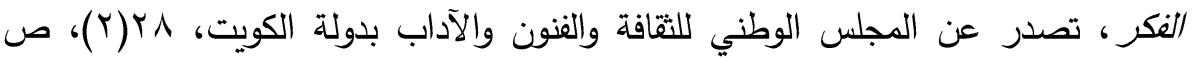
$.0 Y$

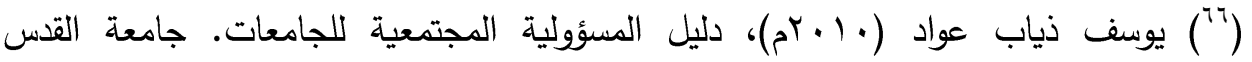
المفتوحة، فلسطين، ص 9.

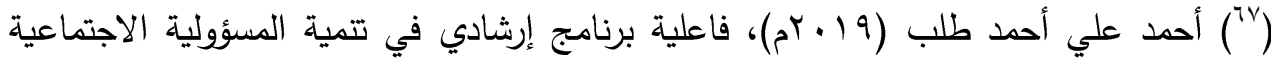
وتعزيز قيم المواطنة لدى طلاب الجامعة. مجلة كلية التربية جامعة سوهاج، ج هوه، ص 17 ه 1.

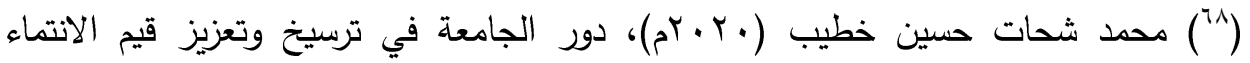

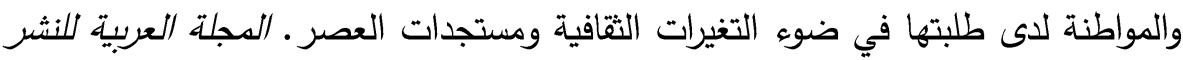

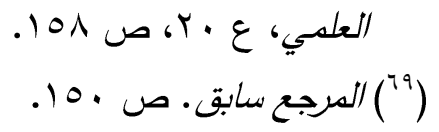
( •) صالح درويش حسن معمار (0 ( . rم)، تربية المواطن وغرس ثقافة المجتمع المدني. مجلة

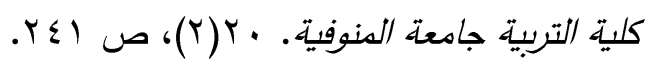

$\left(^{71}\right)$ Marcellin Nkenlifack and Others, (2018), An Approach for Teaching of National Languages and Cultures through ICT in Cameroon, International Journal of Advanced Computer Science and Applications. Vol.2, No. 7. , P.P. 134-135.

(72) United Nations (2018). Language Rights of Linguistic Minorities: A Practical Guide for Implementation, Switzerland, United Nations Special Rapporteur on Minority Issues, P.P.7-10.

(73) Tom Moring and Others (2017). Language Policies in Universities and their Outcomes. U.S.A, Benjamins Publishing Company, P.302.

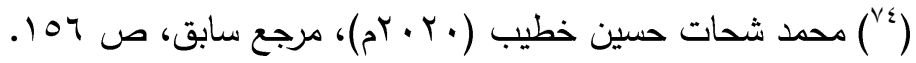

(75) Losito, Bruno (2003) Civic Education in Italy: intended curriculum and students' opportunity to learn. P. 3 of 15 Available: https://www.researchgate.net/publication/238744596_Civic_Educati on_in_Italy_Intended_Curriculum_and_Students'_Opportunity_to_Le arn citations access date 8/10/2019 
(76) Naval et al. (2003). Civic Education in Spain: A Critical Review of Policy. Available: https://www.researchgate.net/publication/242233430_Civic_Educati on_in_Spain_A_Critical_Review_of_Policy/citations access date $8 / 10 / 2019$

(77) Benbin, Liang (2015). English's Influence on the cultural identity of Chinese people in the context of Globalization, Cross Cultural Community. 11(12), p. 27.

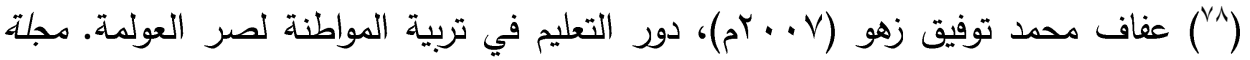

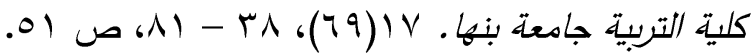

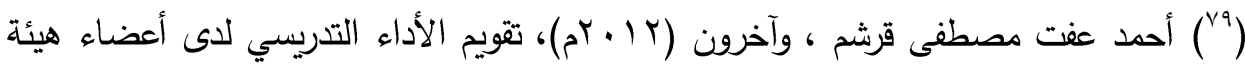
التدريس بجامعة الطائف في ضوه معايير جودة الأداء. مجلة دراسات عربية في التربية.

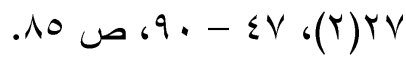

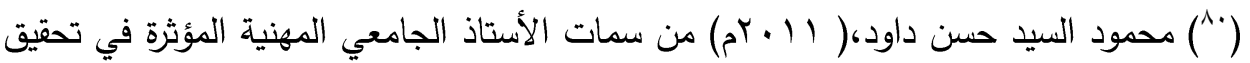
مبدأ الوسطية. مؤتمر دور الجامعات العربية في تعزيز مبدأ الوسطية ببين الثباب العربي.

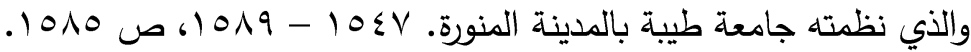

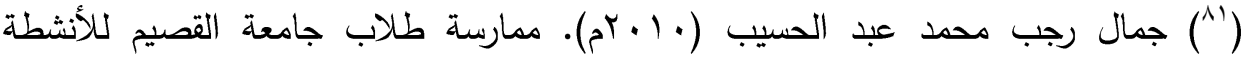

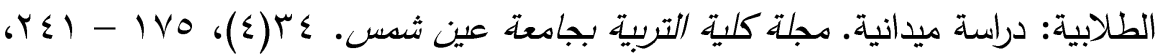

$$
\text { ص ص }
$$

(82) German Lian (2003). Learning to Teach Citizenship in the Secondary Education. London. Routledge Falmer.

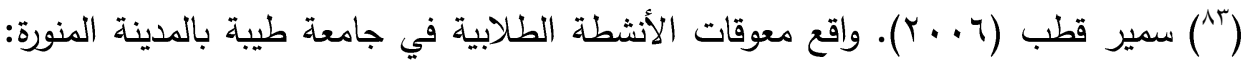

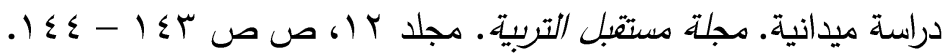

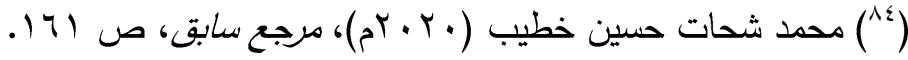

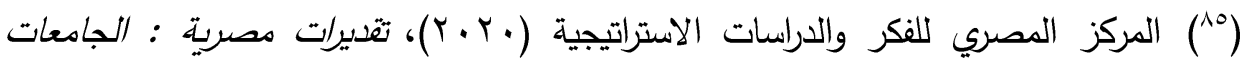

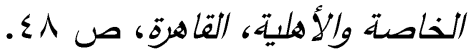

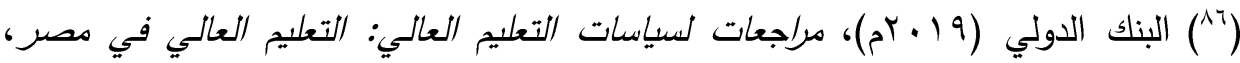

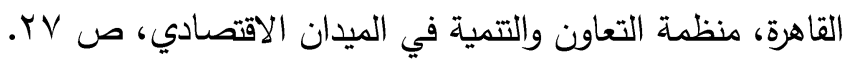


أثر برنامج إثرائي قائم على معايير العلوم للجيل القادم (NGSS) في تنمية مهارات القرن الحادي والعشرين ونزء ات التفكير لاى طلاب الصف الثالث المتوسط المتفوقين ذوي المستويات المختلفة في معالجة المعلومات

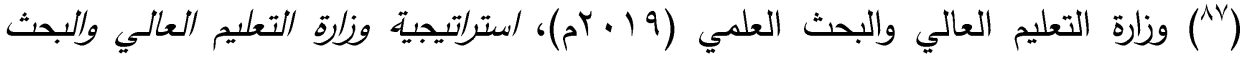

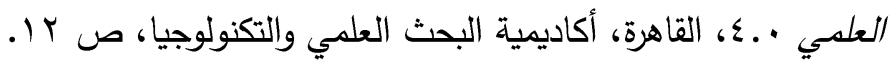

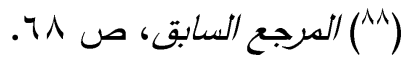

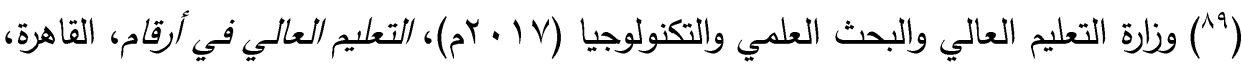

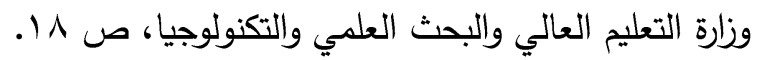

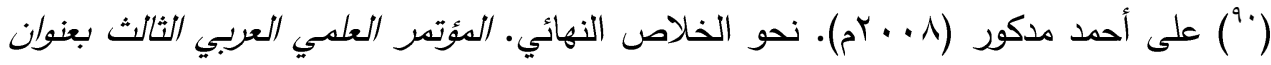

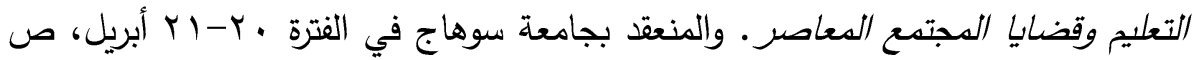

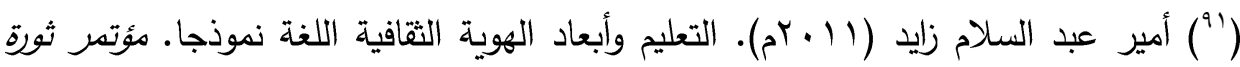

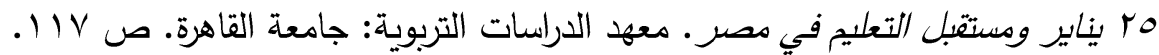

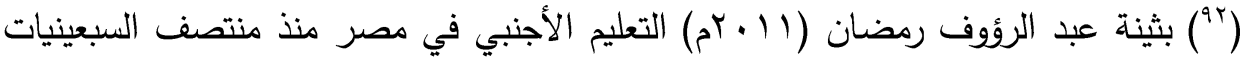
من القرن العشرين حتى قيام ثورة ب يناير ـ مؤتمر ثورة يناير ومستقبل التعليم في مصر.

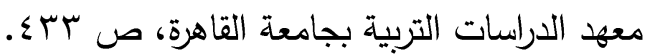

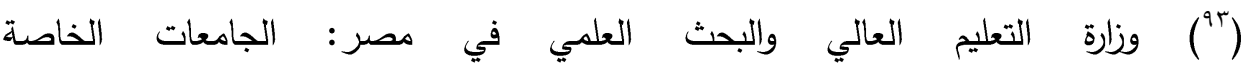
access date ‘ http://portal.mohesr.gov.eg/ar-eg/Pages/private-universities.aspx

$22 / 06 / 2020$

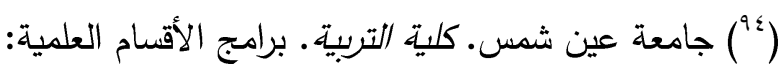

access date 22/06/2020 http://edu.asu.edu.eg/index.php/2010/04/22/scientific_d/ كلية الحقوق. قطاع التعليم والطلاب: شعبة الإنجليزي، الثعبة الفرنسية،

access http://law.asu.edu.eg/article.php?action=show\&id=5665\#.X0V3Ysj7TIU

date $25 / 06 / 2020$

كلية التجارة الصفحة الرسمية للكلية على شبكة الانترنت: access date 25/06/2020 http://newcommerce.asu.edu.eg/new/

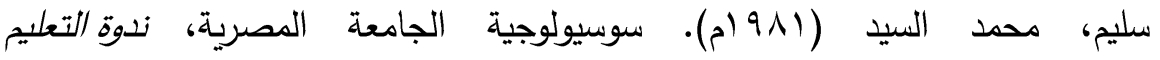

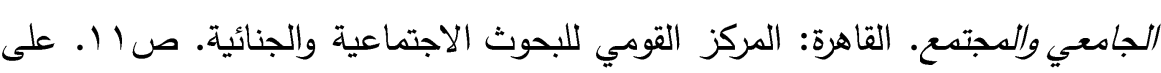
access http://www.egyptclub.de/Studium-in-Fremdsprache.htm الرابط التالي: date $25 / 06 / 2020$

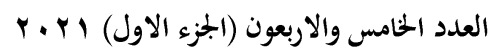

(428)
مجلة كلية التربية- جامعة عين شمس 


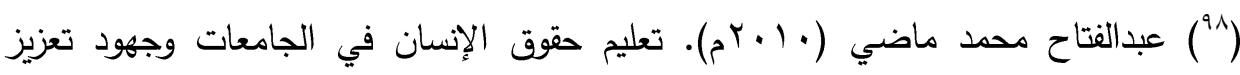

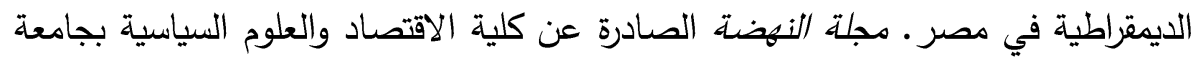

$$
\begin{aligned}
& \text { القاهرة. } 1 \text { (Y)( ص } 7 .
\end{aligned}
$$

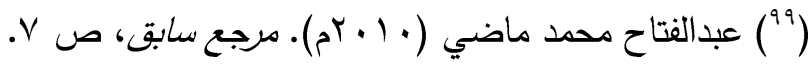

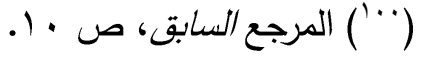

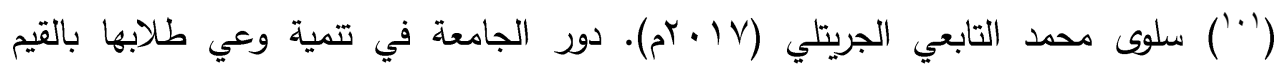

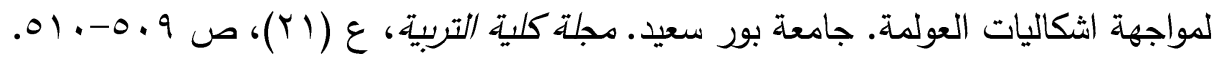

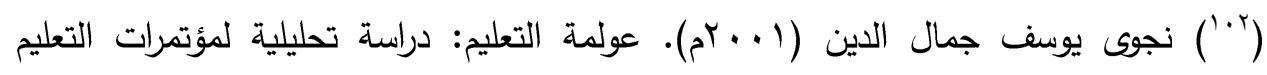

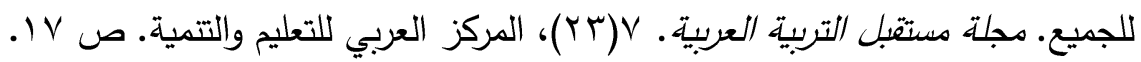

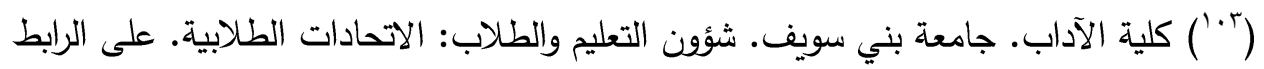
التالي: - - n

r\&cat_id=rr/9http://www.arts.bsu.edu.eg/Content.aspx?section_id=

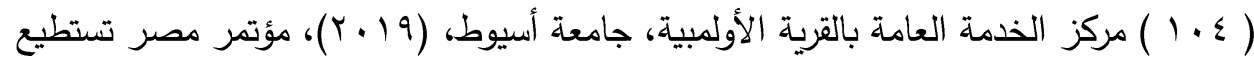
Available http: www.aun.edu.eg Accessed (20-3-2021)، بطلابها، 9 ( r)

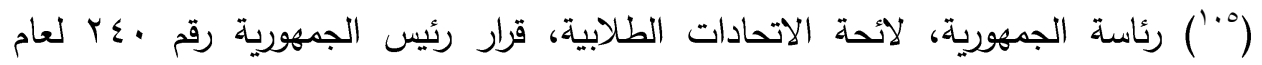

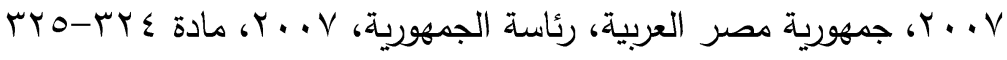

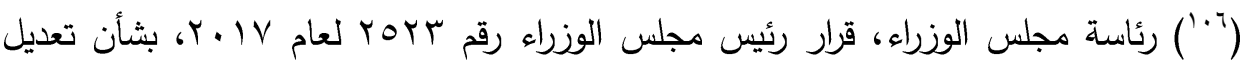

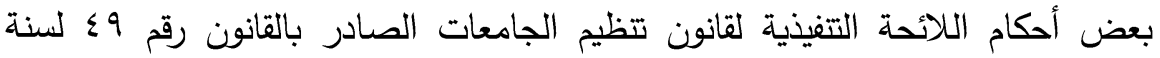

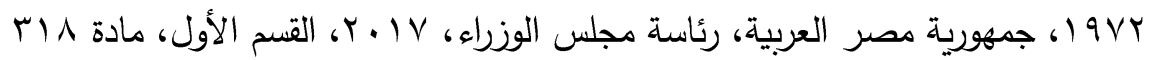

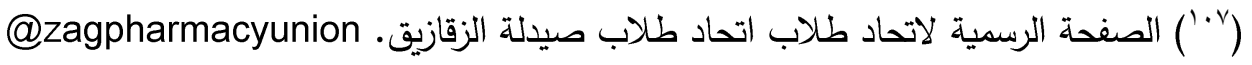

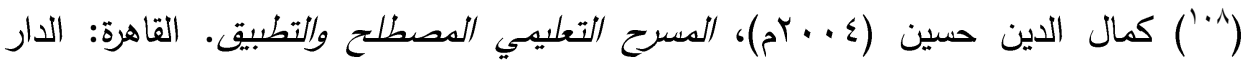

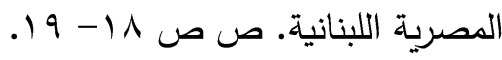


أثر برنامج إثرائي قائم على معايير العلوم للجيل القادم (NGSS) في تنمية مهارات القرن الحادي والعشرين ونزء ات التفكير لاى طلاب الصف الثالث المتوسط المتفوقين ذوي المستويات المختلفة في معالجة المعلومات

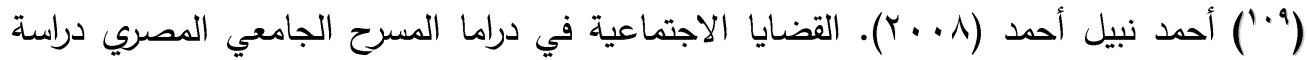
تحليلية وميدانية. رسالة دكتوراه غير منشورة. مقدمة إلى كلية التربية النوعية، جامعة عين شمس، الاعاعل

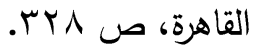

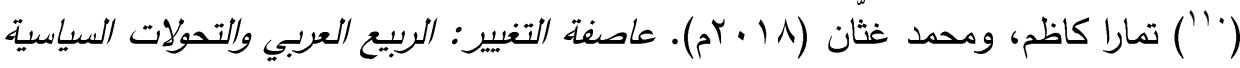
في الدنطقة العببية. طا. برلين: المركز الديمقراطي العربي، ص و V9.

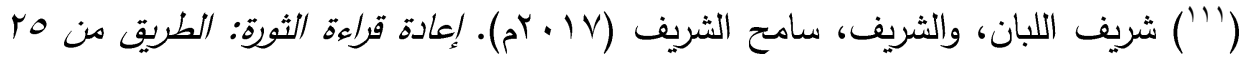

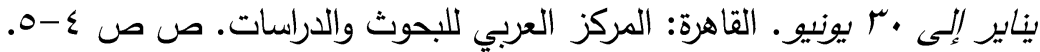

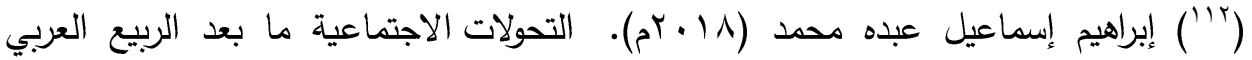
وانعكاساتها على الثباب من منظور علم الاجتماع السياسي: دراسة حالة مصر خلال

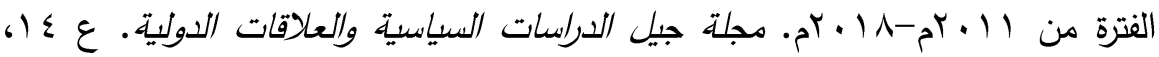
ص ص n n

$\left.{ }^{113}\right)$ Greenwalt, K. A. (2009). Discourse, Narrative, and National Identity: The Case of France. Harvard Educational Review, 79(3), 494519,539. P. 500.

$\left.{ }^{114}\right)$ Simon, Patrick (2012). French National Identity and Integration: Who Belongs to the National Community? A Project of Migration Policy Institute. Paris. P. 7-9.

$\left({ }^{115}\right)$ Alla Petrivna Durdas, (2018), Higher Education in France: Historical Development, The Modern Higher Education Review, No. 3, P. 29.

$\left.{ }^{116}\right)$ Catherine Paradeise (2017). Higher Education System and Institution: France, Encyclopedia of International Higher Education Systems and Institutions, Dordrecht, Springer Science, P. 359.

$\left({ }^{117}\right)$ Choose France to Study and Live , Campus France, Available: http:// www.campusfranceparis, Accessed (7-3-2021)

(118) Gordon, Philip H. \& Meunier Sophie (2001). Globalization and French Cultural Identity. French Politics. Culture \& Society, 19(1). P. 36

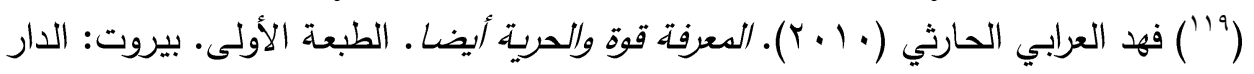
العربية للعلوم ناشرون. ص 9 •.1. 
(120) The French National Assembly: Constitution of October 1958 (1960). Paris: The French National Assembly. Article 87

(121) French Embassy. Official Website of the Cultural Service of the French Embassy: The Teaching Assistant Program in France, Available:

http://www.transitionsabroad.com/listings/work/esl/france.shtml.

(Accessed: 18-2-2020)

(122) Moloney Robyn. (2008). I Speak Therefore I am Self-Perceptions of Identity in Immersion Program Language Learners as an Expression of Intercultural Competence. University of Sydney Papers in TESOL. P. 122- 123.

(123) University and Master Study in France, A Guide for 2021, Available: https://www.findamasters.com/studyabroad/europe/masters-study-in-france.aspx, Accessed (7-1-2021)

(124) Yale University, Open Yale Course, Lecture 4: A Nation? Peasants, Language, and French Identity, Available: https://oyc.yale.edu/history/hist-276/lecture-4, Accessed (7-1-2021)

(125) Osler \& H. Starkey (2009). Citizenship Education in France and England: contrasting approaches to national identity and diversity IN BANKS, J. A. (Ed.). The Routledge International Companion to Multicultural Education. New York, Routledge. P. 13.

(126) A. OSLER, H. STARKEY, (2009), Citizenship Education in France and England: Contrasting Approaches to National Identity and Diversity, in BANKS, J. A. (Ed.) The Routledge International Companion to Multicultural Education. New York, Routledge. P. 21.

(127) MARSEILLE MARSEILLE ET AIX-EN-PROVENCE, Main Program of Study, Available: https://ressources.campusfrance.org/pratique/etablissements/en/univ_ aix_en.pdf, Accessed: (7-1-2021)

(128) Institut Catholique LYON, Students Guide for Programs, Available:

https://ressources.campusfrance.org/pratique/etablissements/en/instit ut_catholyon_en.pdf, Accessed: (7-1-2021)

(129) Paris University, Students Guide, Available: https://ressources.campusfrance.org/pratique/etablissements/en/univ_ paris10_en.pdf, Accessed : (7-1-2021) 
أثر برنامج إثرائي قائم على معايير العلوم للجيل القادم (NGSS) في تنمية مهارات القرن الحادي والعشرين

ونزء ات التفكير لاى طلاب الصف الثالث المتوسط المتفوقين ذوي المستويات المختلفة في معالجة المعلومات

(130) National Institution for the Academic Degrees and University Evaluation $(r \cdot 1 r)$. Overview: Quality Assurance System in Higher Education. France. P. $24-25$.

(131) European Students' Union (2008). The Student Union Development Handbook for a Stronger Students Movement. Berlin: Council of Europe. P. 17- 22.

(132) Changemakers Academy Project, Student Councils in France, Available: https://www.obessu.org/what-we-do/projects-2/currentprojects/european-changemakers-academy-ecma/, Accessed: (7-12021)

(133) Stronger Students Union Project, Available: https://www.obessu.org/what-we-do/projects-2/currentprojects/stronger-school-student-unions-sssu/, Accessed (7-1-2021)

(134) Migrants in Higher Education, The Network of French Institutions, Available: https://www.campusfrance.org/en/migrants-highereducation-french-education-network, Accessed: (7-1-2021)

(135) The French Constitution, (1958), concerning French Speaking World and on the Association Agreement, article 87.

(136) Benjamin Sawe (2019). "Ethnic Groups and Demographics of France". https://www.worldatlas.com/articles/what-is-the-ethniccomposition-of-france.html . Accessed: 2-2-2021.

(137) Joan Palmiter , (2017), French Language Acquisition: Reflection on the French Language, Acculturation and Identity, French Honors Thesis, University of Washington, P.11.

(138) Andrew Knapp\& Vincent Wright, 2016, The Government and Politics of France, Fifth Edition, London, Routledge Taylors and Francis Group, P.P.10-11.

(139) Eckstein, Andrew J. (1999). Japan's National Identity: Nationalists or Not?" Seminar in Lehigh University about International Relations, U.S.A. p. 4.

(140) Higher Education Burea, (2016). Higher Education in Japan. Tokyo, Ministry of Education. Culture, Sports, Science, and Technology, P.4. 
(141) Setsuo Arikawa (2019). Universities in Japan: Supporting Excellence. Japan Committee of Universities for International Exchange, P.P. 5, 7.

(142) Independent Administrative Institution, (2020). Student Guide to Japan 2019-2020), Tokyo, Japan Student Service Organization, P.24.

(143) Turnbull, Blake (2017). Learner perspectives on national identity and EFL education in japan: Report of a questionnaire study. Journal of Asia TEFL, 14(2), 211-227. P. 213 - 215

(144) Nishino, T., \& Watanabe, M. (2008). Communication-oriented policies versus classroom realities in Japan. TESOL Quarterly, 42(1), $133-138$

(145) Turnbull, Blake. (2017). Op. Cit. P. 212.

(146) WASEDA BK Japanese Language Course, Tokyo, Available: https://www.dreamstudiesabroad.com/schools/waseda, Accessed: ( 81-2021)

(147) Genki Japanese and Culture School, Available: https://www.dreamstudiesabroad.com/schools/genkijacsm Accessed: (8-1-2021)

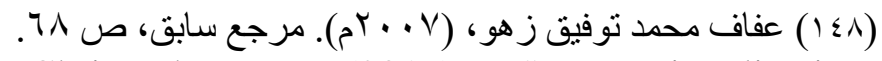

(149) Hammond, Christopher D. (2017). "Internationalization, Nationalism, and Global Competitiveness: A Comparison of Approaches to Higher Education in China and Japan". Asia Pacific Educational Review. 17(4). P.P.565-567.

(150) Yamanashi Gakuin University, Available: https://www.dreamstudiesabroad.com/schools/yamanashi, Accessed (8-1-2021)

(151) Faculty of Education and Human Studies- Akita University, Course for Compulsory School Teachers, Available: https://www.akitau.ac.jp/eduhuman/english/department/dept_edu01.html, Accessed (8-1-2021)

( 10 r) Kyoto University (2014). Getting to Know the Many Facts about Japan. Kyoto University. Research University Activities. P. 3-5.

(153) Faculty of Education and Human Studies- Akita University, About Nursing Care Experience - Cultivation of a Rich Humanity, As a Teacher and As a Human, Available: https://www.akita- 
أثر برنامج إثرائي قائم على معايير العلوم للجيل القادم (NGSS) في تنمية مهارات القرن الحادي والعشرين ونزء ات التفكير لاى طلاب الصف الثالث المتوسط المتفوقين ذوي المستويات المختلفة في معالجة المعلومات

u.ac.jp/eduhuman/english/department/dept_practice02.html, Accessed (8-1-2021)

(154) Hiroshima University, (2020), Multicultural Understanding, An Online Conference that held on 28 September 2020, Center for Diversity and Inclusion, Cover Page.

(155) Ministry of Foreign Affairs, (2018), Sea Of Japan, Tokyo, P.4.

(156) Turnbull, Blake. (2017). Op. Cit. P. 212.

(157) Takeshi Ishida. (1971). Japanese Society. New York: London House. P. 32.

(158) Sasaki, Miyuki (2008). "The 150 Years History of English

Language Assessment in Japanese Education". In Language Testing Review. 25(1), SAGE Publications. P. 69.

(159) Ministry of Foreign Affairs (1985). The Japan of Today. Tokyo. P. 19.

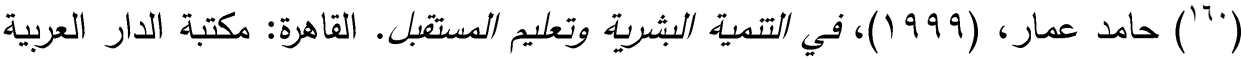

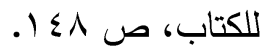

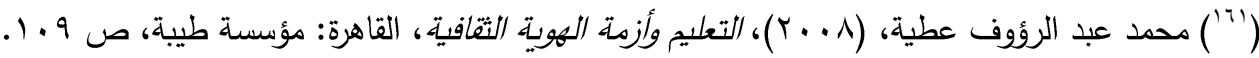

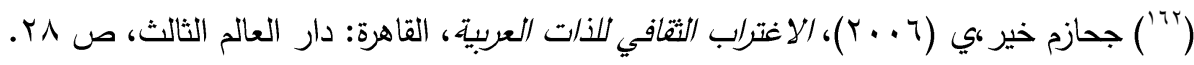

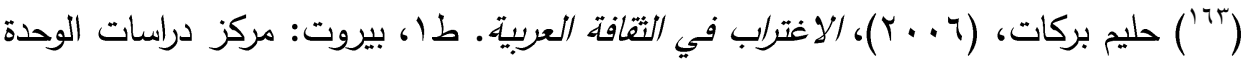

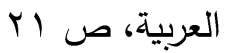

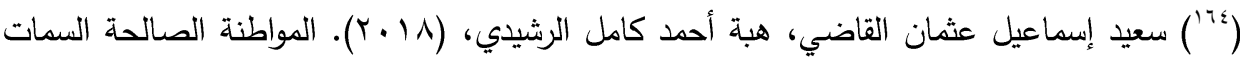

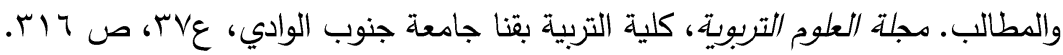

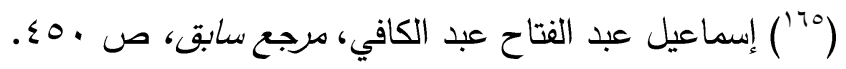

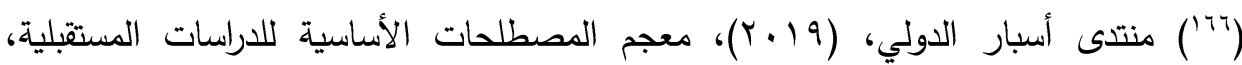

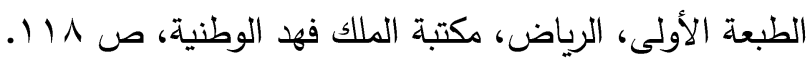

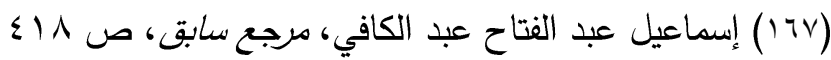

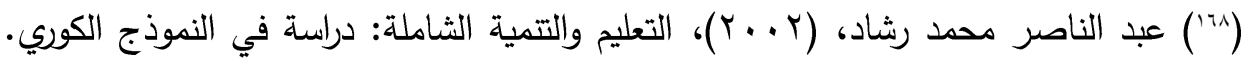

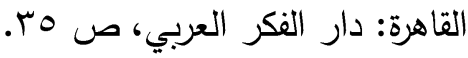




\section{د. يحيى مصطفى كمال الدين د. ولاء السيد عبد الله السيد صقر}

(799) أحمد زكي بدوي، (ع/911). معجم مصطلحات العلوم الإدارية. القاهرة: دار الكتاب

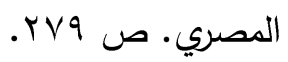

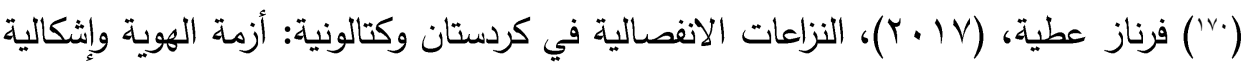

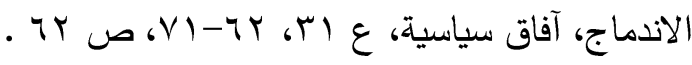


أثر برنامج إثرائي قائم على معايير العلوم للجيل القادم (NGSS) في تنمية مهارات القرن الحادي والعشرين ونزء ات التفكير لدى طلاب الصف الثالث المتوسط المتفوقين ذوي المستويات المختلفة في معالجة المعلومات 